ESTUDIO

\title{
COMENTARIO CRÍTICO A LA REGULACIÓN DE LOS DELITOS CONTRA EL MEDIO AMBIENTE EN EL ANTEPROYECTO DE CÓDIGO PENAL DE 2005*
}

\author{
Antonio Bascuñán Rodríguez
}

\begin{abstract}
El autor realiza un examen crítico de la regulación sobre delitos relativos al medio ambiente contenida en el Anteproyecto de Código Penal del Ministerio de Justicia de 2005. Para tal efecto formula primero consideraciones generales en relación con el objeto de protección y los modos de ataque en los delitos medioambientales y en relación con la dependencia en que se encuentra el derecho penal respecto del derecho administrativo en la configuración de estos delitos. Luego examina críticamente las normas sobre delitos en particular previstas por el anteproyecto, así como las reglas generales sobre autoría, relevancia de las autorizaciones administrativas ilegales y penas a las personas jurídicas. El resultado de este examen, claramente negativo para el anteproyecto, es finalmente resumido a modo de conclusión.
\end{abstract}

Antonio Bascuñán. Abogado. Profesor de Teoría del Derecho y Derecho Penal, Universidad Adolfo Ibáñez y Universidad de Chile.

* El autor agradece a los estudiantes de la Facultad de Derecho de la Universidad Adolfo Ibáñez, Bernardo Busel Niedmann y Manuel González González por la ayuda prestada en la revisión y edición del presente trabajo.

Véanse también en esta edición los artículos "Derecho Penal Medioambiental: ¿Porqué o cómo?”, de Roland Hefendehl, y “Fundamentos de la Propuesta de la Comisión Foro Penal para la Protección del Medio Ambiente”, de Jean Pierre Matus A. (N. del E.)

Estudios Públicos, 110 (otoño 2008). 


\section{Planteamiento general}

$\amalg_{1 \text { propósito de este trabajo es ofrecer un comentario crítico a los }}$ artículos 167 a 173 y a algunos de los Arts. 228 a 233 del anteproyecto de nuevo código penal (en adelante, "el anteproyecto” o “AP”), que fuera elaborado por una comisión de expertos reunidos por el Ministerio de Justicia durante los años 2003 y 2005․ Las disposiciones del primer grupo mencionado regulan los "delitos relativos al medio ambiente" del anteproyecto, comprendidos en el párrafo primero del título noveno de su libro segundo; el segundo grupo corresponde a las disposiciones comunes a los distintos grupos de delitos que integran dicho título. Ambos grupos de disposiciones tienen su origen en un proyecto de ley sobre delitos contra el medio ambiente que fuera elaborado en el marco de un proyecto de investigación realizado por un grupo de investigadores de la Universidad de Talca, bajo la dirección de Jean Pierre Matus (en adelante "el proyecto”, o “P”)2.

Aunque en la redacción de uno y otro texto son constatables diferencias, la similitud general justifica comentarlos conjuntamente, considerando el anteproyecto como una versión revisada del proyecto. La fundamentación de éste ofrece el marco general de referencia de la crítica a aquél. Por otra parte, dado que el proyecto se presenta como la versión chilena del modelo estándar de codificación europeo-continental de la protección penal del medio ambiente, su evaluación exige considerar algunos antecedentes de derecho penal comparado ${ }^{3}$.

${ }^{1}$ Ministerio de Justicia (Comisión Foro Penal): “Anteproyecto de Nuevo Código Penal. Texto refundido y sistematizado del articulado aprobado en las deliberaciones de la Comisión Foro Penal, desde el 8 de mayo de 2003 hasta el 10 de noviembre de 2005. Elaborado por Jean Pierre Matus Acuña y Héctor Hernández Basualto”, noviembre de 2005 (ejemplar electrónico de 78 páginas, inédito.)

${ }^{2}$ Matus Acuña, Jean Pierre (ed.): Derecho Penal del Medio Ambiente. Estudios y Propuesta para un Nuevo Derecho Penal Ambiental Chileno, 2004. Con anterioridad, el proyecto de investigación generó otras dos publicaciones: Matus Acuña, Jean Pierre, Marcos Orellana Cruz, Marcelo Castillo Sánchez, María Cecilia Ramírez Guzmán: “Análisis Dogmático del Derecho Penal Ambiental Chileno a la Luz del Derecho Comparado y las Obligaciones Contraídas por Chile en el Ámbito del Derecho Internacional. Conclusiones y Propuesta Legislativa Fundada para una Nueva Protección Penal del Medio Ambiente en Chile”, 2003, p. 11; Matus A., Jean Pierre, María Cecilia Ramírez G., Marcelo Castillo: "Informe sobre el Derecho Penal Ambiental en el Derecho Comparado de Tradición Continental”, 2002, p. 7.

${ }^{3}$ A este respecto priorizo la consideración del Código Penal alemán (§§ 324-330a) y del Código Penal español (Arts. 325-331). Sobre el derecho penal alemán del medio ambiente: en general, Ransiek, Andreas: "Comentario a los §§ 324-330-a StGB”, 2005, Tomo II, p. 5592; Steindorf, Joachim: “Observación Preliminar a los §§ 324-330-a StGB”, 2005; para aspectos particulares, especialmente la evolución entre 1980 y 1994, Rudolphi, Hans-Joachim: “Primat des Strafrechts im Umweltschutz?” (¿Primado del derecho penal en la protección del medio ambiente?), 1984, p. 193; Tiedemann, Klaus, Urs 
Lejos de proponer una concepción de la función del derecho penal del medio ambiente radicalmente distinta de la tenida a la vista por el anteproyecto — en rigor, por el proyecto—- este comentario asume más bien la forma de una crítica interna. Mi tesis es simple: el anteproyecto acierta en la identificación de las cuestiones que hacen problemática la regulación de los

Kindhäuser: "Umweltstrafrecht. Bewährung oder Reform?” (Derecho penal del medio ambiente. ¿Conservación o reforma?”), 1988, p. 337; Rengier, Rudolf: “Zur Bestimmung und Bedeutung der Rechtsgüter im Umweltstrafrecht” (Acerca de la determinación y significado de los bienes jurídicos en el derecho penal del medio ambiente), 1990, p. 2506; Otto, Harro: "Grundsäztliche Problemstellungen des Umweltstrafrechts" (Problemas fundamentales del derecho penal del medio ambiente), 1991, p. 308; Kuhlen, Lothar: "Umweltstrafrecht - auf der Suche nach einer neuen Dogmatik" (Derecho penal del medio ambiente - a la búsqueda de una nueva dogmática), 1993, p. 697; Otto, Harro: "Das neue Umweltsstrafrecht" (El nuevo derecho penal del medio ambiente), 1995, p. 134; Schünemann, Bernd: "Zur Dogmatik und Kriminalpolitik des Umweltstrafrechts" (Sobre la dogmática y la política criminal del derecho penal del medio ambiente), 1996, p. 437 s. (versión en español en Schünemann, Bernd: Temas Actuales y Permanentes del Derecho Penal después del Milenio, Editorial Tecnos, Madrid, 2002, p. 203 s.); Bloy, René: “Umweltstrafrecht: Geschichte. Dogmatik. Zukunftsperspektiven” (Derecho penal del medio ambiente: Historia. Dogmática. Perspectivas del futuro), 1997, p. 577. Sobre derecho penal español del medio ambiente: en general, Queralt Jiménez, Joan: Derecho Penal Español. Parte Especial, 2002, p. 623 s., Silva Sánchez, Jesús María: Delitos contra el Medio Ambiente, 1999a; para aspectos particulares: De la Mata Barranco, Norberto: Protección Penal del Medio Ambiente y Accesoriedad Administrativa, 1996; Camilo, Javier, y Sessano Goenaga: "La Protección Penal del Medio Ambiente: Peculiaridades de su Tratamiento Jurídico”, 2002, Alastuey Dobón, María del Carmen: El Delito de Contaminación Ambiental (Art. 325.1 del Código Penal), 2004; y las contribuciones recogidas en Barreiro, Agustín Jorge (director): Estudios sobre la Protección del Medio Ambiente en el Ordenamiento Jurídico Español, 2005. Para un examen de derecho comparado, inclusivo de las regulaciones alemana y española: Faure, M., y M. Visser: "How to Punish Environmental Pollution? Some Reflections on Various Models of Criminalization of Environmental Harm”, 1995; Mendoza Calderón, Silvia: "La Protección Penal del Medio Ambiente en Alemania, Italia, Francia y España: Estudio de Derecho Penal Comparado”, 2005. En lo que respecta al derecho penal del medio ambiente norteamericano, su extrema fragmentariedad lo hace prácticamente inmanejable para los fines de este comentario. No obstante, la discusión académica acerca de la evolución y los problemas del uso del derecho penal para reforzar la legislación medioambiental son directamente pertinentes, como puede apreciarse por ejemplo en Schroeder, Christopher H.: "Cool Analysis Versus Moral Outrage in the Development of Federal Environmental Criminal Law”, 1993; Lazarus, Richard L.: "Assimilating Environmental Protection into Legal Rules and the Problem with Environmental Crime", 1994; el mismo, "Meeting the Demands of Integration in the Evolution of Environmental Law: Reforming Environmental Criminal Law", 1995a; Brickey, Kathleen F.: "Environmental Crime at the Crossroads: The Intersection of Environmental Law Theory", 1996-1997. En todo caso, cabe señalar que la diferencia cultural entre la codificación y el derecho jurisprudencial no es directamente relevante en este ámbito. El derecho del medio ambiente norteamericano es derecho estatutario, en un sentido formal (legislación, regulación administrativa) y político (intervención regulativa estatal deliberada), y no derecho del common law: "Algunos 
delitos contra el medio ambiente, pero yerra en su tratamiento. En otras palabras, las reglas del anteproyecto pueden entenderse como intentos de respuesta a esos problemas, pero en ningún caso son aceptables como soluciones.

En la exposición de esta tesis procederé del siguiente modo. Primero identificaré los ámbitos en que se advierte el carácter problemático el derecho penal del medio ambiente, haciendo referencia a dos aspectos básicos, la identificación del bien jurídico protegido y del ataque en su contra (2) y la dependencia que manifiesta la regulación penal de la regulación administrativa (3). Luego analizaré en general el tratamiento sistemático dado por el anteproyecto a los delitos relativos al medio ambiente (4), para seguir con el análisis de cuestiones más específicas de la configuración de los dos supuestos centrales de los delitos de atentado al medio ambiente (5) y el incierto carácter del tercer supuesto que integra este grupo de delitos (6). Después examinaré brevemente el delito de incumplimiento del sistema de evaluación de impacto ambiental (7) y el delito de manejo de sustancias peligrosas (8). En su calidad de cuestiones comunes a todos los delitos analizaré también críticamente la configuración del ámbito de autoría (9) y el tratamiento de la autorización administrativa (10). Como último aspecto del anteproyecto a comentar, haré un breve comentario acerca de las penas y otras consecuencias coercitivas (11). Finalmente, terminaré mi exposición con la enumeración de ciertas conclusiones a modo de resumen (12).

Antes de proceder del modo anunciado, sin embargo, me parece indispensable una reflexión previa. Es un hecho en verdad extraño que el surgimiento del derecho del medio ambiente en el sistema jurídico chileno $^{4}$ no haya estado acompañado por el surgimiento, ni siquiera embrio-

casos que ahora llamaríamos del medio ambiente fueron llevados a la corte bajo el derecho del common law, lográndose poner remedio a daños por contaminación. El common law, sin embargo, no creó un cuerpo consistente de derecho jurisprudencial que reconociera la amplia legitimidad de la protección al medio ambiente, y a menudo se inclinó en los hechos ante la misión de la industrialización" (Plater, Zygmunt J. B.: "From the Beginning, a Fundamental Shift of Paradigms: A Theory and Short History of Environmental Law”, 1993-1994. De aquí que sea inherentemente inductora a confusión la tematización del derecho ambiental norteamericano como "tradición del common law”, consignada en Matus (ed.), Derecho Penal..., op. cit. supra, nota 2, p. 171).

${ }^{4}$ Me refiero al establecimiento de la Ley 19300, sobre bases generales del medio ambiente (Diario Oficial de 9 de marzo de 1994). Ciertamente, antes de esa ley existía regulación - legal y reglamentaria - relativa a la preservación de los recursos naturales y al tratamiento de emisiones contaminantes, que por lo demás no fue sustituida por la nueva regulación. No obstante, fue la ley 19300 la que confirió a esa regulación un sentido determinado dentro de un modelo de diseño institucional para la actuación estatal orientada a la protección del medio ambiente. Para un vistazo de las normas sancionatorias penales previstas en la regulación preexistente a la Ley 19300, Matus, Orellana, Castillo y Ramírez: “Análisis Dogmático...”, op. cit. supra, nota 2, p. 29 s. 
nario, de un derecho penal del medio ambiente. Dejando de lado la cuestión de la incorporación de las normas punitivas en el contexto sistemáticamente más exigente de la codificación, es decir, desde el solo punto de vista del interés estatal en asegurar coercitivamente la vigencia de su intervención regulativa, resulta difícil de entender la prescindencia de un aparato institucional sancionador suficientemente poderoso en el diseño institucional del derecho del medio ambiente conforme a un modelo de primera generación, es decir, de command-and-control ${ }^{5}$.

En parte, la explicación de este fenómeno pareciera encontrarse en la inexistencia a esa época, previa a la reforma procesal penal, de un órgano público institucionalmente responsable de la realización de las pretensiones punitivas del legislador. La apreciación del viejo procedimiento penal como un mecanismo institucional ineficiente, opaco y en el cual se diluía la responsabilidad pública por la prosecución de la investigación y el proceso, hacía desaconsejable otorgarle un rol relevante en la aplicación coercitiva de la regulación ambiental. En parte también ha de tenerse presente que la inexistencia de sanciones penales a los atentados contra el medio ambiente es congruente con el fenómeno generalizado en el derecho chileno de prescindencia legal de la reacción punitiva frente a acciones característicamente cometidas en el ámbito de la empresa, como la administración desleal societaria y las infracciones a la regulación de la libre competencia. Pero la razón más probable de la inexistencia de un aparato sancionador poderoso parece encontrarse en la debilidad con que la Ley 19300 asumió, en el plano regulativo administrativo, el modelo de command-and-control. Desde el punto de vista sancionatorio administrativo, ese déficit es evidente. Se trata de un diseño institucional de coordinación y no de concentración, que preserva las competencias de fiscalización preexistentes, y que para efectos de la sanción administrativa de las infracciones a la propia Ley 19300 y las normas originadas a partir de ella dispone distintos procedimientos, ninguno de los cuales se inicia por actividad exclusiva del organismo creado por la ley como agencia administrativa principal en materia medioambiental ${ }^{6}$.

\footnotetext{
${ }^{5}$ Para una distinción tentativa entre generaciones (modelos alternativos) de sistemas de regulación del medio ambiente, Stewart, Richard: "A New Generation of Environmental Regulation?”, 2001-2002, con indicación bibliográfica crítica y favorable al modelo de la primera generación en su nota 1 (pp. 22-23); con una visión más optimista de la capacidad de respuesta de la regulación medioambiental a los desafíos evolutivos, Esty, Daniel: "Next Generation Environmental Law: A Response to Richard Stewart" (20012002).

${ }^{6}$ Como es bien sabido, la aplicación de sanciones por infracción a los planes de manejo, prevención o descontaminación o a la regulación especial en situaciones de emergencia ambiental es de competencia del juez de letras en lo civil del lugar donde se genere el hecho, y el ejercicio de la acción respectiva corresponde a las municipalidades y
} 
Por supuesto, ninguna de estas explicaciones justifica la ausencia de un sistema sancionatorio eficaz, ya sea administrativo o específicamente punitivo. Como más adelante se verá, tampoco considero concluyentes los reparos usualmente formulados respecto de la legitimidad del uso de la pena como medio de reforzar la legislación medioambiental. Con todo, estimo que debe considerarse como una oportunidad valiosa para la deliberación política el hecho de que aún no exista entre nosotros derecho penal del medio ambiente. La experiencia comparada demuestra que tras un primer momento de intensa disposición política a la revisión reflexiva de las normas punitivas que se establecen, sobreviene una profunda inercia institucional. Si alguna función desempeña efectivamente el derecho penal medioambiental, ella no tiene lugar en el plano de los destinatarios de las normas de comportamiento que refuerza, sino de los agentes políticos competentes para revisar esas normas. El principal efecto cultural del derecho penal del medio ambiente es la consolidación irreflexiva del modelo de regulación administrativa al cual contingentemente se vincula ${ }^{7}$.

Ésta es una cuestión que el proyecto no se plantea. Ensimismado en su pretensión de ofrecer una regulación penal canónica, no alcanza a advertir que su propuesta asume acríticamente la corrección de la regulación administrativa vigente que refuerza mediante la pena. Una mirada a la re-

\footnotetext{
“demás organismos competentes del Estado” (Arts. 56, 58 y 60 Ley 19300). La aplicación de sanciones por incumplimiento de normas o condiciones sobre la base de las cuales se aprobó el estudio o se aceptó la declaración de impacto ambiental corresponde a la Comisión Nacional o Regional del Medio Ambiente, y el ejercicio de la acción respectiva corresponde a "los organismos del Estado que participen en el sistema de evaluación de impacto ambiental” (Art. 64, 65 Ley 19300). Las deficiencias del sistema de fiscalización son reconocidas en el informe de evaluación del período 1990-2004 efectuado por la Organización de Cooperación y Desarrollo Económicos y la Comisión Económica para América Latina y el Caribe: Evaluaciones del desempeño ambiental de la OCDE-Chile, 2005, p. 143 s., disponible en: http://www.direcon.cl/documentos/OCDE/ OCDE_EVALUACION_MEDIOAMBIENTAL.pdf).

${ }^{7}$ Para una (pesimista) visión de la situación del derecho medioambiental norteamericano, Lazarus, Richard L.: "Congressional Descent: The Demise of Deliberative Democracy in Environmental Law”, 2006. El caso alemán también es elocuente. El establecimiento de la $18^{\mathrm{a}}$ Ley de Reforma del Derecho Penal, de $1^{\circ}$ de julio de 1980 , que introdujo los delitos contra el medio ambiente en el Código Penal alemán, se explica entre otras razones como compensación de la incapacidad del Gobierno y el Parlamento alemanes para codificar la legislación ambiental —administrativa y penal— en un solo cuerpo sistemático de normas. Las disposiciones del Código Penal fueron reformadas por la $31^{\text {a }}$ Ley de Reforma del Derecho Penal, de 1 de noviembre de 1994; el proyecto de código del medio ambiente, en cambio, sigue sin realización (Steindorf, op. cit, supra, nota 3, p. 20). Para una crítica radical del derecho penal medioambiental alemán, basada en esta consideración, Jens Müller-Tuckfeld, Christian: "Ensayo para la abolición del Derecho Penal del medio ambiente", 2000, p. 507 s.
} 
flexión de los especialistas en derecho ambiental, sin embargo, parece demostrar lo contrario: independientemente de los éxitos logrados desde 1994 — que parecen concentrarse en la capacidad de absorción de proyectos por el sistema de evaluación de impacto ambiental—, si en algo coincide la mayoría de ellos es en el agotamiento y relativa inadecuación actual del modelo de coordinación y superposición ensayado por la Ley 19300, y en la necesidad de avanzar a un nuevo diseño institucional ${ }^{8}$. La pregunta de si ese nuevo diseño seguirá el modelo de la primera generación del derecho medioambiental o incorporará fórmulas de segunda o tercera generación, es una cuestión abierta. Mientras esas preguntas no encuentren respuesta satisfactoria en la legislación general sobre el medio ambiente, parece bastante obvio que no ha llegado aún la hora del derecho penal.

\section{El bien jurídico protegido y el modo de ataque relevante en el derecho penal del medio ambiente}

Parto de la base de que el establecimiento de una ley penal es un hecho institucional particularmente necesitado de legitimación ${ }^{9}$ debido a la inusual intensidad de su carácter potencialmente violador de derechos fun-

${ }^{8}$ Una muestra representativa se encuentra en las ponencias del seminario organizado por Expansiva sobre institucionalidad medioambiental el año 2006: Asenjo, Rafael: "Institucionalidad Pública y Gestión Ambiental en Chile”, 2006; Kausel, Teodoro: "Casos Emblemáticos para la Institucionalidad Ambiental Chilena”, 2006; Larraín, Sara: "Desafíos Ambientales del Desarrollo Nacional. Evaluación Desempeño 1997-2006 y Propuesta Institucional”, 2006; Vergara, Javier: "Criterios a Tener en Cuenta para la Discusión de una Política y una Institucionalidad Ambiental en Chile”, 2006; Lavín, Julio: "El SEIA: Visión Crítica a 10 Años de su Vigencia, Expansiva”, 2006; López, Ganni: "Propuesta de una Nueva Institucionalidad para la Fiscalización Ambiental de la Industria”, 2006; Figueroa, Eugenio, y Domique Hervé: "Evaluación del Marco Institucional y de la Gestión Ambiental en Chile”, 2006. Parcialmente en contra, sosteniendo que las deficiencias del sistema ambiental no obedecen a defectos de regulación, Dinamarca, Jaime: "Contaminación en Chile: ¿Fallas de la Institucionalidad o Problemas de Gestión?”, 2006. La crítica al diseño institucional de la Ley 19300 se encuentra también en propuestas recientes de reforma regulativa: Barton, Jonathan, Francisca Reyes, Priscilla Álamos, Sergio Galilea y Manuel J. Prieto, "El Nuevo Diseño de la Institucionalidad Ambiental en Chile”, 2007, pp. 137-178; FerradaNehme: "Informe sobre Institucionalidad Ambiental", 2007 (disponible en: http:// www.conama.cl/especiales/1305/articles40867_infoInstitucionalidadFN.pdf).

${ }^{9}$ Por "legitimación" entiendo la satisfacción de una exigencia de justificación racional que no es posible lograr exclusivamente en base a razones institucionales. Para la legislación de una democracia constitucional esta exigencia parece doblemente superflua. Por una parte esa legislación se encuentra prima facie legitimada atendiendo a su forma, por la congruencia que existe entre los procedimientos democráticos y la idea procedimental de justicia (es decir, las razones institucionales tienen un peso moral sustantivo), y por otra parte esa legislación puede ser siempre impugnada atendiendo a su contenido, 
damentales. Esto, por tres razones: (a) por su carácter de norma sancionatoria y de norma de comportamiento, (b) por el sentido condenatorio de su aplicación judicial, y (c) por las medidas coercitivas del proceso penal que indirectamente autoriza.

(a) La ejecución de una pena es una acción coercitiva (o una serie de múltiples acciones coercitivas) que afecta intereses humanos correlativos a derechos fundamentales, como la libertad ambulatoria, la vida privada, la intimidad, la propiedad o la libertad general de acción. Esa acción (o esa serie de acciones) se justifica institucionalmente por remisión a la parte dispositiva de una sentencia condenatoria. Esta segunda acción es un acto de habla que se justifica institucionalmente en la parte considerativa de la misma sentencia, como acto de aplicación de la ley penal. Si ambas justificaciones satisfacen sus presupuestos institucionales específicos, en la legitimidad de la ley penal se encuentra una condición de la legitimación de acciones que de otro modo serían intolerables en un orden político comprometido con la vigencia de los derechos fundamentales. Conforme a su sentido proposicional la ley penal sólo ordena la imposición y ejecución de una pena (por lo que, en conjunción con reglas de adjudicación, autoriza para hacerlo). No obstante, por diversas razones tanto los individuos que se pueden ver afectados con su aplicación como los funcionarios estatales encargados de esa aplicación reconstruyen el sentido de la ley penal, y la comprenden también como una norma de comportamiento que prohíbe o

bajo la prohibición de arbitrariedad que se deriva del principio de igualdad ante la ley (es decir, las razones institucionales no inmunizan a la legislación de este examen de legitimidad). La necesidad de legitimación a que aludo se despliega sobre este horizonte de referencia: ambas consideraciones resultan insuficientes cuando la legislación afecta deliberadamente un interés humano correlativo a un derecho fundamental. Dependiendo de la teoría de los derechos fundamentales que se postule como interpretación correcta del orden constitucional, la tesis puede entenderse bajo una distinción binaria (hay o no hay necesidad adicional de legitimación) o de tránsito fluido entre sus casos paradigmáticos opuestos (hay siempre mayor o menor necesidad adicional de legitimación). Si se postula la calidad de derecho fundamental de la libertad general de acción y se admite la distinción entre posición prima facie protegida y posición definitivamente protegida por un derecho fundamental, entonces toda ley - y no sólo las leyes penales— está sujeta a legitimación adicional en el sentido indicado, en mayor o menor medida. Si se opta por las tesis básicas opuestas, entonces son las leyes que imponen penas privativas de libertad, y particularmente, las que las imponen en un grado no susceptible de sustitución por una medida restrictiva de libertad, las que constituyen el caso necesitado de legitimación. Para la idea de la legitimación procedimental del Estado de derecho, Habermas, Jürgen: “Acerca de la Lógica de los Problemas de Legitimación” (1975) 1986, p. 117; el mismo: “¿Cómo es Posible la Legitimidad por Vía de Legalidad?”, 1991, p. 131. Para la distinción entre una y otra concepción de los derechos fundamentales, Borowsky, Martin: "La Restricción de los Derechos Fundamentales”, 2000, p. 29 s. 
manda la acción cuya realización u omisión acarrea como consecuencia debida la pena. En tanto norma de comportamiento, la ley penal necesita además legitimación por la restricción de libertad que necesariamente conlleva su observancia, o por la restricción del ejercicio o goce de otro derecho fundamental que eventualmente conlleve su observancia (dependiendo del contenido de la ley, por ejemplo: la vida privada, la libertad de expresión, de trabajo o de actividad económica) ${ }^{10}$.

(b) La imposición judicial de la pena establecida en la ley penal es la consecuencia institucional de la condena del acusado por el tribunal. La condena admite ser entendida como un acto de habla institucionalmente diferenciado que tiene el sentido de un reproche público por la infracción de una norma. Ese reproche afecta diversos intereses humanos, por lo general comprendidos en el "derecho a la personalidad": la vida privada, la intimidad, la propia imagen, el honor en el sentido de la consideración social ${ }^{11}$.

${ }^{10}$ Desde un punto de vista estrictamente utilitarista, la ley penal debe ser reconstruida no como norma de comportamiento sino como coacción mediante amenaza. Esto tiene como ventaja que hace evidente en un nivel fáctico de referencia el modo como la ley penal afecta la libertad general de acción (o el eventual ejercicio o goce de otro derecho), y que respeta en el plano teórico y práctico la posición del disidente moral. Tiene sin embargo la desventaja de hacer invisibles las diversas manifestaciones de la dimensión de sentido de la acciones de seguir e infringir una regla. Además, impide advertir la doble distribución de autonomía implicada en una ley penal. Toda norma de comportamiento introduce una primera distribución de libertad, suprimiendo la libertad respecto de algunas acciones a favor (indirectamente) de la libre realización de otras acciones. Toda norma punitiva introduce una segunda distribución de libertad, ordenando suprimir (directa o indirectamente) un margen de libertad del infractor de la norma de comportamiento. Por diversas razones es correcto considerar a la finalidad de la norma de comportamiento como finalidad propia de la norma punitiva (sobre esto se volverá más adelante, en la nota 23). No obstante, por diversas razones también es conveniente efectuar la distinción. Por ahora, basta con observar que no hay simetría entre la afirmación y la negación de la legitimidad de la norma punitiva por inferencia a partir de la evaluación de la norma de comportamiento: de la ilegitimidad de una norma de comportamiento se deduce la ilegitimidad de la norma punitiva correlativa, pero de la legitimidad de una norma de comportamiento no se deduce la legitimidad de la norma punitiva correlativa.

${ }^{11}$ La idea de que el reproche por la infracción de la norma es el sentido constitutivo de la condena es característica de la justificación retribucionista de la práctica punitiva (al respecto, Mañalich, Juan Pablo: “La Pena como Retribución”, 2007, p. 117 s.). No es necesario, sin embargo, compartir ese punto de vista para reconocer la específica potencialidad lesiva del derecho general de la personalidad que reviste la condena. Basta con la constatación de que en el contexto social la condena produce ese efecto, lo que es enteramente compatible con una justificación utilitarista de la pena, para que sea relevante esa dimensión de sentido en su caracterización como acto estatal de afectación de derechos fundamentales. Dicho en los términos de la teoría de los de habla, en su versión por Jürgen Habermas, para admitir que la condena es una fuente específica de peligro para los derechos fundamentales no se necesita sostener que en su sentido ilocucionario ella constituye un reproche; basta con advertir que los efectos lesivos de los diversos aspectos del derecho de la personalidad corresponden lo que usualmente es su sentido perlocucionario. 
(c) La ley penal se encuentra institucionalmente relacionada con la justificación de diversos actos intrusivos o coercitivos propios del proceso penal, como algunas medidas de investigación y las así denominadas "medidas cautelares", especialmente las personales. A diferencia de los actos estatales anteriores, estas medidas no se justifican institucionalmente como actos de aplicación de la ley penal. No obstante, la existencia de una ley penal cuyo contenido proposicional sea semánticamente correlacionable con las aserciones constatativas que el ministerio público debe efectuar en un juicio para sustentar la acción penal es un presupuesto de la investigación y del juicio, y por lo mismo de las medidas coercitivas que eventualmente sean adoptadas en el contexto de aquélla y éste.

En términos generales, se puede decir que conforme al discurso europeo-continental referido a cuestiones legitimatorias de las normas punitivas la ley penal debe satisfacer tres conjuntos de condiciones específicas de legitimación, es decir, condiciones adicionales a los requisitos de carácter institucional que debe satisfacer toda ley ${ }^{12}$. En primer lugar está el grupo de condiciones procedimentales específicas que el discurso europeo-continental reúne bajo el principio de legalidad. En segundo lugar se encuentra el grupo de condiciones que debe satisfacer toda atribución de responsabilidad (penal) por la infracción de una norma de comportamiento, y que el discurso europeo-continental reúne bajo el principio de culpabilidad. Finalmente, está el conjunto de condiciones de racionalidad teleológica y (eventualmente) exigencias derivadas de las condiciones de atribución que el discurso europeo-continental reúne bajo el principio de protección exclusiva y subsidiaria de bienes jurídicos. El nivel de claridad de las consecuencias derivadas de estos principios es progresivamente decreciente.

${ }^{12}$ Me refiero aquí específicamente al discurso de la profesión jurídica universitaria. En su calidad de heredero de la Ilustración, ese discurso acerca de la legitimación de la norma punitiva ha tenido tradicionalmente un estatus ambiguo. Pretende ser un discurso vinculante, pero se desentiende de las condiciones institucionales de esa vinculación al autocomprenderse como reflexión político-criminal. Es perceptible sin embargo en la doctrina alemana reciente una tendencia a la redefinición de ese discurso con el objetivo de hacerlo operativo como estándar de evaluación de la constitucionalidad de la ley penal. Así, en las obras de Lagodny, Otto: Das Strafrecht vor den Schranken der Grundrechte (El derecho penal ante los límites de los derechos fundamentales), 1996; Appel, Ivo: Verfassung und Strafe (Constitución y pena), 1998, y Stächelin, Gregor: Strafgesetzgebung im Verfassungsstaat (Legislación penal en el Estado constitucional), 1998. Esa es la tendencia con la que se identifican estas reflexiones. La asunción de esta dimensión institucional conlleva una disminución de las pretensiones de rendimiento del discurso en cuestión. Una teoría constitucional de la legitimación de la ley penal tiene que distinguir entre el —estrecho - ámbito de las razones morales institucionalmente reconocibles como indisponibles para el legislador y el —extenso — ámbito plural de las razones que compiten por lograr la adhesión de la mayoría. La pretensión vinculante del discurso de la política criminal pertenece a este segundo ámbito, tal como el discurso práctico general. 
Tratándose del principio de protección exclusiva y subsidiaria de bienes jurídicos, puede decirse que persigue los siguientes objetivos: (i) cumple una primera función evaluativa de la finalidad de protección de la norma de comportamiento, análoga al test de legitimidad del fin abstractamente considerado que es propio del examen general de constitucionalidad de una actuación estatal; (ii) cumple una segunda función evaluativa de la finalidad de protección de la norma de comportamiento, mediante una función heurística en la determinación precisa de esa finalidad, vinculando su justificación a una descripción del estado de cosas valioso cuya alteración se considera legítimamente suprimible del ámbito de libertad de los individuos; (iii) cumple las funciones evaluativas, tanto de la norma de comportamiento como de la norma punitiva, que corresponden a los tests de adecuación y proporcionalidad lato sensu (necesidad), que son propios del principio de proporcionalidad en su aplicación como criterio prospectivo de racionalidad; (iv) cumple la función evaluativa de la norma punitiva otorgada por el test de proporcionalidad stricto sensu, no sólo en términos prospectivos, es decir, comparando la magnitud de la pena con la relevancia del fin perseguido por el legislador, sino en una redefinición de ese test bajo un criterio retrospectivo de racionalidad, conforme al cual la magnitud de la pena no ha de rebasar la gravedad del delito cometido, entendida esa gravedad como el resultado de la ponderación de pocas variables: el valor comparativo del estado de cosas afectado, la magnitud de su afectación y la intensidad de la culpa del responsable ${ }^{13}$.

${ }^{13}$ Esta exigencia retrospectiva de proporcionalidad concuerda evidentemente con la prohibición de exceso derivable de una justificación retribucionista de la pena. En el discurso moderno sobre legitimación de las leyes penales es usual sin embargo su formulación bajo una consideración prospectiva: la severidad de la pena debe corresponder a la gravedad del delito cuya comisión se pretende evitar (así, Montesquieu: Del Espíritu de las Leyes, 1972, libro vi, capítulo xvi, p. 110). Lo crucial de la redefinición del test de proporcionalidad stricto sensu por el discurso acerca de la legitimación de la ley penal es el carácter selectivo de las variables tomadas en consideración para la determinación de la magnitud proporcional de la pena. El hecho que la pena sea determinada ex ante por el legislador no altera el carácter retrospectivo de su determinación, es decir, que las variables tomadas en consideración por el legislador correspondan exclusivamente a propiedades del hecho punible cuya constatación posterior por el juez exige referencia al momento de la comisión del delito. Por otra parte, es importante señalar que esta exigencia de proporcionalidad retrospectiva usualmente se considera una consecuencia del principio de culpabilidad, que ya no está referida al "sí-o-no" de la pena (punibilidad, que es el aspecto considerado arriba en el texto), sino al "qué" y "cuánto" de la misma (determinación legal y judicial de la pena). No obstante la corrección de este punto de vista sistemático, en la medida en que las variables exclusivas de determinación de ese "qué" y "cuánto" estén dadas por el valor comparativo del estado de cosas afectado y la intensidad comparativa de su afectación, el principio de proporcionalidad retrospectiva es sistemáticamente un componente del principio de exclusiva protección de bienes jurídicos, por lo menos en lo que respecta al umbral de la determinación legal de la pena. 
En sus funciones (i) y (iii) el principio de exclusiva protección de bienes jurídicos nada añade a las condiciones generales de evaluación de la legitimidad de la legislación bajo los estándares constitucionales. Es en sus funciones (ii) y (iv) donde se concentra su pretendida especificidad como conjunto de condiciones de legitimación de las normas punitivas (y sus correlativas normas de comportamiento). En forma resumida, estas dos funciones del principio de exclusiva protección de bienes jurídicos exigen que el comportamiento descrito como delito — es decir, la infracción de la norma de comportamiento - sea susceptible de caracterización como una afectación de tanta entidad de un estado de cosas tan valioso que se justifique la supresión de un margen de libertad tan considerable como el que conlleva la pena ${ }^{14}$. La naturaleza precisa de este canje elemental es objeto de controversia. Desde un punto de vista moderadamente utilitarista, estas exigencias de referencia descriptiva y proporcionalidad son medios racionalmente adecuados y necesarios para configurar en general un sistema de control del comportamiento que pueda obtener como resultado la evitación de la comi-

${ }^{14}$ El principio de la exclusiva protección de bienes jurídicos tiene su equivalente en la cultura anglonorteamericana en el principio del daño (harm principle), formulado por John S. Mill en el siglo xix y desarrollado exhaustivamente por Joel Feinberg en la segunda mitad del siglo xx (infra, nota 17). La apreciación del rol que puede jugar el harm principle como criterio de legitimación de la ley penal requerido por la Constitución, conforme a la jurisprudencia de la Corte Suprema Federal de los Estados Unidos de Norteamérica, requiere una distinción. En cuanto a su pretendida función (ii) señalada en el texto, ella debe desplegarse en el marco de la distinción entre afectación de un interés general de libertad y afectación de un derecho constitucional nominativo y en el particular contexto del derecho al debido proceso sustantivo, propios de la jurisprudencia desarrollada por la Corte. En cuanto a su pretendida función (iv), la Corte sostiene que, fuera de los casos de pena de muerte, la Constitución no requiere una proporcionalidad estricta ("strict proportionality" en la terminología acuñada por la opinión concurrente en Harmelin v. Michigan, 501 U.S. 957 [1991]), sino que sólo exige satisfacer un estándar de proporcionalidad reducida ("narrow proportionality", en la misma terminología). Esto significa, en primer lugar, que sólo las penas burdamente desproporcionadas ("grossly disproportionate") resultan inconstitucionales, lo cual representa un principio de deferencia hacia una prerrogativa de decisión del legislador. En segundo lugar, y lo que es más importante, la tesis implica que las variables para apreciar la justificación de la magnitud de la pena no se reducen a las propiedades del hecho cometido; es decir, implica la afirmación de un criterio de proporcionalidad prospectiva, con explícito rechazo de un criterio exclusivamente retrospectivo de proporcionalidad. Con esta tesis la Corte ha afirmado la constitucionalidad de la imposición de presidio perpetuo sin libertad bajo palabra por portar 650 gramos de cocaína (Harmelin, cit.), de presidio perpetuo sin libertad bajo palabra durante 25 años por hurtar, en reincidencia, tres palos de golf (Ewing v. California 538 U.S. 11 [2003]) o cinco videos (Lockyer v. Andrade 538 U.S. 63 [2003]). Una visión de conjunto sobre el posible sentido de un test de proporcionalidad puede verse en Frase, Richard S.: "Excessive Prison Sentences, Punishment Goals and the Eighth Amendment: Proportionality Relative to What?”, 2005. 
sión de delitos. Desde un punto de vista retribucionista, son presupuestos de la aceptabilidad racional de la imposición de una pena como acto de reproche por la infracción de la norma. En la primera perspectiva, la consideración del delito como afectación de un bien jurídico justifica directamente la norma punitiva, entendida como acción estratégicamente orientada a su evitación; en la segunda, esa consideración justifica la relevancia de la norma de comportamiento, que a su vez justifica la norma punitiva, entendida como acción comunicativamente orientada a la afirmación de la vigencia de una norma ${ }^{15}$.

En este contexto evaluativo, el establecimiento en la segunda mitad del siglo xx de normas punitivas que sancionan atentados contra el medio ambiente ha generado discusión principalmente acerca de tres aspectos que aparecen como problemáticos: (i) la definición de la perspectiva desde la cual ha de decidirse el valor de la conservación del medio ambiente, (ii) la determinación de la medida de relevancia de su afectación, y (iii) la determinación en términos de daño potencial (eventual o futuro) de lo que ha de contar como afectación actual (presente) del medio ambiente.

(i) La primera dificultad es usualmente planteada en términos de si el merecimiento de protección del medio ambiente ha de justificarse desde una perspectiva ecocéntrica, es decir, estimando que la protección de la naturaleza se debe por consideración a ella misma, o antropocéntrica, es decir, reconduciendo la justificación de su protección a un interés humano. En la postura dominante ese planteamiento disyuntivo es inmediatamente sustituido por el desarrollo de una tesis mediadora, conforme a la cual lo correcto ha de encontrarse en la vía media de un antropocentrismo (o ecocentrismo) moderado. Con ello, por supuesto, no se ha resuelto sino apenas planteado el problema. En un estado secular de derecho se encuentra excluida la apelación a la sacralidad de la naturaleza. El merecimiento de protección del medio ambiente ha de justificarse, por lo tanto, como un interés de las personas en la preservación o mejora de su estado. Eso no significa que el medio ambiente sólo pueda ser considerado como valioso en la medida en que sea presupuesto fáctico de otros intereses cuyo merecimiento de protección sea indiscutido, como la vida y la salud de los individuos. Por supuesto que la

${ }^{15}$ La misma alternativa que se abría a la consideración del potencial lesivo de la condena para el derecho a la personalidad (supra, nota 11) se abre para la consideración de la relación entre condena y afirmación de la norma de comportamiento infringida: esa afirmación puede ser entendida como constitutiva del sentido de la condena (dimensión ilocucionaria) o como efecto producido por la condena (dimensión ilocucionaria). La primera perspectiva es la del retribucionismo; la segunda corresponde a la variante utilitarista denominada en la doctrina alemana y española como "prevención general positiva”. 
conservación del medio ambiente es condición de subsistencia de las especies vivas, dentro de ellas la humana, y no sólo para un futuro remoto, como también un presupuesto de la salud de la población. Pero de eso no se sigue que sea sólo esa dimensión del medio ambiente la que pueda corresponder a un interés legítimo. Una postura que restrinja así el merecimiento de protección del medio ambiente sencillamente lo desconoce como objeto de protección ${ }^{16}$. El problema se encuentra en precisar qué otros intereses en la conservación del medio ambiente pueden cumplir con las condiciones que hacen legítimo su favorecimiento con cargo a una restricción de la libertad general de acción (más la eventual restricción del ejercicio de alguna libertad constitucional específica) e imponiendo una pena en caso de infringirse esa restricción.

En términos del desarrollo hecho por Joel Feinberg del principio del daño (harm principle), el estado de cosas que es objeto de daño, en el sentido del principio, debe corresponder a aquello que en el contexto de la red de intereses de los seres humanos Feinberg denomina como un "interés de bienestar" (welfare interest), es decir, un deseo estable y permanente en la disposición sobre condiciones que representan medios generalmente necesarios para la realización de una amplia variedad de fines ulteriores (polivalencia) y que mantienen entre sí una relación tal que la mayor posesión de alguno(s) de ellos no compensa la deprivación de otro (no-compensatoriedad $)^{17}$. Dentro de esta categoría también se encuentran los intereses públicos, que Feinberg clasifica —en este contexto— en dos clases, según si

${ }^{16}$ Ejemplar en este respecto es el Proyecto Alternativo alemán: “Bajo la expresión "protección del medio ambiente" son crecientemente mencionados en la opinión pública [los peligros para la vida y la salud humana que surgen ante todo de los procesos productivos que ponen en peligro el medio ambiente y de los productos masivos dañinos para la salud]. Con todo, su caracterización como "protección del medio ambiente” es apta para minimizar o encubrir los problemas aquí involucrados: no se trata de la protección del medio ambiente, sino solamente de la protección de la vida humana y la salud humana ante los peligros del medio ambiente" (Alternativ-Entwurf eines Strafgesetzbuches, Besonderer Teil, Straftaten gegen die Person, Zweiter Halbband [Proyecto alternativo de un código penal, Parte especial, Hechos punibles contra la persona, Tomo segundo], 1971, p. 49, el destacado es del original). Consecuentemente, el Proyecto Alternativo cierra el apartado relativo a los "Delitos contra las personas", con los títulos ix y x, dedicados a las "Puestas en peligro de personas” (§§ 151-162) y a las "Puestas en peligro en el tráfico” (§§ 163-169).

${ }^{17}$ Feinberg, Joel: Harm to Others, 1987, pp. 37-38 y 55-61. Para una apreciación de la obra de Feinberg desde la perspectiva europeo-continental, Seher, Gerhard: Liberalismus und Strafe. Zur Strafreechtsphilosophie von Joel Feinberg (Liberalismo y pena. Acerca de la filosofía del derecho penal de Joel Feinberg), 2000. Para una crítica de la capacidad de rendimiento del harm principle como estándar sustantivo de control de legitimidad de la legislación penal, Dripps, Donald A.: "The Liberal Critique of the Harm Principle”, 1998. 
son primariamente compartidos por los individuos en su uso instrumental o bien si son primariamente instrumentales a la realización de las funciones de las instituciones estatales. La disposición sobre un "medio ambiente tolerable” es, según Feinberg, un interés de bienestar público en el primer sentido mencionado. Esto, con total independencia de la afectación de la vida o la salud de personas determinadas o indeterminadas como resultado o riesgo de la alteración del medio ambiente.

En términos de Roland Hefendehl, una figura central en la rehabilitación alemana del concepto de bien jurídico como premisa de una concepción que afirma la irreductibilidad de los bienes colectivos, los recursos del medio ambiente constituyen una subclase de aquellos bienes colectivos cuya protección garantiza espacios de libertad para los individuos —bienes de la sociedad civil—, y que se caracteriza por acompañar permanentemente la vida (en el sentido de la actividad biográfica) de los miembros de la sociedad. Específicamente, los recursos naturales son contingentes socialmente relevantes consistentes en hechos brutos y consumibles: ambas propiedades los distinguen de los bienes colectivos institucionales que proveen confianza, como la fe pública ${ }^{18}$.

Como salta a la vista, ambas perspectivas coinciden en identificar ciertos medios naturales — por ejemplo, agua, luz, suelo- de uso o consumo colectivo, respecto de los cuales todos tenemos interés en conservarlos en un determinado estado de calidad de uso. La acción caracterizable como un atentado relevante contra ese estado constituiría un acto merecedor de prohibición penalmente reforzada, con independencia de si ese atentado causa o puede causar la muerte, la enfermedad o el malestar corporal de algún individuo. En el plano de la legislación penal comparada, la opción legislativa por la protección del medio ambiente como un bien jurídico colectivo irreductible a la lesión o puesta en peligro de la vida o la salud individuales, se define del mismo modo. Es decir, si la descripción legal de la acción que incide sobre el medio ambiente no incluye dentro de las propiedades de esa acción la puesta en peligro de la vida o la salud de una o más personas, determinadas o indeterminadas, entonces se entiende que el legislador protege el medio ambiente así concebido.

Semejante resultado es, por cierto, insuficiente. La identificación del bien jurídico no está lograda con la sola determinación del estado de cosas considerado como valioso, ni de su propiedad específicamente valiosa, sino con la determinación de ambas más las razones justificatorias de esa atribu-

${ }^{18}$ Hefendehl, Roland: Kollective Rechtsgüter im Strafrecht (Bienes jurídicos colectivos en el derecho penal), 2002, especialmente pp. 132-134, 306-312. 
ción de valor. En este sentido, la concepción de Feinberg parece apuntar más a la calidad de vida de los afectados por la alteración del medio ambiente, mientras que la concepción de Hefendehl pareciera orientarse al aseguramiento sostenido del uso de los recursos naturales, incluyendo su uso por generaciones futuras. Ambas son consideraciones pertinentes en el contexto de la Ley 19300, que reconoce como intereses humanos legítimos relacionados con la protección del medio ambiente no sólo la exclusión del riesgo para la salud de la población, sino la calidad de vida de ésta, el uso y aprovechamiento de los recursos naturales y la preservación en particular de componentes del medio ambiente que sean únicos, escasos o representativos $^{19}$. A estas consideraciones puede sumarse la identificación de los intereses en la conservación del medio ambiente que se expresan en los instrumentos internacionales vinculantes para el Estado de Chile ${ }^{20}$.

Un ejercicio de esta índole demuestra que es posible articular en términos conceptuales una definición de los intereses humanos en la conservación y mejora del estado de los elementos componentes de medio ambiente y sus relaciones, por encima de su potencial efecto lesivo para la vida y la salud de las personas. Aún no demuestra, sin embargo, que esos intereses posean todas las propiedades características de los intereses de bienestar, en el sentido de Feinberg. En casos de exigencias radicales de conservación, su polivalencia será discutible; en casi todos los casos, lo que aparece como discutible es su posición no compensable en la red de intereses de bienestar de las personas.

La existencia de un imperativo constitucional o internacional de protección penal de tales intereses cumple obviamente la función de compensar ese déficit de peso específico comparativo. Por eso no es de extrañar que el discurso alemán o español favorable a la incriminación de atentados a esos intereses termine inevitablemente haciendo referencia a una norma

${ }^{19}$ Así resulta de las definiciones de "contaminante" (Art. $2^{\circ}$-d) y "daño ambiental” (Art. $2^{\circ}$-e), correlacionadas con las definiciones de "biodiversidad”, "conservación del patrimonio ambiental", "desarrollo sustentable", "medio ambiente" y "medio ambiente libre de contaminación” (Art. $2^{\circ}$, literales a, d, g, ll y m). La distinción entre el interés en excluir el riesgo para la vida y la salud de la población y los demás intereses relativos a la conservación del medio ambiente es la base sobre la cual la ley establece distinción institucional entre las normas primarias de calidad ambiental y las normas secundarias de calidad ambiental (Arts. $2^{\circ}$-n y -ñ, 32 Ley 19300, Arts. 2 ${ }^{\circ}$, 3, 24-32 Reglamento para la dictación de normas de calidad ambiental y de emisión, Decreto Supremo No 93, D.O. de 26 de octubre de 1995). Esta distinción proviene del derecho medioambiental norteamericano (por ejemplo, 42 U.S.C. § 7409-(b), relativo a la calidad del aire).

${ }^{20}$ Para un listado de instrumentos internacionales relevantes en este sentido, Matus, Orellana, Castillo, Ramírez: “Análisis dogmático...”, op. cit. supra, nota 2, pp. 18-22. 
constitucional interpretable en ese sentido ${ }^{21}$. Ese modo de cancelar la cuestión no satisface, sin embargo, la necesidad de legitimación. Desde luego, un imperativo supralegal inequívoco de protección penal ha de aceptarse como razón justificatoria de la decisión legislativa. Pero la interpretación de imperativos generales de protección o de imperativos de sanción como imperativos de protección penal es simplemente un error $^{22}$.

${ }^{21} \mathrm{El}$ art. 20-a de la Ley Fundamental de la República Federal Alemana dispone "El Estado protege, también como responsabilidad para con las futuras generaciones, las bases naturales de la vida y los animales, en el marco del orden conforme a la constitución mediante la legislación, y conforme a la ley y al derecho mediante los poderes ejecutivo y judicial”. Por su parte, el Art. 45 de la Constitución española de 1978 dispone “1. Todos tienen el derecho a disfrutar de un medio ambiente adecuado para el desarrollo de la persona, así como el deber de conservarlo. 2. Los poderes públicos velarán por la utilización racional de todos los recursos naturales, con el fin de proteger y mejorar la calidad de la vida y defender y restaurar el medio ambiente, apoyándose en la indispensable solidaridad colectiva. 3. Para quienes violen lo dispuesto en el apartado anterior, en los términos que la Ley fije se establecerán sanciones penales o, en su caso, administrativas, así como la obligación de reparar el daño causado".

${ }^{22}$ El tratamiento de las normas de derecho constitucional y de derecho internacional como imperativos para el legislador estatal exige distinguir entre imperativos de protección, imperativos de protección normativa, imperativos de protección normativo-sancionatoria (imperativos de sanción), imperativos de protección normativo-punitiva (imperativos de punición), e imperativos de tipificación, en un sentido tal que cada imperativo posterior en ese orden presupone los imperativos que lo anteceden (al respecto, Bascuñán, Antonio: "Derechos Fundamentales y Derecho Penal. Seminario en Latinoamérica de Teoría Constitucional y Política (SELA) 2001”, 2002, p. 319 s. (especialmente pp. 329-333); también en Revista de Estudios de la Justicia No 9 (2007), p. 47 s (especialmente pp. 59-64). Una preferencia hermenéutica por la mayor intensidad posible del imperativo desconoce que la eficacia del propósito de protección no es el único interés en juego: también es crucial la preservación de una prerrogativa de decisión del legislador democrático que sea funcional a la satisfacción de la necesidad creciente de legitimación de las decisiones estatales implicadas por esos imperativos. De ahí que el principio hermenéutico correcto sea que en caso de incertidumbre debe prevalecer la interpretación más favorable a la prerrogativa de decisión del legislador, a menos que ello haga ineficaz el propósito de protección del imperativo. Así, un imperativo de sanción no implica un imperativo de punición, si un esquema de sanción administrativa es funcionalmente adecuado a la realización del fin de protección del imperativo. La ausencia de un esquema suficientemente diferenciado de interpretación del sentido de los instrumentos internacionales y la idea, completamente equivocada, de que un instrumento que no imponga deberes de punición constituye soft law, conduce a Matus y Castillo a atribuir el carácter de imperativos de punición a deberes internacionales que en sus propios términos constituyen imperativos de sanción, como los establecidos en el tratado antártico sobre protección de medio ambiente (1991), la convención sobre el comercio internacional de especies amenazadas de fauna y flora silvestres (1973), el convenio internacional para prevenir la contaminación por los buques (1973/ 1978), el convenio sobre prevención de la contaminación del mar por vertimientos de desechos y otras materias (1972), la convención sobre la prohibición del desarrollo, la producción y el almacenamiento de armas bacteriológicas y tóxicas (1972) y el tratado que prohíbe las pruebas de armas nucleares en la atmósfera, el espacio exterior y el mar (1963) (Matus (ed.): Derecho Penal, op. cit., supra, nota 2, pp. 38-44). 
Preferible me parece una honesta asunción del carácter controvertido del peso específico comparativo (no-compensatoriedad) de los intereses en la protección del medio ambiente que excedan al interés en la exclusión de riesgos para la vida o la salud. Esto no significa que se haya negado esa propiedad: simplemente que de modo inmediato no se la puede afirmar tan concluyentemente como tratándose de otros intereses de bienestar. Fuera de discusión está, por el contrario, su carácter de fines estatales legítimos en sí mismos considerados, $\mathrm{y}$, al menos en lo que respecta al interés en la calidad de vida y en el aseguramiento de la disponibilidad de recursos para el futuro, su carácter de intereses polivalentes. Este resultado provisorio satisface la asunción del principio de exclusiva protección de bienes jurídicos como un estándar de exigencia moderada, y deja a cargo del sentido legitimatorio de la satisfacción de los procedimientos democráticos la compensación del posible déficit de justificación sustantiva de la protección penal del medio ambiente por encima de la puesta en peligro de la vida y la salud de las personas ${ }^{23}$.

${ }^{23}$ Tampoco me parece razonable negar la relevancia del principio de exclusiva protección de bienes jurídicos atendida la función primariamente comunicativa (es decir, no instrumental) de la protección penal. Conforme a esta idea, la legitimación de la norma punitiva debería atender a la relevancia de la norma de comportamiento para la identidad normativa de la sociedad. Desde luego, esto implica una alteración de los términos con que es formulada la tesis en el contexto del funcionalismo jurídico-penal, y que son puramente constatativos: el recurso a la pena como reacción a la infracción demuestra que la norma infringida es considerada como constitutiva de la identidad normativa de la sociedad (así, Jakobs, Günther: "Das Strafrecht zwischen Funktionalismus und alteuropäischem Prinzipiendenken" [El derecho penal entre el funcionalismo y el pensamiento de principios tradicional europeo], 1995, p. 843). Asumir la tesis en sentido evaluativo implica atribuir a la afirmación contenida en la ley penal una pretensión de validez susceptible de desempeño argumentativo, mientras que el uso meramente descriptivo de esa categoría no requiere tal asunción. No hay problema, por supuesto, en hacer discursivamente responsable al legislador por sus afirmaciones, es decir, en atender a la "referencia inmanente a la verdad" de esa convicción fácticamente constatable en la legitimidad de la norma (en el sentido de Habermas: “Acerca de la Lógica...”, op. cit. nota 9, p. 119). Pero eso sólo puede tener un potencial crítico si se dispone de una matriz conceptual que permita el control argumentativo de la racionalidad de esa afirmación. ¿Qué puede contar, sin embargo, como criterio de atribución o denegación de la relevancia de una norma para la constitución de la identidad normativa de una sociedad en sustitución de las exigencias de una justa distribución de autonomía en los dos niveles que son propios de la legitimación material de las normas penales conforme a la teoría del bien jurídico? La exigencia de legitimación racional de la norma de comportamiento en tanto norma penalmente reforzada, es decir, en tanto correlato de una norma punitiva, tiene un potencial crítico que se diluye si se justifica la norma de comportamiento como sola afectación de la libertad general de acción, y luego se justifica la norma punitiva atendiendo a criterios independientes de la primera justificación. Esa desvinculación oculta el carácter específicamente coercitivo de una norma sancionatoria y la peculiar intensidad coercitiva de una norma punitiva. 
(ii) Es un lugar común, fácilmente comprensible por lo demás, advertir que el medio ambiente no puede ser concebido como un estado de cosas que sea razonable pretender mantener inalterado. La protección del medio ambiente sólo puede consistir en la evitación de una determinada medida o clase de alteración del mismo. Queda por discernir qué consecuencias se derivan para el derecho penal de semejante proposición.

Desde luego, la diferencia no se encuentra en el carácter “dinámico” o "relativo" del medio ambiente por oposición a un carácter "estático” o “absoluto” de los bienes jurídicos tradicionales. Todos los bienes jurídicos son susceptibles de ser caracterizados como presupuestos del libre desarrollo de la personalidad, incluyendo la participación del individuo en la interacción socialmente significativa, y en esa medida, dinámicos; en términos de Feinberg, son intereses instrumentales y no intereses ulteriores. Por otra parte, tratándose de la gran mayoría de los bienes jurídicos la distribución de autonomía que efectúa la norma de comportamiento es reversible (derrotable). Esto quiere decir que, atendiendo a la peculiaridad de la situación, la norma puede resultar inaplicable al caso y el comportamiento respectivo debe ser calificado como permitido en vez de prohibido o mandado. Este es el efecto de las normas sobre causas de justificación, que efectúan otra distribución de autonomía, de aplicación preferente al caso, autorizando la afectación del bien jurídico en situaciones de conflicto de intereses, para favorecer un interés preponderante. En este sentido, toda protección penal de un bien jurídico susceptible de afectación justificada puede caracterizarse como relativa.

Lo que caracteriza al medio ambiente como bien jurídico, por lo menos a la mayor parte de sus concreciones como objeto merecedor de protección, es que una determinada medida de afectación ha de encontrarse necesariamente permitida por las mismas razones que se justifica la prohibición de la afectación por encima de esa medida. Eso es obvio, tratándose del uso actual de recursos naturales renovables y su preservación para garantizar su disfrute futuro. Lo es también, tratándose de la contaminación: tanto la conservación de la vida y la salud, como el disfrute cierta calidad de vida requieren el despliegue de actividad humana que afecta la composición del medio ambiente. En este sentido, la protección penal del medio ambiente guarda una similitud con la protección penal de la libertad personal, entendida como libertad general de acción: la libertad que cabe considerar como objeto de protección es el resultado de un balance entre las razones que legitiman su restricción y las razones para preservar un ámbito irrestricto. Lo central para el derecho penal, tanto en la protección de la libertad como del medio ambiente, es que ese balance no admite expresión en un número 
reducido de normas de comportamiento, susceptibles de ser fijadas mediante el establecimiento de normas punitivas. Por el contrario, las normas punitivas que sancionan los atentados contra el medio ambiente o la libertad - luego, las normas de comportamiento correlativas - descansan en una determinación normativa previa del margen en que cabe reconocer en el objeto de ataque un objeto merecedor de protección. Esta es una de las razones que hacen a la protección penal del medio ambiente necesariamente dependiente de la regulación extra-penal, en el sentido examinado en la sección que sigue.

La relatividad del medio ambiente como objeto de protección también genera peculiaridades en la regulación medioambiental, que constituyen rasgos relevantes desde el punto de vista de la legitimación de las normas punitivas destinadas a reforzar su vigencia. Uno de estos rasgos es la reflexividad de la regulación medioambiental; el otro, su carácter aspiracional.

El derecho moderno es esencialmente reflexivo, en el sentido de que tematiza su propia producción y aplicación; en este sentido, toda regulación jurídica puede ser caracterizada como reflexiva. En este mismo sentido, se puede afirmar de la regulación medioambiental una peculiar intensificación de esa disposición institucional al cambio ${ }^{24}$. Pero lo que hace peculiar la reflexividad de la regulación medioambiental es su dependencia respecto de la información disponible acerca de los efectos medioambientales de la actividad humana y los medios técnicos de control. El reconocimiento de esa dependencia y la asunción de la controvertibilidad de la información disponible hace que el aseguramiento institucional del flujo de información verosímil asuma una importancia creciente en el desarrollo del derecho medioambiental. Eso produce un desplazamiento del interés colectivo preponderante, desde la evitación de ciertos efectos sobre los recursos naturales, identificados por el poder estatal conforme a cierto conocimiento, hacia la evitación de la distorsión de los presupuestos cognitivos que validan los procesos de generación, exposición e intercambio de conocimiento. Este desplazamiento puede tener lugar en el marco de una propuesta radicalmente sustitutiva del esquema de command-and-control, o vincularse a ese esquema como correctivo o complemento ${ }^{25}$. En ambos casos, la protección

${ }^{24}$ Esto es lo que Richard J. Lazarus y Kathleen Brickley describen como "tendencia evolutiva” o "carácter evolutivo" de la legislación medioambiental (Lazarus: "Meeting...”, op. cit., supra, nota 3, p. 2426; Brickley, "Environmental Crime...”, op. cit., supra, nota 3, p. 500).

${ }^{25}$ Su postulación como sustituto del esquema de command-and-control es una de las características del derecho medioambiental de segunda generación según Stewart (“A New Generation...”, op. cit., supra, nota 5, p. 127 s.). 
penal del interés preponderante exige identificarlo como un hecho institucional, en un sentido enteramente análogo a la idea de la fe pública concretada en la punición de aseveraciones falsas en determinados contextos, en vez del hecho bruto en característicamente consiste el daño al medio ambiente.

En un sentido muy general, se puede afirmar que la regulación medioambiental ha sido originariamente aspiracional, esto es, que su surgimiento no ha tenido por objetivo consolidar un estado de cosas socialmente dado, sino por el contrario implementar un programa de cambio dramático de actitudes y comportamiento ${ }^{26}$. En un sentido más preciso, la regulación medioambiental demuestra un carácter aspiracional en tanto sus objetivos prioritarios experimentan un proceso de sustitución como resultado del aseguramiento de su logro. Así, el control de las fuentes capaces de producir la degradación en gran escala de los recursos naturales —en el caso chileno, quizás, la absorción institucional de los proyectos económicos de gran envergadura-, una vez asegurado, es sustituido por objetivos más ambiciosos, como la evitación de contaminación proveniente de fuentes de menor escala, o la coordinación de las distintas instancias estatales de decisión medioambiental en un esquema coherente de asignación de prioridades en la ponderación y control de riesgos ${ }^{27}$. Para la legitimación del reforzamiento penal de la regulación medioambiental que experimenta este proceso, el carácter aspiracional así entendido implica una demanda creciente de justificación del carácter no-compensatorio del objeto de protección. Mientras más se aleje el objetivo de la regulación medioambiental del paradigma representado por la evitación del daño catastrófico, más difícil es sostener que el interés protegido por esa regulación detenta esa posición en la red de intereses merecedores de protección legal.

(iii) Incluso al interior del paradigma de la evitación del daño catastrófico la protección penal de la regulación medioambiental enfrenta una dificultad importante en todos los casos en que ese efecto no es causalmente reconducible a un evento simple. En estos casos, que constituyen el objeto preciso de regulación de las normas de emisión, el nivel de relevancia de la contribución individual al efecto catastrófico tiene lugar bajo el paradigma de la acumulación, es decir, bajo la consideración de la eventual concurrencia de contribuciones múltiples. Fuera de duda parece encontrar-

${ }^{26}$ Así, Lazarus: “Meeting...”, op. cit., supra, nota 3, p. 2424; Brickley, "Environmental Crime...”, op. cit., supra, nota 3, p. 498.

${ }^{27}$ Este proceso es característico del paso de una regulación medioambiental de primera generación a otra de segunda o tercera generación, según Stewart (“A New Generation...”, op. cit., supra, nota 5, p. 27 s. y 151 s.). 
se la suficiencia del paradigma de la acumulación para la legitimación de la norma de comportamiento (la norma de emisión). Lo que es objeto de controversia es su suficiencia para la legitimación de la norma punitiva correlativa (la sanción penal de la infracción de una norma de emisión) ${ }^{28}$.

Esta distinción indica ya que las objeciones formuladas en contra de la punición bajo el paradigma de la acumulación no corresponden a la clase de argumentos que impugnan la legitimidad de las normas penales con apoyo en la concepción del bien jurídico como objeto de protección exclusivo, que conducen por igual a la afirmación de la ilegitimidad de la norma punitiva y la norma de comportamiento correlativa. Las objeciones al paradigma de la acumulación se vinculan al principio de culpabilidad, ya sea directamente (objeción de la punición ex iniuria tertii) o indirectamente, en función del principio de proporcionalidad bajo su concreción de prohibición de exceso respecto del estándar de proporcionalidad stricto sensu reformulada como proporcionalidad retrospectiva. Conforme a estas objeciones, justificar la sanción penal de la infracción de una norma de emisión bajo el paradigma de la acumulación implicaría, o bien atribuir al infractor la responsabilidad por un daño que es causado por la contribución de otros (ex iniuria tertii), o bien imponer una pena por una acción que no es lesiva del bien jurídico protegido y que por lo mismo resulta desproporcionada.

${ }^{28}$ Para una revisión de la controversia en la doctrina alemana, Hefendehl, op. cit., supra, nota 18, p. 183 s.; una versión sintética de su posición personal se encuentra en Hefendehl, Roland: “¿Debe Ocuparse el Derecho Penal de Riesgos Futuros? Bienes Jurídicos Colectivos y Delitos de Peligro Abstracto”, 2001, p. 147 s. La discusión en la doctrina española ha estado marcada por la influyente postura crítica de Silva Sánchez, Jesús María: La Expansión del Derecho Penal. Aspectos de la Política Criminal en las Sociedades Industriales, 1999b, p. 97 s. El mejor desarrollo de esta postura crítica corresponde a Alcácer Guirao, Rafael: "La Protección del Futuro y los Daños Acumulativos”, 2002, sección 08. Es usual que la discusión sobre el paradigma de la acumulación se asocie a la cuestión de la justificación de normas punitivas en virtud de un deber de solidaridad para con las generaciones futuras. Esa asociación es sin embargo contingente: dependiendo del pronóstico que se tenga respecto de las eventuales contribuciones individuales el paradigma de la acumulación requerirá o no proyección transgeneracional para la consideración de la relevancia actual de una contribución. Esto distingue el sentido de “acumulación” propio de este paradigma de otro sentido de “acumulación”, también relevante en este contexto, acuñado por Hans Jonas para identificar los efectos de la intervención tecnológica sobre el mundo como fenómeno que altera los presupuestos de la reflexión ética. Se trata del hecho de la sucesión continua de transformaciones de la situación éticamente problemática, que la hacen progresivamente diferente. Este rasgo exige, según Jonas, que la deliberación acerca de la corrección de la acción en la situación actual incluya una consideración de sus efectos sobre la definición de la situación futura. Aquí se encontraría una diferencia central de la ética de la civilización tecnológica respecto de la ética clásica (Jonas, Hans: El Principio Responsabilidad, 1995, pp. 32-34). Como salta a la vista, este sentido de "acumulación" sí se encuentra necesariamente vinculado con la cuestión de la consideración debida a las generaciones futuras. 
La defensa del paradigma de la acumulación se basa en la tesis de que él ofrece un equivalente material al paradigma de la causalidad lesiva — propio de la constatación de la afectación de bienes individuales_-, que resulta necesario para constatar la relevancia de la contribución de una acción individual a la afectación de bienes colectivos ${ }^{29}$. Contra la objeción de la punición ex iniuria tertii, se observa que ella confunde el nivel de fundamentación de la ley penal con el nivel de aplicación de la ley penal. El paradigma de la acumulación no implica la imputación al infractor de la norma de emisión del daño medioambiental masivo que se busca evitar, sino justificar la relevancia de su contribución individual; eso — su propia contribución - es todo lo que se le imputa como acción típica. La observación es correcta en el sentido trivial de que el objeto de imputación se encuentra definido por la norma de comportamiento. Pero no alcanza el sentido de la objeción, que sólo queda suficientemente expresado en la forma de dilema: a menos que se pueda imputar a la acción individual un margen significativo de afectación del medio ambiente, la aplicación de una pena privativa de libertad es desproporcionada; dado que no puede imputarse — por definición- el margen significativo bajo el paradigma de la causalidad lesiva, o bien se lo imputa encubiertamente ex iniuria tertii o bien hay exceso punitivo. El núcleo de la objeción se encuentra en el argumento de la desproporción ${ }^{30}$.

La defensa del paradigma de la acumulación tiene que hacerse cargo del dilema y negar la premisa de la objeción, esto es, o bien negar que el derecho constitucional exige al legislador satisfacer un estándar de proporcionalidad particularmente selectivo de las variables en ponderación con la pena (es decir, redefinido retrospectivamente), o bien negar que ese estándar supone la constatación de una equivalencia cándida entre la acción

${ }^{29}$ En el ámbito de la filosofía moral anglonorteamericana, el lugar clásico de esta defensa se encuentra en Feinberg, op. cit. supra, nota 17, p. 225 s.; en el ámbito de la dogmática penal alemana cuenta como lugar clásico Kuhlen, op. cit. supra, nota 3, especialmente p. 711 s.; en el ámbito de la dogmática de habla castellana, cabe mencionar la crítica al planteamiento de Alcácer Girao efectuada por Mañalich, Juan Pablo: "La Protección del Medio Ambiente bajo el Nuevo Código Penal de Puerto Rico”, 2006, p. 503.

${ }^{30}$ Correctamente, Silva Sánchez identifica el aspecto problemático de la acumulación en la asimetría existente entre la distribución de la causalidad por el daño total entre las distintas infracciones individuales y la concentración (no-distribuibilidad) de la pena privativa de libertad en cada infractor individual, (op. cit. supra nota 30, p. 112). De otro modo no se entendería que los autores que sostienen esta objeción favorezca el uso de sanciones administrativas o multas penales para asegurar la vigencia de las normas de emisión: también a esas sanciones sería aplicable la objeción de imputación de responsabilidad ex iniuria tertii, si esta objeción no fuera dependiente de la objeción de desproporción. 
estatal (privación de libertad ambulatoria del infractor) y la acción del infractor (contribución causalmente lesiva de un bien equivalente). La primera alternativa conduce a la relativización del rol que desempeña el principio de culpabilidad en la configuración de la práctica punitiva como modo específico de coacción estatal. La segunda exige a la superación de un retribucionismo ingenuo ${ }^{31}$ por una asunción más sofisticada del principio de culpabilidad, ya sea en el contexto de una matriz conceptual retribucionista o moderadamente utilitarista. A menos que quiera renunciar al principio de culpabilidad, una teoría dualista del bien jurídico, es decir, una teoría que pretenda ofrecer criterios de legitimación de la punición de acciones individuales como atentados contra bienes colectivos, tiene que superar la idea de que el principio de proporcionalidad stricto sensu exige esa equivalencia cándida entre acción punible y pena.

Decisiva resulta en este contexto la observación de Feinberg, en orden a que la legitimación de la consideración de las emisiones contaminantes como acciones dañinas, conforme al principio de proporcionalidad bajo el paradigma de la acumulación, sólo tiene sentido sobre el trasfondo de un sistema regulativo que controla que las emisiones se mantengan en conjunto bajo el umbral del daño total, restringiendo en el mínimo posible las actividades socialmente valiosas que constituyen fuentes de emisión ${ }^{32}$. Sobre ese trasfondo, "dañino" sólo puede significar que la contribución al daño total es superior al nivel permitido en razón de su valor social, lo que supone un esquema de distribución de prioridades institucionalmente operativo. La satisfacción del principio de proporcionalidad bajo el paradigma de la acumulación conduce, por lo tanto, al mismo resultado a que conducía el reconocimiento de la relatividad de la protección penal del medio ambiente: la necesaria dependencia en que se encuentra la regulación penal de la regulación administrativa ${ }^{33}$.

${ }^{31}$ En el sentido de la conocida objeción de Hegel a la concepción del retribucionismo mantenida por Ernst Ferdinand Klein, según el cual delito y pena eran simplemente casos de perjuicio, con la consiguiente imposibilidad de que en ese plano empírico de referencia del perjuicio que sigue a un perjuicio previo resulte un bien (Hegel: Principios de la Filosofía del Derecho, Observación al §99, 1988, p. 160).

32 En sus propias palabras: "No hay nada inherentemente malo o que viole derechos en la acción de conducir un automóvil, o en las actividades de generar electricidad o refinar cobre. Estas actividades sólo se pueden condenar fundadamente como violaciones de un plan oficial de prioridades asignadas.” (Feinberg, op. cit. supra nota 17, p. 230). Para una aplicación del concepto de daño a los distintos contextos de la regulación medioambiental, validando el paradigma de la acumulación, Lin, Albert C.: "The Unifying Role of Harm in Environmental Law”, 2006.

${ }^{33}$ Queda siempre en pie la plausibilidad de una objeción al uso de sanciones penales o de penas privativas de libertad como infracción a la prohibición de exceso respecto del estándar de necesidad racional, es decir, del carácter estrictamente subsidiario 


\section{La dependencia del derecho penal del medio ambiente de la regulación administrativa}

Tal como se ha podido apreciar en la sección anterior, la variedad de relaciones posibles entre el derecho penal del medio ambiente y el derecho administrativo del medio ambiente se encuentra asociada a otras consideraciones relativas a los fines y condiciones de legitimación de la ley penal. Por esta razón, la construcción de tipologías de relaciones entre norma penal y norma administrativa puede atender preferentemente a estas otras consideraciones $^{34}$. Recíprocamente, la construcción de una tipología que atienda preferentemente a la clase de relaciones entre normas punitivas y normas regulativas debe correlacionar esos tipos de relaciones con las demás consideraciones relevantes. Este es el caso de la tipología construida por Günther Heine y seguida en la doctrina española por Norberto de la Mata, que distingue tres modelos: el modelo de la regulación penal absolutamente independiente de la regulación administrativa, el modelo de la regulación penal absolutamente dependiente de la regulación administrativa y el modelo de la regulación penal relativamente dependiente de la regulación administrativa ${ }^{35}$. En cada uno de estos modelos, el tipo de relación con el derecho administrativo se encuentra vinculado a una definición del bien jurídico preferentemente protegido por el derecho penal que adopta ese modelo.

El modelo de independencia absoluta pretende que la norma de comportamiento medioambiental sea definible a partir de la sola norma punitiva, como su correlato de sentido. Este modelo es funcional a la configuración de delitos de peligro concreto para la vida o la salud de las personas o a la configuración de delitos de grave daño ambiental, en un sentido relevante

del derecho penal. Pero esta es una objeción derivada del principio de proporcionalidad como estándar de legitimación general del derecho público y su peso depende de la apreciación de la idoneidad comparativa de los medios disponibles alternativos al derecho penal. Un ejemplo de exceso en este sentido se encuentra en el Art. 170 AP, como se expondrá más adelante (secciones 7 y 11).

${ }^{34}$ Tal es el caso de la tipología elaborada por Faure y Visser (op. cit., supra, nota 3), que tomando como cuestión central de análisis la clase de evidencia requerida para imputar responsabilidad, atiende preferentemente a la caracterización de delito tipificado en relación con la afectación del bien jurídico protegido, distinguiendo en consecuencia entre modelos de peligro abstracto (A), peligro concreto (B), contaminación seria (C) y vaguedad regulativa (D). Esta es la tipología seguida por Cho, Byung-Sun: "El Surgimiento de un Derecho Penal Internacional del Medio Ambiente”, 2001, p. 3 s., especialmente p. 9 s., que a su vez sirve de referente para la decisión del proyecto de adoptar como modelo regulativo el del serio daño medioambiental (Matus (ed.), op. cit. supra, nota 2, p. 124 s.).

${ }^{35}$ Heine, Günter: “Accesoriedad Administrativa en el Derecho Penal del Medio Ambiente”, 1993, p. 289 s.; De la Mata Barranco, Norberto: Protección Penal del Ambiente y Accesoriedad Administrativa., 1996, p. 61 s. 
para el paradigma de la causalidad lesiva. El modelo de dependencia absoluta prescinde de configurar una norma de comportamiento medioambiental como correlato de sentido de la norma punitiva, remitiéndose ésta por completo - como ley penal totalmente en blanco— - a la regulación administrativa. Este modelo es funcional a la configuración de delitos de mera desobediencia a la autoridad. Finalmente, el modelo de dependencia relativa atribuye a la norma punitiva una función relevante para la identificación de la norma de comportamiento medioambiental, pero se remite a la regulación administrativa como complemento para su definición. Este modelo es funcional a la configuración de delitos de peligro abstracto para el medio ambiente en un sentido relevante para el paradigma de la acumulación.

La opción por el modelo de la dependencia absoluta es, obviamente, la vía más fácil para el legislador. Es el modelo característico de la legislación penal especial medioambiental, particularmente relevante en el surgimiento del derecho medioambiental norteamericano ${ }^{36}$. En el nivel del derecho administrativo sancionador es una técnica seguida entre nosotros por el derecho sanitario y la regulación medioambiental más directamente relacionada con é $\mathbf{l}^{37}$. Sin embargo, difícilmente podría considerárselo como una alternativa viable para el establecimiento en el sistema jurídico chileno de un derecho penal medioambiental que prevea penas privativas de libertad. Independientemente de los reparos que su falta de selectividad merezca a la luz del principio de proporcionalidad, un modelo de dependencia absoluta, es decir, de configuración de normas punitivas como leyes totalmente en blanco, no podría satisfacer el mandato de determinación derivado del principio de legalidad, al menos no en su versión por la jurisprudencia del Tribunal Constitucional ${ }^{38}$.

${ }^{36}$ Críticamente, Lazarus, “Assimilating...”, op. cit., supra, nota 3, p. 881 s.

${ }^{37}$ El Art. 147 del Código Sanitario establece una sanción general de multa para "la infracción de cualquiera de las disposiciones de este Código o de sus reglamentos o de las resoluciones que dicten los Directores de los Servicios de Salud o el Director del Instituto de Salud Pública”. Siguiendo ese modelo, el Art. 85 del Reglamento Sanitario sobre Manejo de Residuos Peligrosos (D.S. No 148, de 2004) autoriza a la autoridad sanitaria para sancionar "las infracciones al presente reglamento".

${ }^{38}$ Como es sabido, basándose en la constatación de una diferencia entre la disposición originariamente aprobada por la Comisión de Estudios de la Nueva Constitución para el actual Art. 19 No 3 inciso final, que exigía del precepto legal la descripción "completa” y "expresa" del comportamiento constitutivo de delito, y la disposición que en definitiva quedó incorporada en la Constitución, que sólo exige descripción expresa del comportamiento en la ley penal, el Tribunal Constitucional admite la validez constitucional de la remisión legal a la regulación administrativa, cuando ésta tiene carácter complementario. La tesis jurisprudencial tempranamente afirmada en la sentencia de 4 de diciembre de 1984 (Rol $\mathrm{N}^{\circ}$ 24-1994), ha sido recientemente confirmada para el ámbito del derecho administrativo sancionador por la sentencia de 27 de julio de 2006 (Rol No 480-2006). 
Para un futuro derecho penal del medio ambiente las opciones parecen reducirse, por lo tanto, a los otros dos modelos. Como resulta obvio, la asignación de peso a las objeciones formuladas al paradigma de la acumulación y el interés por reducir al máximo posible el riesgo de no satisfacer las exigencias del mandato de determinación derivado del principio de legalidad son razones para optar por el modelo de independencia absoluta. Ambas consideraciones desempeñan un papel relevante en la propuesta regulativa del proyecto y el anteproyecto. Ninguna de ellas constituye, sin embargo, una razón suficiente para prescindir del único modelo capaz de brindar la protección penal del medio ambiente requerida por el derecho medioambiental, que es el modelo de la dependencia relativa.

De todas las razones a favor de este modelo, la más relevante en este contexto es precisamente la optimización de las exigencias del principio de legalidad. Si bien es cierto que la remisión de la ley penal al derecho administrativo entra en tensión con el fundamento democrático del principio de legalidad, que exige entender la garantía como reserva parlamentaria, no puede desconocerse que esa remisión representa la mejor vía institucional para satisfacer el propio mandato de determinación desde el punto de vista de su fundamento liberal ${ }^{39}$. La remisión a la regulación administrativa preserva la exigencia del principio de legalidad de que la norma de comportamiento tenga existencia pragmática de carácter convencional, es decir, sea formulada de modo deliberado y exhaustivo, fijada en un texto autoritativo y dotada de una fecha cierta de comienzo de vigencia. Ello es así, porque la alternativa a esta remisión no es la fijación en la ley penal de una norma equivalente en su precisión al complemento normativo administrativo. La única alternativa posible a la remisión al derecho administrativo, en el modelo de la independencia absoluta, es el uso de cláusulas generales o conceptos indeterminados. El uso de cláusulas de esta índole implica una técnica regulativa aun más deficiente a la luz del principio de legalidad, pues implica transferir la decisión del órgano regulador al órgano adjudicador.

La propia estructura del sistema institucional que produce la regulación medioambiental demuestra, por lo demás, cuán inidónea resulta la transferencia de la competencia decisoria desde la regulación hacia la adjudicación. Los tribunales carecen de los conocimientos técnicos necesarios para concretar las normas indeterminadas y en cada caso el acusado podría sostener — con razón- que al momento de su acción no podía conocer la norma resultante de la concreción judicial ex-post. La única manera de fijar

${ }^{39}$ Para un vistazo sumario a los distintos fundamentos de justicia política del principio de legalidad, Roxin, Claus: Strafrecht. Allgemeiner Teil (Derecho Penal. Parte General), Tomo I, 1997, p. 92 s. (versión en español de la $1^{\text {a }}$ ed. bajo ese título en Editorial Civitas, Madrid, 1997, p. 134 s.). 
ex-ante estándares inelásticos de respeto a los bienes colectivos, particularmente al medio ambiente, es mediante la regulación administrativa ${ }^{40}$.

\section{El tratamiento sistemático de los delitos contra el medio ambiente en el anteproyecto}

El anteproyecto trata a los "delitos relativos al medio ambiente" dentro de un título - libro ii, título ix - dedicado a los "delitos de peligro común”. El concepto de peligro común alude a uno de los dos sentidos en los cuales se puede decir de un interés que es público o colectivo, según Feinberg ${ }^{41}$. El sentido más intuitivo con que se concibe a un interés como colectivo es entendiéndolo como un interés específico común o ampliamente compartido, o, si se quiere como el interés que todos o casi todos tienen en un mismo objeto. Este es el sentido con que se ha discutido en la segunda sección de este trabajo la condición del medio ambiente como bien jurídico susceptible de legítima protección por el derecho penal.

El concepto de "peligro común” designa, sin embargo, precisamente el otro sentido en que se afirma la calidad de público o colectivo de un interés. Este es el caso de una colección de múltiples intereses específicos de la misma clase poseídos por un número amplio o indefinido de individuos; no se trata de un interés que pertenezca a todos, sino de intereses que pertenecen cualquiera. En este sentido, el daño público o colectivo es el producido por una actividad que es en general peligrosa, es decir, que no pone en peligro a alguien individualizable, sino a cualquiera que se encuentre en la situación de verse afectado. El peligro común a que alude el título ix del libro ii del anteproyecto es precisamente el generado por esa clase de actividad.

El ejemplo clásico de delito de peligro común es el delito de incendio $^{42}$. A dicho ejemplo pueden agregarse, en el nivel del Código Penal chileno, los delitos contra la salud pública (especialmente los previstos en los Arts. 313-(d) a 317) y algunos de los delitos relativos a ferrocarriles (Arts. 323, 330). Varias de las disposiciones contempladas en el título ix del libro ii del anteproyecto tipifican delitos de esta clase. Así, por ejemplo, la realiza-

${ }^{40}$ Este es el argumento de Günther Jakobs para contrarrestar las dudas en torno a la legitimidad de los delitos contra el medio ambiente (¿Qué Protege el Derecho Penal: Bienes Jurídicos o la Vigencia de la Norma?, 2001, p. 47 s.).

${ }^{41}$ Feinberg: Harm to Others, op. cit. supra nota 17, pp. 222-224.

${ }^{42}$ De aquí que el Código Penal, si bien lo trata sistemáticamente como delito contra la propiedad, establezca una regla —incompatible con ese tratamiento- conforme a la cual también constituye incendio punible el cometido en cosa propia (Art. 482). 
ción de acciones que puedan propagar enfermedades para animales o vegetales (Arts. 177-179), las hipótesis de incendio (Arts. 182-186), las hipótesis equivalentes a los actuales delitos contra la salud pública (Arts. 192-197) y las hipótesis de peligro en el transporte (Arts. 215-227).

Es claro, sin embargo, que el anteproyecto no se limita a tratar auténticos delitos de peligro común en este título, sino que incluye en él figuras que no responden a esa idea sistemática. En algunos casos se trata de delitos contra intereses colectivos en el primer sentido indicado, como las reglas que buscan brindar protección a especies animales o vegetales amenazadas de extinción o reforzar situaciones de especial protección administrativa de la fauna o la flora (Arts. 174-175, 181, 190). En otros casos se trata de delitos cuya finalidad de protección parece no ser clara para los redactores del anteproyecto, como el maltrato de animales (Art. 180). En otros casos, finalmente, la apelación a la idea de un peligro común no es más que una excusa para ocultar la posición paternalista o moralizante del anteproyecto, como en los delitos de clonación y fecundación técnicamente asistida (Art. $191 \mathrm{~N}^{\circ} 2$ y 3) y de tráfico y consumo de estupefacientes (Arts. 200 a 214).

Tratándose de los delitos relativos al medio ambiente, si su inclusión en este título obedeciera rigurosamente a una decisión de política legislativa, ello implicaría que la alteración del medio ambiente nunca podría ser considerada como una acción en sí misma merecedora de pena. Tratar coherentemente a los delitos relativos al medio ambiente como delitos de peligro común implica sostener la tesis de que la alteración al medio ambiente sólo puede ser considerada como merecedora de pena en la medida en ella ponga en peligro intereses individuales poseídos por un número indefinido de individuos, como la vida, la integridad corporal o la propiedad. Esta es, como se ha visto, la idea central del Proyecto Alternativo alemán: considerar al medio ambiente como una posible fuente de peligro para las personas $^{43}$

En el anteproyecto, sin embargo, la caracterización de los delitos relativos al medio ambiente como delitos de peligro común es puramente nominal.

La mayor parte de las hipótesis tipificadas por el anteproyecto como delitos relativos al medio ambiente constituyen atentados contra el medio ambiente, ya sea en grado de lesión (Art. 167 inciso primero, Art. 168 inciso primero, Art. 169), de peligro concreto (Art. 171 inciso primero) o de peligro abstracto (Art. 170), con total independencia de si esos atentados representan una puesta en peligro de los intereses individuales que podrían verse

\footnotetext{
${ }^{43}$ Véase supra, nota 16.
} 
afectados. En todas estas hipótesis, por lo tanto, el anteproyecto considera al medio ambiente como un bien jurídico colectivo en el primer sentido indicado. Esta era, naturalmente, la finalidad perseguida por el proyecto: proteger el medio ambiente, ya sea directamente frente a atentados graves, o indirectamente mediante el aseguramiento de las condiciones de operatividad del sistema de evaluación de impacto ambiental ${ }^{44}$. El anteproyecto mantiene esa decisión de política criminal, pero elude explicitarla, presentándola bajo una consideración sistemática incompatible.

Por otra parte, en los casos en que el proyecto agrava la pena de los atentados al medio ambiente por ocasionar resultados de peligro concreto para la vida o la salud de las personas, tampoco parece la concepción del peligro común. El anteproyecto sólo agrava la pena de los atentados al medio ambiente cuando ellos ponen en serio peligro la vida o la salud de personas determinadas (Arts. 167 inciso primero, 168 inciso segundo, 169, 171 inciso segundo). Con eso el anteproyecto configura las hipótesis calificadas por el peligro como supuestos de peligro concreto para la vida o la salud, en un sentido indiferenciable de la protección de esos bienes en tanto intereses individuales. Pero si algún sentido tiene la concepción de delito de peligro común es precisamente la de rebasar ese umbral, derivando en delitos de peligro abstracto stricto sensu o en delitos de peligrosidad o de idoneidad peligrosa respecto de víctimas indeterminadas ${ }^{45}$.

${ }^{44}$ Matus (ed.), op. cit. supra nota 2, pp. 229-230.

${ }^{45}$ Por esta razón, para hacer efectivo el planteamiento ya expresado en la fundamentación del Proyecto Gubernativo alemán de 1962, en el sentido de no hacer depender la penalidad del responsable por la acción peligrosa de la cuestión puramente casual de si alguien en concreto queda o no expuesto, el Proyecto Alternativo alemán prescindió de la fórmula "pone en peligro el cuerpo o la vida de alguien”, sustituyéndola por la fórmula "sin que al momento de la acción deba excluirse la causación de daño a otro en su cuerpo o su vida” ( $\$ 151-1 \mathrm{AE}$ ). En los propios términos de sus redactores: "Cuando conforme a esto un bien jurídico pudo ser puesto en peligro al momento de la acción, el autor es punible, aun cuando en realidad ningún bien jurídico haya estado en peligro, porque lo impidió una casualidad. Lo decisivo es el juicio de un observador objetivo al momento de la realización de la acción; la apreciación subjetiva por parte del autor sólo es relevante en el marco del dolo y la imprudencia" (Alternativ-Entwurf, op cit. supra, nota 16, p. 57; lo remarcado es del original). Esta definición del delito como un supuesto que puede poner en peligro un bien jurídico, sin necesidad de constatar que en el caso concreto ese bien haya sido efectivamente puesto en peligro, es lo que caracteriza al delito de peligrosidad, de peligro hipotético o de aptitud o idoneidad peligrosa, por contraste con el delito de peligro concreto (más exigente) y el delito de peligro abstracto stricto sensu (menos exigente). Acerca de esta distinción, con ulteriores referencias, Mendoza Buero, Blanca: "El Delito Ecológico: Configuración Típica, Estructuras y Modelos de Tipificación”, 2005, especialmente p. 127 s. 
En resumen, el tratamiento sistemático nominalmente dado por el anteproyecto a estos delitos es doblemente inconsistente. A pesar de su declaración en el epígrafe del título respectivo, lo cierto es que no tipifica los delitos relativos al medio ambiente como delitos de peligro común. El anteproyecto los tipifica como delitos contra el medio ambiente, agravando su pena cuando además constituyen supuestos de peligro —o lesión- a los intereses individuales de la vida y la salud de las personas ${ }^{46}$.

\section{La regulación de los delitos de atentado al medio ambiente}

El anteproyecto establece tres hipótesis de atentados al medio ambiente o delitos de contaminación (Arts. 167, 168, 169 AP). En esta sección serán examinadas sus dos figuras centrales (Arts. 167 y 168 AP). Estas figuras se encuentran configuradas de modo paralelo, diferenciándose en atención al criterio de imputación subjetiva del resultado de grave daño al medio ambiente: la comisión dolosa (Art. 167) y la comisión imprudente (Art. 168). La estructura de ambas figuras casi por entero idéntica. Ambas parten de una hipótesis básica — “producir un grave daño ambiental”- y establecen hipótesis calificadas por la producción de resultados ulteriores más graves: puesta en serio peligro para la vida o salud de personas determinadas, producción de lesiones corporales a una o más personas, producción de muerte a una o más personas ${ }^{47}$.

${ }^{46} \mathrm{La}$ inconsistencia procede exclusivamente de las decisiones del anteproyecto. En el contexto del proyecto, pensado como legislación penal especial, no se planteaba la cuestión de otro criterio de identificación del bien jurídico que no fuera el medio ambiente considerado como un bien colectivo en el primer sentido indicado. Asimismo las disposiciones del proyecto que agravaban la pena de los delitos contra el medio ambiente por la creación de un peligro tipificaban la hipótesis usando la fórmula "si pusiere en serio peligro la vida o la salud de las personas" (Art. $1^{\circ}$ inciso segundo, Art. $2^{\circ}$ inciso primero, Art. $3^{\circ}$ inciso segundo). La exigencia de que debe tratarse de personas "determinadas" fue introducida por el anteproyecto. Puede estarse de acuerdo o en desacuerdo con esta decisión; lo que está fuera de toda duda es la impropiedad de caracterizar un peligro así precisado como "peligro común".

${ }^{47} \mathrm{La}$ escala de penalidades tiene la siguiente estructura:

- 5 años y 1 día a 15 años de reclusión y multa de 7.000 a 10.000 UTM: comisión dolosa de grave daño ambiental que produce la muerte de una o más personas;

- 3 años y 1 día a 10 años de reclusión y multa de 5.000 a 7.000 UTM: comisión dolosa de grave daño ambiental que produce lesiones corporales gravísimas a una o más personas;

- 3 años y 1 día a 5 años de reclusión y multa de 4.000 a 5.000 UTM: comisión dolosa de grave daño ambiental que produce lesiones menos graves o simplemente graves a una o más personas; 
En relación con la hipótesis básica es necesario considerar la determinación del objeto y el modo de ataque (5.1) y la determinación del resultado (5.2). En relación con las hipótesis calificadas cabe analizar por separado la puesta en peligro (5.3) y la producción de lesiones o muerte (5.4).

\subsection{La determinación del objeto y el modo de ataque en el atentado al medio ambiente}

Cuando la protección penal del medio ambiente se establece en la legislación especial, con el carácter de disposiciones específicamente punitivas consagradas en leyes medioambientales de carácter más general, la cuestión de la determinación del objeto y el modo de ataque del atentado al medio ambiente viene resuelta por el propio contexto regulativo. Este es el caso, por ejemplo, del derecho penal medioambiental federal norteamerica$\mathrm{no}^{48}$. Cuando, por el contrario, se pretende dispensar la protección penal en una única ley penal especial — como es el caso del proyecto- o en el Código Penal — como es el caso del anteproyecto-, la ausencia de un marco contextual de referencia exige ser compensada en el diseño de la propia regulación penal.

En este último contexto, además, la regulación penal se ve más intensamente expuesta a la tensión existente entre la disparidad de la regulación medioambiental sectorial, originada por la variedad de componentes del medio ambiente protegidos y sus posibles modos de afectación, y la preten-

- 3 años y 1 día a 5 años de reclusión y multa no inferior a 3.000 UTM: comisión imprudente de grave daño ambiental que produce la muerte a una o más personas;

- 3 años de reclusión y multa de 3.000 a 5.000 UTM: comisión dolosa de grave daño ambiental que pone en serio peligro la vida o la salud de personas determinadas;

- 541 días a 3 años de reclusión y multa no inferior a 3.000 UTM: comisión imprudente de grave daño ambiental que produce lesiones menos graves o simplemente graves a una o más personas;

- 541 días a 3 años de reclusión y multa de 2.000 a 3.000 UTM: comisión dolosa de grave daño ambiental;

- 61 días a 3 años de reclusión (y multa de 2.000 a UTM 4.000): comisión imprudente de grave daño ambiental que pone en serio peligro la vida o la salud de personas determinadas;

- 61 a 540 días de reclusión y multa de 2.000 a UTM 4.000: comisión imprudente de grave daño ambiental.

La simetría entre la escala de penalidades del Art. 167 y la del Art. 168 se rompe en un solo punto: el Art. 168 no contempla —seguramente por inadvertencia- una hipótesis calificada por la producción del resultado de lesiones gravísimas a una o más personas.

${ }^{48}$ Para un vistazo de conjunto, "Environmental Crimes" (nota editorial), American Criminal Law Review, 42 (2005), p. 347. 
sión de armonización de su protección penal. El caso español y el caso alemán representan los dos modelos contrapuestos de tratamiento legislativo de esta tensión. El Art. 325 N 1 CP español otorga un mismo trato penal a diversas formas de atentado contra diversos componentes del medio ambiente, limitándose a una enumeración más o menos casuística de esos atentados y dejando enteramente entregada a la regulación administrativa — las "leyes u otras disposiciones de carácter general protectoras del medio ambiente”- la determinación precisa de su ilicitud ${ }^{49}$. Por contraste, el Código Penal alemán distingue entre la contaminación del agua (§ 324), la contaminación del suelo (§ 324-a), la contaminación del aire (§ 325) y la emisión de ruidos, vibraciones y radiaciones no ionizantes ( $\S 325-a)$, definiendo en cada caso las condiciones bajo las cuales la emisión contaminante es merecedora de pena ${ }^{50}$. Este rasgo fue asumido explícitamente por el legislador alemán como una realización deficitaria de la pretensión de armonización justificada por la necesidad de mantener una adecuada conexión sistemática entre las normas del Código Penal y las normas de la legislación medioambiental correlativas ${ }^{51}$.

Este es, probablemente, el punto crítico de cualquier propuesta de protección penal del medio ambiente en el contexto del derecho chileno. Aparte de la estructura administrativa que la Ley 19300 superpuso a las diversas competencias administrativas preexistentes para la gestión medioambiental, el legislador penal no dispone de un marco de referencia legal unificado, ni siquiera sectorialmente ${ }^{52}$. En estas circunstancias, la adopción

${ }^{49} \mathrm{El} \mathrm{Art}$. $325 \mathrm{~N}^{\mathrm{o}} 1$ sanciona al "que (...) provoque o realice directa o indirectamente emisiones, vertidos, radiaciones, extracciones o excavaciones, aterramientos, ruidos, vibraciones, inyecciones o depósitos, en la atmósfera, el suelo, el subsuelo o las aguas terrestres, marítimas o subterráneas, con incidencia, incluso, en los espacios transfronterizos (...)”. A esta enumeración se agrega, en el mismo $\mathrm{N}^{\circ} 1$ la captación de aguas que pueda perjudicar gravemente el equilibrio de los sistemas naturales, y en el $\mathrm{N}^{\mathrm{o}} 2$, con una pena más severa, la emisión de radiaciones ionizantes.

50 Así, la contaminación del agua es punible cuando constituye una alteración perjudicial de sus propiedades; la contaminación del suelo, en cambio, cuando se realiza de un modo apto para dañar la salud de las personas, o animales, plantas, cosas de valor significativo o aguas, o bien cuando se lo contamina o altera perjudicialmente en una medida significativa; la contaminación del aire, cuando se realiza del modo peligroso antedicho, o bien cuando tiene lugar mediante la liberación en gran cantidad de material dañino; la emisión de ruido, vibraciones o radiaciones no ionizantes, finalmente, sólo es punible cuando pone en peligro la salud de las personas, animales o cosas de valor significativo.

${ }^{51}$ Al respecto, Steindorf, op. cit., supra nota 3, pp. 24-26.

52 Para un vistazo de la regulación legal y reglamentaria relevante, clasificada según el medio o recurso (suelo, aire, agua, biodiversidad, medio urbano), Fernández Bitterlich, Pedro: Manual de Derecho Ambiental, 2001, p. 217 s. 
del modelo alemán exigiría un esfuerzo regulativo extraordinario y la adopción del modelo español conspiraría contra la operatividad de las normas penales, además de los reparos que podría merecer desde el punto de vista del mandato de determinación derivado del principio de legalidad.

La respuesta que da el anteproyecto a esta cuestión — que en esto sigue íntegramente al proyecto — se presenta como la solución de un nudo gordiano: el anteproyecto prescinde de cualquier descripción concreta del objeto de ataque así como de cualquier descripción concreta del modo o medio de ataque, dejando ambas materias íntegramente a cargo de una decisión administrativa. Conforme al anteproyecto un reglamento especial debe determinar qué aspecto del medio ambiente es el alterado por la producción de un resultado de "grave contaminación” y qué sustancia o elemento emitido es el que cuenta como producción de ese resultado (Art. 172 AP, Art. $\left.8^{\circ} \mathrm{P}\right)$.

La única decisión adoptada por la regulación penal a este respecto consiste en restringir el ámbito de protección penal del medio ambiente a la prohibición de atentados que sean constitutivos de emisiones reguladas por las normas de emisión del sistema administrativo medioambiental. Tanto el proyecto como el anteproyecto limitan el posible contenido de ese reglamento especial, exigiendo que establezca normas especiales de emisión determinadas en función del nivel de emisión prohibido por las normas generales de emisión. Sobre esto se volverá en la próxima subsección. Lo que aquí interesa es advertir que esta definición del ámbito de la regulación penal como idéntico al ámbito de las normas generales de emisión es por una parte demasiado estrecho y por la otra demasiado amplio.

Es una definición indebidamente estrecha porque deja fuera del ámbito de alcance de las normas penales todas las acciones contaminantes que no consistan en la emisión de las sustancias o elementos que están cubiertos por una norma general de emisión. Todo el ámbito de protección del medio ambiente que la regulación administrativa defina mediante instrumentos institucionales distintos de las normas de emisión queda con ello por definición privado de protección penal frente a atentados contaminantes. No se advierte, sin embargo, por qué habrían de quedar fuera del ámbito de las prohibiciones penales, por ejemplo, los atentados al medio ambiente cometidos con infracción a prohibiciones establecidas en una resolución que aprueba un proyecto bajo el sistema de evaluación de impacto ambiental (Art. 25 Ley 19300) o en planes de prevención o descontaminación (Arts. 44-46 Ley 19300).

Es por otra parte una definición indebidamente amplia, porque no efectúa distinción alguna entre los distintos componentes del medio am- 
biente susceptibles de afectación o las distintas clases de acciones o medios contaminantes. Una regulación tan indiferenciada es criticable precisamente en atención a la principal finalidad perseguida por el proyecto y el anteproyecto, esto es, la pretensión de configurar una regulación penal que utilice criterios selectivos y restrictivos de delimitación de la ilicitud jurídico-penalmente relevante en relación con el ámbito general de la ilicitud medioambiental. En el contexto del anteproyecto, la determinación por la autoridad administrativa del nivel de "grave daño ambiental” debe determinarse exclusivamente en función de los máximos señalados en las respectivas normas de emisión (Art. 172 inciso segundo AP). Si la autoridad administrativa cumpliera este mandato de regulación complementaria respecto de las normas de emisión medioambientales actualmente vigentes, quedarían sujetas a una misma pena conforme al anteproyecto las emisiones por sobre un determinado umbral de elementos tan disímiles como, por una parte, los residuos líquidos vertidos a aguas subterráneas ${ }^{53}$ o a aguas marinas o continentales superficiales ${ }^{54}$, y por otra parte la luz por la noche en las regiones ii, iii y iv ${ }^{55}$.

Una regulación punitiva seriamente preocupada de satisfacer exigencias de proporcionalidad y rigurosa selectividad de merecimiento de protección penal no puede desentenderse de efectuar una diferenciación entre la afectación del agua, el suelo y el aire por emisiones significativas bajo el paradigma de la acumulación, y la emisión de ruido, olor, luz o radiaciones no ionizantes. Tratándose de estas últimas emisiones, su merecimiento de pena debe depender de la puesta en peligro de otros bienes; desde luego la vida y la salud de las personas, pero también la subsistencia de animales, vegetales y otras cosas de valor. La afectación transitoria de la calidad de vida de los afectados por la infracción de máximos permitidos de emisión debe quedar exclusivamente a cargo de la sanción administrativa.

Puede discutirse a este respecto si la mejor manera de concretar esa diferenciación es restringiendo la intervención regulativa complementaria de la administración sólo a la definición del umbral de emisión para el primer grupo, o confiándole, además, la definición de la situación de peligro para el segundo grupo. Lo fundamental es una decisión legal de diferenciación del merecimiento de protección penal.

${ }^{53}$ D.S. N ${ }^{\circ} 46$, de 2002, del Ministerio Secretaría General de la Presidencia (D.O. de 17 de enero de 2003).

${ }^{54}$ D.S. N ${ }^{\circ}$ 90, de 2000, del Ministerio Secretaría General de la Presidencia (D.O. de 7 de marzo de 2001).

${ }^{55}$ D.S. N ${ }^{\circ}$ 686, de 1998, del Ministerio Secretaría General de la Presidencia (D.O. de 2 de agosto de 1999). 


\subsection{La determinación del grave daño para el medio ambiente}

Consciente de las objeciones planteadas a la punición de acciones contaminantes bajo el paradigma de la acumulación, el proyecto se propone "sortear” esas “críticas y dificultades”...

...limitando el castigo penal a graves y fácilmente comprobables actos de contaminación (...) [así] la ley se hace al mismo tiempo aprehensible para el ciudadano común (...), no atribuyéndose al mismo tiempo la imposible tarea de prevenir todos los atentados al ambiente, sino la más modesta de aplicar un castigo proporcional y racional a quien (...) ha causado una grave contaminación ${ }^{56}$.

La manera con que el proyecto pretende determinar la gravedad del daño ambiental consiste en remitirse a un reglamento, al cual se ordena fijar la cantidad y proporción de contaminantes provenientes de una misma fuente emisora cuya emisión al medio ambiente contará como grave daño ambiental en el sentido de las normas penales. El proyecto fija el estándar de esa determinación, prohibiéndole al reglamento considerar como grave daño ambiental cantidades o proporciones de sustancias contaminantes inferiores o iguales a los máximos señalados por las normas generales de emisión (Art. $8^{\circ}$ inciso segundo P). El anteproyecto es más exigente, ya que impone al reglamento el deber de fijar para este efecto cantidades o proporciones de sustancias contaminantes "significativamente superiores" a los máximos señalados por las normas generales de emisión (Art. 172 inciso segundo AP).

Esta es una propuesta desconcertante.

El razonamiento que se encuentra en la base de la propuesta es fácil de identificar. Dado que las normas de emisión se fijan por lo general atendiendo al paradigma de la acumulación y dado que la punición de la infracción de normas de emisión así fijadas aparece como desproporcionada desde el punto de vista del paradigma de la causalidad lesiva, lo que el proyecto y el anteproyecto intentan es desplazar el criterio de fijación de la norma de comportamiento jurídico-penalmente relevante desde el paradigma de la acumulación (nivel máximo de la norma de emisión) hacia el paradigma de la causalidad lesiva (nivel no inferior ni igual o nivel significativamente superior a ese máximo).

Se trata de un razonamiento tan fácil de reconocer como difícil de aceptar. El intento de desplazamiento del criterio de fijación de la norma de

\footnotetext{
${ }^{56}$ Matus (ed.), op. cit. supra nota 2, pp. 227-228.
} 
emisión supone que es posible apreciar un estándar continuo, desde el margen relevante bajo el paradigma de la acumulación hasta el margen relevante bajo el paradigma de la lesión, en el sentido del continuo que puede postularse desde la parte hasta el todo. Pero esa es una idea infundada.

La regulación medioambiental exige a la autoridad administrativa fijar una medida global de daño ambiental mediante las normas de calidad ambiental y una medida para las fuentes emisoras mediante las normas de emisión. La primera medida no tiene la función de constituir un estándar de daño susceptible de imputación a una sola fuente. Determinar la medida de gravedad del daño ambiental que se prohíbe penalmente en función de su aproximación al umbral de tolerabilidad fijado por una norma de calidad ambiental implicaría hacer de la infracción a esa prohibición un evento tan improbable que la regulación penal así definida sencillamente carecería de relevancia práctica. En lo que respecta a las normas de emisión, se trata por lo general de medidas fijadas bajo el paradigma de la acumulación. No hay razón para suponer que una emisión situada por encima del máximo permitido por las normas generales de emisión, por ejemplo, en un 50\%, un 100\% o un $200 \%$, sea por ese solo hecho considerablemente más significativa bajo el paradigma de la causalidad lesiva que la infracción del máximo permitido. Y la máxima satisfacción del imperativo legal conduce al mismo resultado absurdo desde el punto de vista de la regulación medioambiental: mientras más alto se fije el nivel de emisión prohibido por el derecho penal menor es la relevancia de la prohibición para la actividad de los agentes contaminantes.

Tampoco puede decirse que con esta técnica de regulación se eviten problemas sistémicos. El riesgo de elusión de control penal vía decisión administrativa se mantiene, pues, como se ha dicho, basta para ello con la fijación en el reglamento de niveles tan altos de emisión para la procedencia de la sanción que hagan impune la infracción económicamente significativa de las prohibiciones administrativas. Es cierto que la concentración de la intervención administrativa en un solo reglamento la hace más visible y en esa medida asegura mejor su control político, incluso por la opinión pública. Pero precisamente esa visibilidad acarrea un costo demasiado alto para la regulación administrativa medioambiental. El efecto de obligar al administrador a fijar nuevos niveles de emisión para que su infracción sea jurídicopenalmente relevante es la erosión de la autoridad de las normas generales de emisión.

Entre la medida de contaminación que es propia a las normas de calidad medioambiental y la medida de contaminación que es propia a las normas de emisión no hay lugar, pues, para un concepto de grave daño 
ambiental en el sentido de la causalidad lesiva. Imponer a la autoridad administrativa ambiental la fijación de un nivel de emisión constitutivo de grave daño en ese sentido es, por lo tanto, obligarla al ejercicio de la arbitrariedad.

Por cierto, lo dicho no implica una objeción insalvable en contra de la propuesta político-criminal de reservar la intervención del derecho penal, o, menos radicalmente, la aplicación de penas privativas de libertad, a casos particularmente graves de contaminación ambiental, dejando los casos menos graves a cargo de las sanciones administrativas o de penas menos severas que la privación de libertad. Semejante propuesta es plausible. El derecho comparado ofrece criterios vinculados al daño ambiental o a las condiciones de operatividad del sistema de gestión administrativa medioambiental para la configuración de casos graves, como los consagrados por el Art. 326 CP español ${ }^{57}$ y el § 330-(1) CP alemán ${ }^{58}$. Lo que carece de sentido, sin embargo, es pretender que en el contexto de una regulación administrativa de las emisiones contaminantes subordinada al paradigma de la acumulación ese rol diferenciador pueda ser cumplido por un concepto de daño ambiental definido conforme al paradigma de la causalidad lesiva. Esa pretensión representa una radical incomprensión de los presupuestos institucionales de la política-criminal relativa a la protección del medio ambiente.

\subsection{La calificación por la puesta en serio peligro de la vida o la salud de personas determinadas}

Tal como lo hace respecto de la hipótesis básica de producción de grave daño ambiental, el anteproyecto se remite al reglamento para la determinación complementaria del ámbito típico de la hipótesis calificada consis-

${ }^{57}$ El Art. 326 CP español agrava la pena aplicable al delito de contaminación ambiental cuando se da alguna de las siguientes circunstancias: (a) que la industria o actividad funcione clandestinamente, sin haber obtenido la preceptiva autorización o aprobación administrativa de sus instalaciones, (b) que se hayan desobedecido las órdenes expresas de la autoridad administrativa de corrección o suspensión de las actividades tipificadas en el artículo 325, (c) que se haya falseado u ocultado información sobre los aspectos ambientales de la misma, (d) que se haya obstaculizado la actividad inspectora de la administración, (e) que se haya producido un riesgo de deterioro irreversible o catastrófico y (d) que se produzca una extracción ilegal de aguas en período de restricciones.

${ }^{58}$ El § 330-(1) CP alemán establece la pena de privación de libertad de 6 meses a 10 años para los casos especialmente graves de comisión dolosa de los delitos contra el medio ambiente, considerando como ejemplos de casos especialmente graves: (a) cuando el perjuicio del agua, suelo o área especialmente protegida es irreversible o sólo se puede eliminar con un costo extraordinario o después de mucho tiempo, (b) cuando se pone en peligro el suministro público de agua, (c) cuando se daña permanentemente las existencias (de una especie) de animales o plantas amenazadas de extinción, (d) cuando se actúa con afán de lucro. 
tente en la puesta en serio peligro de la vida o la salud de personas determinadas (Art. 172 AP).

Esta decisión es inconsistente, pero no en virtud de la aplicabilidad a este caso del argumento desarrollado en la sección anterior. Incluso concediendo que ello sea factible para la autoridad administrativa ${ }^{59}$, es claro que en cumplimiento de este mandato de regulación complementaria dicha autoridad debe fijar una norma de emisión. Esa norma de emisión no puede, por definición, atender a la puesta en peligro de personas determinadas. El establecimiento necesariamente ex-ante de la norma de emisión hace imposible la constatación en ella de la causación de un resultado de peligro concreto.

Una regulación penal medioambiental consistente tiene que tomar aquí una decisión: o considera al peligro como concreto respecto de personas determinadas, y en ese caso no puede remitirse a una definición normativo-administrativa fijada ex-ante, o considera al peligro como común, y en ese caso puede efectuar esa remisión. Si toma esta última decisión, todavía puede hacer una diferenciación ulterior, admitiendo por ejemplo la relevancia del hecho de que en el caso concreto no hubiera persona alguna efectivamente expuesta a ese peligro, o que por las circunstancias del caso concreto esa emisión no pudo poner en peligro a persona alguna. Si admite que alguno de esos hechos excluye la punibilidad, configura a la calificación de peligro común en definitiva como un delito de peligro concreto, en el primer caso, o como un delito de peligrosidad, de peligro hipotético o de aptitud o idoneidad peligrosa, en el segundo; si no lo admite, la configura como calificación de peligro abstracto stricto sensu.

Lo que no puede hacer la norma penal medioambiental es lo que hace el anteproyecto: ordenar la fijación de una regla de peligro concreto a una autoridad administrativa que por sus presupuestos cognitivos se encuentra constreñida a fijar reglas de peligro abstracto.

\subsection{Las calificaciones por la producción de lesiones o muerte a una o más personas}

A diferencia de la calificación por la puesta en serio peligro de la vida o la salud de personas determinadas, la calificación por la producción de lesiones en una o más personas o de muerte a una o más personas tiene

\footnotetext{
${ }^{59}$ Esto depende de la cuestión puramente cognitiva de qué emisiones admiten la posibilidad de fijar un nivel en la fuente como peligroso para la salud de la población.
} 
un correlato entre los delitos contra las personas del anteproyecto ${ }^{60}$. Por tal razón, partiendo de la premisa de que en estas hipótesis el resultado de lesiones y/o muerte debe ser imputado al menos a título de imprudencia a la persona responsable del grave daño ambiental que lo produjo, las normas que establecen estas hipótesis calificadas tienen el carácter de reglas especiales sobre concursos de delitos.

La regla general sobre concursos de delitos del anteproyecto se encuentra en su Art. 53. Conforme a esa regla todo concurso de delitos debe tratarse conforme al principio de acumulación (determinación individualizada de penas, sumadas, con cumplimiento sucesivo partiendo por la más grave), pero con un límite superior (no más de dos grados a la correspondiente al delito más grave ni más de treinta años de reclusión en total).

El sistema de calificaciones de los Arts. 167 y 168 es inconsistente con una regla general de concursos basada en el principio de la acumulación, porque cada norma que configura una hipótesis calificada establece una pena única para los delitos en concurso en esa hipótesis. No se trata de una inconsistencia en un mero régimen de cálculo. En un sistema de determinación de la pena que se basa en la distinción entre determinación legal y determinación judicial, de modo que la primera constituye un marco dentro (o alrededor) del cual el tribunal debe determinar puntualmente la pena, el principio de acumulación exige determinación judicial de cada pena correspondiente por cada cargo, incluyendo la consideración de todas las circunstancias atenuantes y agravantes. Es, en lo esencial, una decisión legal de exclusión de cualquier alteración de los márgenes de apreciación del tribunal para la determinación judicial de la pena en razón de la pluralidad de cargos. ¿Por qué alterar esa decisión general en estos casos? ¿Cuál es la razón que explica esta anomalía?

En rigor, esta anomalía es doble. En tanto reglas concursales estas hipótesis calificadas no sólo son inconsistentes con la regla general sobre concurso de delitos (Art. 53 AP) sino también con la principal excepción a esa regla, la figura del homicidio calificado por su comisión con ocasión de la comisión de otro delito (Art. 83 AP) ${ }^{61}$ y la regla concursal para las lesio-

${ }^{60}$ La producción del resultado de muerte tiene su correlato en los delitos de homicidio doloso (Arts. 80, 81 y 82 AP) e imprudente (Art. 89 inciso primero AP). La producción del resultado de lesiones tiene su correlato en los delitos de lesiones corporales dolosas gravísimas (Art. $87 \mathrm{~N}^{\circ} 2 \mathrm{AP}$ ), simplemente graves (Art. $87 \mathrm{~N}^{\circ} 1$ AP) o menos graves (Art. 85 AP) e imprudentes (Art. 89 inciso segundo AP). La distinción del anteproyecto entre lesiones gravísimas, simplemente graves y menos graves corresponde a la actual regulación penal (Arts. 997 № 1, 397 № 2 y 399 CP, respectivamente).

61 “Art. 82. La misma pena del artículo anterior [15 años y 1 día a 20 años de reclusión, aplicable al homicidio calificado] se impondrá cuando el homicidio se perpetre con motivo u ocasión de la comisión de otro delito, antes o en el acto de cometerlo, para 
nes graves cometidas en las mismas circunstancias (Art. 88 AP) ${ }^{62}$. Esta excepción es, por supuesto, la gran inconsistencia del anteproyecto. ¿Cómo entender que la decisión radical de excluir todo régimen concursal alternativo a la acumulación de penas - exasperación, formación de pena únicasea reemplazada por el uso precisamente de esos regímenes excluidos en los casos simbólicamente más relevantes de concurso? Pero lo que aquí interesa es observar que esa excepción es efectuada por el anteproyecto exclusivamente para la comisión dolosa de homicidio o lesiones graves con ocasión de la comisión de otro delito, dejando entregado a la regla concursal general el tratamiento de la comisión imprudente de homicidio o lesiones graves en las mismas circunstancias ${ }^{63}$. Las calificantes de los Arts. 167 y

facilitar su ejecución, o después de cometido, para favorecer su impunidad. / Cuando el homicidio se cometa con motivo u ocasión de secuestro, sustracción de menores, torturas, robo o violación, se impondrá el máximum de la pena.” La estructura de este supuesto, reiterada en el Art. 88 AP para las lesiones, puede describirse como una errada inversión de la errada correlación que el Código Penal chileno hace entre el uso de medios coercitivos para la comisión de la acción de apropiación y la comisión de lesiones u homicidio en el contexto de esa acción. El error del Código consiste en considerar que todo caso de lesión y homicidio puede contar como ejecución violenta de máxima gravedad. El error del anteproyecto, en considerar que la extensión de las posibles situaciones de conexión entre la coacción y la apropiación, que justifica su consideración por igual como casos de robo, tienen sentido como conexiones entre el homicidio o lesiones y cualquier otro delito, para justificar la agravación de la pena de los primeros.

62 "Art. 88. A no ser que corresponda imponer mayor pena conforme a lo dispuesto en el artículo 53 de este Código, si las lesiones se perpetran con motivo u ocasión de la comisión de otro delito, antes o en el acto de cometerlo, para facilitar su ejecución, o después de cometido, para favorecer su impunidad, el responsable será castigado por todos los delitos cometidos: $/ 1^{\circ}$. Con el máximum de la pena señalada [10 años] si se trata de alguna de las lesiones comprendidas en el número $1^{\circ}$ del artículo anterior, / $2^{\circ}$ con la pena de reclusión mayor en su grado mínimo [5 años y 1 día a 10 años] si las lesiones fueran comprendidas en el número $2^{\circ}$, / $3^{\circ}$ Con la pena de reclusión mayor en su grado medio [10 años y 1 día a 15 años], tratándose de cualquiera de las lesiones señaladas en el artículo anterior, se perpetren con motivo u ocasión de la comisión de secuestro, sustracción de menores, torturas, robo o violación”.

${ }^{63}$ La decisión de agravar la pena del homicidio o de las lesiones cuando son cometidos “con ocasión” de la comisión de cualquier otro delito bien puede ser considerada como la expresión superlativa de una errada interpretación de la función que esa idea tiene en la legislación vigente. Si algún sentido tiene la hipótesis de calificación de un delito "con ocasión" de cuya comisión se comete además homicidio o lesiones, es la de recoger en ella la situación del homicidio o lesión imprudente o con dolo eventual que es la concreción de un peligro creado "con ocasión" de la comisión de un delito cuya comisión por regla general crea ese peligro, como el secuestro (Art. 141 inciso final CP), la sustracción de menores (Art. 142 inciso segundo CP), la violación (Art. 372 bis CP) o el robo con violencia o intimidación en las personas (Art. 433 CP) La aplicación que el anteproyecto hace de esta hipótesis sólo a la comisión dolosa —incluido el dolo directo- de homicidio y las lesiones, mas no a la comisión imprudente, y su apertura 
168 revierten tanto la regla general como la definición del ámbito de aplicación de la excepción a la misma, al aplicar una regla concursal de exasperación precisamente al caso de comisión imprudente de homicidio o lesiones con ocasión de la comisión del delito de grave daño al medio ambiente $^{64}$. ¿Qué razón puede justificar esta secuencia de inconsistencias sistemáticas?

Además de inconsistentes en sus premisas, estas calificantes lo son en sus resultados. Cabe advertir, eso sí, que las comparaciones en este ámbito no pueden ser seguras. Por sus consecuencias, es obvio que el principio de acumulación incrementa la incertidumbre acerca de la cuantía puntual definitiva de la pena en un caso de concurso de delitos. Esta incertidumbre impide hacer comparaciones concluyentes con los resultados de la aplicación de la regla de exasperación establecida por las calificantes. Con todo, un examen de coherencia al menos en el nivel de los marcos penales resultantes es indispensable. El anteproyecto no satisface ese examen.

La aplicación de la regla general de acumulación a los casos de concurso previstos por las hipótesis calificadas arrojaría resultados sensiblemente menos severos que las penas establecidas por las calificantes, tratán-

indiscriminada a la conexión puramente temporal con la comisión de cualquier otro delito, privan al intérprete del fundamento de imputación objetiva que sirve como principal criterio para una interpretación restrictiva de la hipótesis en cuestión. Esto es consecuencia de la extendida — y errada — idea en la doctrina nacional de que la imputación de la muerte o las lesiones al dolo del ladrón, secuestrador o violador representa el mejor y más importante criterio de interpretación restrictiva de las disposiciones del Código Penal (críticamente al respecto, Bascuñán Rodríguez, Antonio: "El Robo como Coacción”, 2002, p. 55 s., especialmente p. 86 s.). En el contexto del Código Penal chileno, que ocupa excepcionalmente esta hipótesis calificada, la tesis produce efectivamente consecuencias restrictivas de la penalidad; en el contexto del anteproyecto, en cambio, la misma tesis tiene un efecto exponencialmente expansivo de la penalidad.

${ }^{64}$ Asumo interpretativamente, que la comisión dolosa de homicidio o lesiones graves con ocasión de la comisión del delito de grave daño al medio ambiente queda entregada a la aplicación preferente de los Arts. 82 y 88 AP. De lo contrario, se incurriría en el absurdo de que el uso de la contaminación ambiental como medio comisivo de homicidio o lesiones graves acarrearía un privilegio penal para el autor. Cabe observar, en todo caso, que en el contexto de la regla concursal especial sobre el delito de lesiones el anteproyecto diferencia entre el tratamiento de las lesiones graves (Art. 87 AP) y el tratamiento de las lesiones menos graves (Art. 85 AP), aplicando el régimen especial a las primeras y con consecuencias similares o idénticas, y dejando las segundas entregadas a la regla general concursal. En el contexto de las calificantes del Art. 167 el anteproyecto sigue el criterio exactamente opuesto: incluye a las lesiones menos graves bajo un tratamiento idéntico al de las lesiones simplemente graves, y diferencia a éstas de las lesiones gravísimas. En el contexto de las calificantes del Art. 168, el anteproyecto difiere de ambos tratamientos: somete todas las tres clases de lesiones a un mismo régimen de penalidad. Otra anomalía más. 
dose de la muerte o las lesiones menos graves de una sola persona ${ }^{65}$. A la inversa, dependiendo del número de personas muertas o lesionadas, la aplicación de la regla general de acumulación podría llegar a establecer como única pena posible el máximo ${ }^{66}$, más del máximo ${ }^{67}$, el doble del máximo ${ }^{68} \mathrm{o}$ hasta el quíntuplo del máximo ${ }^{69}$ de las penas establecidas por las calificantes, que se aplican sin variación, cualquiera sea el número de víctimas.

Esta es una incoherencia francamente absurda en una regulación que pretende sancionar casos de grave daño al ambiente y que por lo mismo generan un peligro colectivo. Mientras más aislado o único es el daño causado a la salud o vida de las personas como concreción de ese peligro, más relevante resulta la aplicación de las reglas especiales de las calificantes frente a la regla concursal general. Mientras más masivo es ese daño, menos relevante es la aplicación de la regulación especial, llegando a ser

${ }^{65}$ Tratándose de las hipótesis del Art. 167, en el caso de la producción de muerte, la suma de penas conforme al Art. 53 AP podría ir de 3 años y 542 días a 8 años de reclusión, por comparación con la pena de 5 años y 1 día a 15 años de reclusión, establecida por el Art. 167 inciso final AP; en caso de producción de lesiones gravísimas, la suma de penas conforme al Art. 53 AP podría tener el mismo margen anterior, por comparación con la pena de 3 años y 1 día a 5 años, establecida por el Art. 167 inciso cuarto AP. En el caso de lesiones simplemente graves, la suma de penas conforme al Art. 53 AP podría ir de 601 días a 3 años 540 días de reclusión, por comparación con la pena de 3 años y 1 día a 5 años de reclusión, establecida por el Art. 167 inciso final AP. Tratándose de las hipótesis del Art. 168, en el caso de la producción de muerte, la suma de penas conforme al Art. 53 AP podría ir de 3 años y 62 días a 5 años de reclusión, por comparación con la pena de 3 años y 1 día a 10 años de reclusión, establecida por el Art. 168 inciso final AP; en caso de producción de lesiones gravísimas, la suma de penas conforme al Art. 53 AP podría tener el mismo margen anterior, por comparación con la pena de 541 días a 3 años, establecida por el Art. 168 inciso segundo AP. En el caso de lesiones simplemente graves, la suma de penas conforme al Art. 53 AP podría ir de 122 a 1080 días de reclusión, por comparación con la pena de 541 días a 3 años de reclusión, establecida por el Art. 168 inciso segundo AP.

${ }^{66}$ El límite de 15 años conforme al Art. 53 AP en relación con el Art. 89 inciso primero e inciso segundo AP, en los casos previstos por los incisos cuarto y final del Art. 167.

${ }^{67}$ El límite de 15 años conforme al Art. 53 AP en relación con el Art. 89 inciso primero e inciso segundo AP, en el caso previsto por el inciso final del Art. 168 AP; así como el límite de 5 años conforme al Art. 53 AP en relación con el Art. 89 inciso segundo AP, en el caso de la producción de lesiones simplemente graves previsto por el incisos tercero del Art. 168 AP.

${ }^{68}$ El límite de 10 años conforme al Art. 53 AP en relación con el Art. 89 inciso segundo AP, en el caso de lesiones simplemente graves previsto por el inciso cuarto del Art. 168 AP.

${ }^{69}$ El límite de 15 años conforme al Art. 53 AP en relación con el Art. 89 inciso segundo AP, en el caso de lesiones gravísimas previsto por el inciso segundo del Art. 168 AP. 
incluso contraproducente, al privilegiar al autor del delito de contaminación frente al que comete ese daño masivo usando otro medio de ataque.

La decisión del proyecto en orden a establecer la regla de acumulación como único régimen concursal de carácter general puede contar con razones en su favor. Particularmente, la vinculación de un régimen diferenciado - exasperación vs. acumulación — a la distinción entre unidad y pluralidad de acción, se ha demostrado siempre incierta, debido a las posibilidades de relativización de esa distinción. Con todo, si una propuesta legislativa adopta esa decisión, tiene que hacerse cargo de sus consecuencias de modo consistente.

Las reglas concursales especiales establecidas por el anteproyecto a propósito del homicidio y las lesiones demuestran que sus redactores no están dispuestos a abandonar el recurso al concurso ideal en caso de unidad medial de acción. Las reglas concursales especiales establecidas por el anteproyecto como calificantes de los delitos de contaminación demuestran que sus redactores no están dispuestos a abandonar el recurso al concurso ideal para situaciones preterinentencionales o de cadenas de sucesivas de causación de resultados.

Por último, la incoherencia constatada entre el resultado al que se llegaría aplicando la regla general concursal y el resultado al que se llega aplicando las calificantes de los delitos de contaminación demuestra que sus redactores no repararon en el caso que más concluyentemente requiere un tratamiento conforme al régimen de exasperación bajo la idea del concurso ideal, cual es, el delito masivo, caracterizado por la causación de resultados múltiples mediante una misma acción.

\section{La hipótesis de grave daño ambiental por infracción administrativa}

La configuración de una hipótesis de producción de grave daño ambiental con incumplimiento de las condiciones o exigencias fijadas por la administración con ocasión del otorgamiento de una autorización, certificación o permiso (Art. 169 AP) como tercer supuesto del grupo de los delitos de contaminación, paralelo a la comisión dolosa e imprudente, es sumamente problemática desde un punto de vista sistemático. La razón de ello radica en que el incumplimiento de las condiciones o exigencias fijadas por la autoridad administrativa no constituye una hipótesis alternativa a la comisión dolosa o imprudente, como sí lo son estas dos recíprocamente.

Dejando de lado su interpretación como lex specialis respecto de la normas de los Arts. 167 y $168^{70}$, y partiendo de la base que se encuentra

${ }^{70}$ Tal interpretación implicaría el absurdo de atenuar la penalidad aplicable a la comisión dolosa cuando además se incumple la regulación administrativa. 
asimismo excluida la posibilidad de apreciar un concurso de delitos entre el delito que ella tipifica y los delitos tipificados por los Arts. 167 y 168 ${ }^{71}$, puede concebirse a esta hipótesis de dos modos diversos.

En una interpretación posible, el Art. 169 configuraría un supuesto de imprudencia sin representación, estructurado restrictivamente por remisión a la infracción de normas administrativas particulares. Interpretada en este sentido, la hipótesis cumple la función de clarificar que no es la infracción a cualquier estándar de cuidado lo que permite fundar esa imputación, sino sólo la infracción a los deberes de cuidado provenientes de la regulación administrativa medioambiental.

Esta es con seguridad la concepción que tenía el proyecto de esta hipótesis $^{72}$. En el contexto del anteproyecto, sin embargo, la cuestión no es tan segura. Ello es así, porque el anteproyecto adopta tres decisiones en relación con esta figura que la diferencian de la regulación establecida en los Arts. 167 y 168 AP. Por una parte, excluye a su respecto el procedimiento administrativo de determinación del grave daño ambiental y el serio peligro para la vida o la salud de personas determinadas: el Art. 172 AP se remite a la regulación complementaria mediante reglamento sólo para los casos previstos en los Arts. 167 y 168 AP. Por otra parte, al desvincular la hipótesis del supuesto expreso de comisión imprudente del Art. 168, el delito tipificado en el Art. 169 debe interpretarse como un delito de comisión exclusivamente dolosa, por aplicación de la regla general del Art. $1^{\circ}$ AP. Finalmente, el anteproyecto establece la procedencia de la acumulación de sanciones administrativas y penales sólo respecto de este delito (Art. 169 in fine AP).

Si estas diferencias fueron establecidas de modo deliberado, entonces son sumamente significativas. Atendiendo a estas diferencias, el anteproyecto establecería un sistema doble de protección del medio ambiente. Por una parte, establecería un régimen de protección penal dependiente de la fijación de normas de emisión por un reglamento, pero en lo demás completamente independiente de la regulación administrativa y basado en la

${ }^{71}$ Dado que todas las disposiciones prevén los mismos resultados como elementos objetivos del tipo — grave daño ambiental, serio peligro para la vida o salud de personas determinadas, muerte o lesiones corporales de una o más personas - no hay manera de apreciar un concurso de delitos entre los delitos por ellas tipificados sin infringir la prohibición de ne bis in idem en sentido sustantivo.

${ }^{72} \mathrm{Su}$ Art. $2^{\circ}$ inciso primero tipificaba la hipótesis alternativa a la comisión dolosa mediante la fórmula "El (...) que por negligencia o incumplimiento de las disposiciones legales o reglamentarias causare un grave daño ambiental”. Atendiendo a su fundamentación es claro que esa fórmula distinguía entre “culpa por negligencia” y “culpa por infracción de reglamentos” como formas del delito culposo (imprudente) (Matus (ed.), op. cit. supra nota 2, p. 232). 
idea de la relevancia de la contribución contaminante desde el punto de vista del paradigma de la causalidad lesiva. Este sería el régimen establecido por los Arts. 167, 168 y 171 AP. Por otra parte, el anteproyecto establecería un régimen de protección penal relativamente dependiente de la regulación administrativa, subordinado no ya a ese reglamento especial y complementario de la regulación penal, sino accesorio a todo el régimen administrativo medioambiental. En este régimen de protección, la ilicitud jurídico-penalmente relevante se determinaría en parte bajo el paradigma de la acumulación (infracción administrativa) y en parte bajo el paradigma de la causalidad lesiva en la interpretación judicial de los conceptos indeterminados "grave daño ambiental” y "serio peligro para la vida o salud de personas determinadas”. Este sería el régimen establecido por el Art. 169.

Con esta decisión, el anteproyecto se habría distanciado del modelo regulativo propuesto por el proyecto, adoptando con carácter subsidiario un modelo de dependencia relativa referido a toda clase de normas administrativas, incluso las de carácter particular. Así, la emisión de elementos contaminantes por encima del nivel de emisión fijado por ese reglamento especial quedaría recogida por los Arts. 167 y 168 AP, que consagran el modelo propuesto por el proyecto. La emisión de elementos contaminantes por debajo de ese nivel de emisión quedaría recogida por el Art. 169 AP, que consagraría precisamente el modelo rechazado por el proyecto.

Dada la magnitud de las consecuencias vinculadas a una y otra interpretación, es obvio que el Art. 169 AP representa una disposición cuya ambivalencia es intolerable.

Si la finalidad del anteproyecto fue la de mantener la concepción del proyecto, entonces debió haber formulado la hipótesis de comisión imprudente mediante la fórmula alternativa del proyecto. Bajo esa finalidad, la consagración del Art. 169 constituye un error de técnica legislativa.

Si, por el contrario, la finalidad del anteproyecto consistió en establecer un régimen subsidiario de protección penal del medio ambiente divergente del modelo propuesto por el proyecto, entonces además de hacerlo de modo deficiente ${ }^{73}$, con ello refuta su principal planteamiento político-

${ }^{73}$ Aparte de la falta de claridad acerca de la radical diferencia de este supuesto respecto del régimen establecido por los Arts. 167 y 168, es un error aplicar las penas del delito imprudente (Art. 168) a las calificaciones por producción de peligro para la vida o la salud de personas determinadas, o de muerte o lesiones corporales de una o más personas. Las posibles diferencias en la magnitud del daño ambiental podrán justificar la diferencia de penas en relación con el inciso primero del Art. 167, pero en ningún caso pueden justificar que reciba un tratamiento privilegiado — como si fuera autor de delito imprudente - el que dolosamente genera un peligro que se concreta ulteriormente en la muerte o lesiones de una persona. Desde el punto de vista de estas calificantes, el disvalor es idéntico en los Arts. 167 y 169, si éste es también un delito de comisión dolosa. 
criminal: si es razonable sancionar con pena privativa de libertad los atentados ambientales bajo su consideración como infracciones administrativas que producen un grave daño — dejando al intérprete la determinación de éste-, entonces todas las decisiones que caracterizan la regulación de los Arts. 167 y 168 están de más.

\section{El delito de incumplimiento del sistema de evaluación de impacto ambiental}

El Art. 170 AP sanciona con una pena de multa la ejecución de proyectos o actividades que deben someterse al sistema de evaluación de impacto ambiental sin hacerlo, o su ejecución en términos diversos a los que fueron aprobados o autorizados. Esta pena de multa es acumulativa a las penas aplicables por la comisión de atentados al medio ambiente, previstos en los Arts. 167, 168 y 169. La disposición proviene del proyecto (Arts. $4^{\circ}$ y $5^{\circ} \mathrm{P}$ ).

La previsión de esta disposición en el contexto del proyecto y el anteproyecto resulta desconcertante por varias razones.

En primer lugar, la admisión de una norma que configura un delito medioambiental con la estructura típica de un delito de peligro abstracto stricto sensu, cuyo injusto sólo puede ser determinado por remisión a normas administrativas particulares, constituye una negación rotunda de las premisas bajo las cuales son configurados los demás delitos de atentado al medio ambiente. Si las emisiones de sustancias o elementos contaminantes no son legítimamente punibles a menos que causen un efecto más significativo que el prohibido por las normas generales de emisión y que se encuentre así definido por un reglamento especial, ¿cómo pueden ser consideradas legítimamente punibles las infracciones a deberes administrativos, incluso particulares, sin que produzcan el menor daño o puesta en peligro del medio ambiente?

La observación del proyecto, en el sentido de que esta estructura es la que corresponde a delitos contra bienes jurídicos institucionales ${ }^{74}$ es enteramente correcta, pero no contribuye en nada a superar la grave incongruencia aludida. Ello, porque la razón de la incriminación de estos comportamientos no obedece a la finalidad de asegurar la producción de un bien institucional, sino a la de anticipar la protección del medio ambiente a un estadio previo a su lesión o puesta en peligro ${ }^{75}$. Si se admite la legitimidad

${ }^{74}$ Matus (ed.), op. cit. supra nota 2, p. 231.

${ }^{75}$ Distinto es el caso de otras normas del proyecto, que sancionaban falsedades cometidas con ocasión del cumplimiento de deberes de información al sistema de evaluación de impacto medioambiental (Art. $7^{\circ}$ CP; para su fundamentación, pp. 214-216 [op. cit.]). Esas disposiciones no fueron adoptadas por el anteproyecto. 
de una estructura de peligro abstracto y referida a actos administrativos particulares para brindar esa protección anticipada, no puede considerársela inaceptable para tipificar atentados directos contra el bien jurídico.

Ciertamente, entre la pena prevista por el anteproyecto para este delito y las penas previstas para los delitos de contaminación existe una importante diferencia en su naturaleza, que es exclusivamente patrimonial en el caso de este delito. Pero precisamente eso demuestra que para los propios redactores del proyecto y el anteproyecto no es concluyente la objeción de principio en contra del uso de esta técnica de tipificación de los delitos contra el medio ambiente. El Art. 170 demuestra que para el proyecto y el anteproyecto ni los argumentos basados en el principio de legalidad, ni los argumentos basados en el principio de exclusiva protección de bienes jurídicos justifican la pretendida ilegitimidad de la configuración de estas estructuras típicas por las normas penales medioambientales. La única cuestión que permanece como relevante al respecto es la satisfacción del principio de proporcionalidad mediante una razonable determinación legal de la pena.

Precisamente desde este punto de vista es que resulta desconcertante, en segundo lugar, la disposición en cuestión. El principio de proporcionalidad establece como exigencia general la necesidad racional de la actuación estatal que afecta derechos fundamentales —en este caso, una norma punitiva que establece una pena patrimonial - como medio para la obtención del fin perseguido. Pero si algo es dudoso en todo el amplio espectro de cuestiones que plantea la protección penal del medio ambiente es precisamente que el sistema de evaluación de impacto ambiental requiera un reforzamiento punitivo para su efectividad. Los redactores del proyecto manifiestan su sorpresa ante la inexistencia de una norma que sancione la omisión de incorporación al procedimiento de evaluación de impacto ambiental $^{76}$. El hecho no es, sin embargo, sorprendente. Precisamente la necesidad instrumental de contar con los permisos y certificaciones administrativas para poder realizar una actividad o ejecutar un proyecto de los sometidos al sistema debería bastar para asegurar su efectividad. Y si alguna necesidad existiera de reforzamiento sancionatorio, debería quedar a cargo del derecho administrativo sancionador. Desde luego que es posible identificar algunos casos en que por su especial peligrosidad para el medio ambiente parece necesario un reforzamiento penal de la imperatividad del sistema administrativo de control preventivo. El supuesto del Art. 171 AP, que se comenta en la sección siguiente, en la medida que se cometa en el

${ }^{76}$ Op. cit., pp. 214-216. 
contexto de un proyecto o actividad sometido al sistema de declaración de impacto ambiental, constituye un caso preciso de especial peligrosidad. El ejemplo del derecho comparado en ese sentido se encuentra en el § 327-(2) CP alemán, que sanciona con pena privativa de libertad de hasta tres años o la respectiva multa el manejo no autorizado de plantas de emisión aérea cuyo manejo fue prohibido por razones de seguridad, de instalaciones de tuberías conductoras de contaminantes hidráulicos o de plantas de eliminación de desechos. Pero un reforzamiento penal indiscriminado del procedimiento administrativo de control de riesgos ambientales se encuentra totalmente fuera de lugar bajo el principio de proporcionalidad.

En tercer término, la previsión de esta norma es desconcertante porque su aplicación efectiva contradiría otra de las razones esgrimidas por los redactores del proyecto para abstenerse de tipificar atentados contra el medio ambiente con una estructura típica semejante a la de este delito. El proyecto atribuye importancia — con razón— al fenómeno de la persecución de casos de bagatela como un hecho que erosiona la legitimidad del derecho penal medioambiental ${ }^{77}$. Como se ha visto, la manera con que el proyecto pretende evitar este fenómeno es restringiendo la punibilidad de los actos contaminantes a emisiones que sobrepasen un nivel fijado por un reglamento especial y por encima del nivel prohibido por las reglas generales de emisión. Desde luego, esa restricción no garantiza que el ministerio público persiga efectivamente los casos de grave contaminación que lleguen a ocurrir. Además, tal como se dijo antes, un posible efecto de una decisión tan drásticamente restrictiva es terminar haciendo de la regulación penal un estándar irrelevante para la práctica de los agentes contaminantes. A esas consideraciones se agrega ahora la contradicción representada por la norma consagrada en el Art. 170. Conforme a esta regulación, en vez de orientar al ministerio público hacia la investigación y acusación de los responsables por las emisiones contaminantes que contravengan la regulación administrativa, se lo constriñe a preocuparse de infracciones administrativas irrelevantes como acciones de contaminación.

Finalmente, esta disposición resulta desconcertante por el carácter auténticamente concursal con los delitos de contaminación que el proyecto y el anteproyecto le asignan. La idea de que el cargo y la pena por un delito de peligro abstracto se acumulen al cargo y la pena por el delito de peligro concreto o de lesión del mismo bien jurídico resulta problemática — cuando no derechamente inadmisible- bajo el principio de proporcionalidad, en su concreción como prohibición de exceso por doble valoración (ne bis in idem sustantivo). Conforme a este principio, las normas punitivas referidas

\footnotetext{
${ }^{77}$ Ibídem, pp. 122-123.
} 
a los estadios sucesivos y más graves de afectación del bien jurídico deben entenderse como consuntivas de las normas punitivas referidas a los estadios previos y menos graves de afectación. La correcta relación sistemática entre las normas que sancionan los atentados de contaminación y esta norma se encuentra, por lo tanto, en la atribución a ésta de un carácter estrictamente subsidiario.

La única manera en que una defensa del anteproyecto podría hacer frente a estas objeciones sería sosteniendo que la norma del Art. 170 protege un bien jurídico institucional, distinto del medio ambiente. Algo así como el adecuado orden de la función administrativa de gestión medioambiental. Eso significaría, sin embargo, hacer de la mera obediencia a la administración la finalidad de protección de la norma penal.

\section{El manejo ilícito de sustancias tóxicas o peligrosas}

El Art. 171 sanciona las acciones de extraer, producir, transformar, transportar, distribuir, vender, comprar, importar, guardar o almacenar, sin la competente autorización o incumpliendo condiciones u obligaciones, sustancias tóxicas o peligrosas en cantidades tales que constituyan un serio peligro de grave daño ambiental. La pena se agrava si ese peligro incluye un serio riesgo para la vida o la salud de personas determinadas. Ambos peligros deben ser determinados por el reglamento especial que determina el grave daño ambiental en el sentido de los Arts. 167 y 168 AP, conforme lo dispone el Art. 172 inciso tercero AP.

Desde luego, la crítica efectuada antes a la remisión al reglamento para determinar cuándo se crea un serio peligro para la vida o salud de personas determinadas (sección 5.3) es enteramente aplicable a la norma que tipifica la hipótesis calificada de este delito: la fijación ex-ante por una norma de un peligro concreto es imposible.

Distinto es el caso de la fijación por reglamento de las sustancias tóxicas o peligrosas que constituyan a partir de una determinada cantidad un serio peligro de grave daño para el medio ambiente. Esa sí es una estimación que la autoridad administrativa puede efectuar y fijar ex-ante. Eso no hace, por supuesto, a este delito uno de peligro concreto. Se trata de sustancias peligrosas de manejo permitido bajo condiciones administrativas. Mientras su manejo cuente con la autorización administrativa y satisfaga en lo demás las condiciones y exigencias administrativas, el peligro corresponde a un riesgo permitido. Si, por el contrario, el manejo no cuenta con la autorización administrativa, incumple condiciones o infringe exigencias, en- 
tonces se realiza el tipo, aunque de hecho ese manejo no haya producido resultado alguno de incremento del peligro inherente al riesgo permitido. Es un delito de peligro abstracto.

La misma razón demuestra que la función que desempeña en este delito la norma reglamentaria que determina las sustancias y sus cantidades no es la misma que la que desempeña la norma que determina el grave daño ambiental de los Arts. 167 y 168. Esa determinación fija el resultado cuya producción se encuentra prohibida por la norma de comportamiento establecida en dichos artículos. Acá, por el contrario, la prohibición establecida por el Art. 171 requiere un complemento adicional, dado por la regulación administrativa general y particular. Tal como el 170, este es un caso de dependencia del derecho penal respecto de actos administrativos particulares. En otras palabras, una demostración más de la procedencia de una técnica regulativa que el proyecto y el anteproyecto rechazan para la configuración de los delitos de contaminación.

La asimetría entre la rigidez con que se pretende tratar a los delitos de contaminación y la flexibilidad con que se trata esta situación no puede dejar de producir absurdos. El Art. 170 no contempla la hipótesis de "verter” o “desechar” estas sustancias. El vertido o desecho con infracción administrativa no es punible, a pesar de que constituyen las acciones que con mayor probabilidad producen un resultado de incremento de peligrosidad para el medio ambiente, si no derechamente el resultado de daño que se busca evitar. Por cierto, esas acciones pueden contar como daño, en el sentido de los Arts. 167 y 168, pero su punibilidad bajo esos artículos requiere que el hecho sea calificado por el reglamento como "grave daño ambiental”, lo cual a su vez exige que ese vertido o desecho constituya una emisión en el sentido de las normas de emisión y que su cantidad "supere significativamente” el máximo permitido por las normas generales.

El daño medioambiental derivado del manejo de desechos, cuya evitación constituye una prioridad del sistema administrativo medioambiental y que atendiendo a la información disponible se encontraría particularmente necesitado de reforzamiento coercitivo ${ }^{78}$, no tiene un tratamiento adecuado en el anteproyecto ${ }^{79}$.

${ }^{78}$ Según un estudio empírico del período 1994-2007 en la región del Bío-Bío, el número más significativo de visitas de fiscalización y de constatación de incumplimiento parcial se concentra en proyectos de saneamiento ambiental: Lamas, Jaime y Carlos Chávez, "El Sistema de Evaluación de Impacto Ambiental. Análisis del Diseño de Fiscalización y su Cumplimiento en la Región del Bío-Bío”, 2007, p. 205 s.

${ }^{79}$ Como ejemplo en el derecho comparado de regulación penal de los delitos cometidos con ocasión del desarrollo de actividades relacionadas con el manejo de basura peligrosa cabe mencionar el § 326 CP alemán. En su primer apartado, esta disposición 


\title{
9. La determinación del ámbito de autoría
}

Todas las disposiciones sobre delitos relativos al medio ambiente contenidas en el anteproyecto (Arts. 167, 168, 169, 170 y 171 AP) tipifican el delito usando la siguiente fórmula para caracterizar al autor: "El responsable o administrador de un proyecto o actividad" ${ }^{\text {. }}$. La justificación de esta manera de determinar el ámbito de autoría se encuentra en el siguiente pasaje de la fundamentación del proyecto:

\begin{abstract}
...consciente de que la mayor parte de los delitos ambientales contemplados en él se cometen en el ámbito de una organización empresarial (...) [el proyecto] pone en primera línea de imputación a los gerentes, directores y administradores a cualquier título del proyecto o actividad donde se origina la fuente de emisión de contaminantes... ${ }^{81}$.
\end{abstract}

Difícilmente pueda encontrarse un caso más elocuente de identificación correcta de un problema y deficiente propuesta de solución.

El punto de partida del proyecto es enteramente correcto: los delitos medioambientales más relevantes se cometen en el ámbito de organizaciones de personas que persiguen fines económicos, ya sean empresas particulares o agencias productivas estatales. El diagnóstico es también enteramente correcto: tratándose de delitos cometidos en el marco de organizaciones de personas el objetivo relevante de la persecución penal es alcanzar a los individuos que detentan posiciones de control de la organización. Lograr ese objetivo es sin embargo una cuestión difícil, debido al hecho de que quienes detentan posiciones de control por regla general no intervienen en su realización de una manera coincidente con la descripción que de ella se hace en el tipo configurado por la norma punitiva ni se relacionan con la realización de la acción típica como “hombre-de-atrás” del modo relativamente simple presupuesto paradigmáticamente por las reglas

\footnotetext{
sanciona con pena privativa de libertad de hasta cinco años o multa respectiva el tratamiento, almacenamiento, depósito, evacuación o eliminación de desechos que sean peligrosos por su carácter patógeno, explosivo o inflamable, o gravemente contaminantes. El contenido normativo del Art. 171 AP corresponde en el contexto del CP alemán a su $\S 328$.

${ }^{80}$ En el Art. 171 AP los términos de la fórmula aparecen invertidos: "El administrador o responsable de un proyecto o actividad". La variación no parece tener mayor trascendencia. Esta fórmula es una adaptación de la expresión utilizada por el proyecto para tipificar los dos principales delitos de daño medioambiental: "El responsable de una fuente emisora" (Arts. $1^{\circ}$ y $2^{\circ} \mathrm{P}$ )

${ }^{81}$ Matus (ed.), op. cit. supra, nota 2, p. 232.
} 
generales sobre autoría mediata y coautoría. Por tal razón, es imprescindible contar con estructuras normativas de imputación de autoría para afirmar su responsabilidad penal ${ }^{82}$.

La propuesta de regulación del proyecto y el anteproyecto no constituye, sin embargo, una solución al problema en cuestión. Por el contrario, lo único que ella logra es generar problemas aun más graves que el que pretende solucionar. La razón de ello es fácil de identificar. Al introducir la regla de imputación en la descripción típica de la acción se la transforma en una regla de comportamiento. Esto acarrea las siguientes consecuencias problemáticas.

En primer término, medida por sus efectos como norma de comportamiento esta fórmula implica una decisión de política legislativa mucho más radical que "poner en primera línea de imputación” al controlador de una empresa por los daños ambientales causados en el contexto de su operación. La fórmula utilizada por el anteproyecto hace que el tipo legal exija como presupuesto necesario de la punibilidad que la acción contaminante sea realizada en el contexto de la “operación” de "un proyecto o actividad”. Esto implica declarar penalmente irrelevante cualquier otro caso de producción de daño ambiental, cualquiera sea su gravedad.

Una consecuencia tan radical no sólo requiere tematización y justificación explícita —ausente en el proyecto—, sino además que su expresión institucional sea satisfactoria. La fórmula “operación de un proyecto o actividad” proviene de la regulación medioambiental (Arts. 10 y 11 Ley 19300), en cuyo contexto no desempeña función delimitadora o selectiva alguna; por el contrario, se trata de términos usados en el sentido más general posible para servir de común denominador a las hipótesis establecidas en esas disposiciones, que se refieren a clases de actividades o a obras, o a una combinación de ambas. Su apropiación por la regulación penal como términos que designan condiciones de aplicabilidad de una regla de imputación puede ser considerada como satisfactoria. En tanto términos que cumplen la función de criterio de delimitación del modo de ataque típico, por el contrario, la fórmula claramente no lo es. Ello, porque obviamente la pregunta de cómo imputamos responsabilidad por una acción típica tolera más

82 Para un vistazo al respecto, Schünemann, Bernd: Temas Actuales y Permanentes del Derecho Penal... (op. cit., supra, nota 3), capítulo "Los fundamentos de la responsabilidad penal de los órganos de las empresas". En su primer apartado, esta disposición sanciona con pena privativa de libertad de hasta cinco años o multa respectiva el tratamiento, almacenamiento, depósito, evacuación o eliminación de desechos que sean peligrosos por su carácter patógeno, explosivo o inflamable, o gravemente contaminantes. El contenido normativo del Art. 171 AP corresponde en el contexto del CP alemán a su §328. White, Peter C.: "Environmental Justice Sence Hammurabi: From Assigning Risk 'Eye-for-Eye' to Modern Day Application of the Responsable Corporate Officer Doctrine", 2005, p. 633. 
imprecisión que la pregunta de cuál es la acción típica. En tanto elemento del tipo, su vaguedad entra en tensión con el principio de legalidad ${ }^{83}$.

En segundo lugar, cabe señalar que al interior del ámbito de las organizaciones de personas el único efecto inmediato que se logra con esta fórmula es configurar estos delitos como delitos especiales, es decir, restringir el círculo de autoría a personas que detentan ciertas calidades personales. Semejante tipificación hace en principio atípica la intervención en la comisión del hecho por parte de quienes no poseen esas calidades. En otras palabras, con esta manera de “poner en primera línea” a ciertas personas, lo que se logra en rigor es excluir en principio de esa línea a las demás. Este efecto absurdo es compensado de modo parcial por una regla del anteproyecto que extiende la responsabilidad por autoría a las acciones de "sabotaje” o la "intervención de terceros de similares características” (Art. 228 inciso final AP). La regla supone una contravención al interior de la organización de las medidas de cuidado dispuestas por el responsable o administrador del proyecto. De modo que si éste es un autor mediato o coautor doloso, la punibilidad de quien ejecuta de propia mano la acción causante del grave daño medioambiental no queda cubierta por estas normas, sino que depende de que alguna regla de la parte general la afirme extensivamente ${ }^{84}$.

${ }^{83}$ Por supuesto, la manera convencional de resolver este problema sería acudiendo al catálogo de hipótesis de los Arts. 10 y 11 de la Ley 19300 como complemento regulativo. Pero esto implicaría restringir aún más el ámbito típico de los delitos de contaminación, reduciéndolos a atentados cometidos en el marco de los proyectos o actividades sometidos al sistema de evaluación ambiental. Ni siquiera en el contexto del proyecto, más directamente dependiente de la regulación medioambiental en su carácter de ley especial, esto parece haber respondido a la representación de sus redactores. Como se vio en la sección 5.2, la protección directa del medio ambiente se sujeta en el proyecto a la consideración de la gravedad del daño como criterio selectivo de merecimiento de pena; la consideración del sistema de evaluación de impacto ambiental sólo es relevante para la definición del ámbito típico de los delitos con cuya punición se pretende dispensar protección indirecta al medio ambiente (sección 7). Esta disyunción aparece claramente manifestada en el pasaje de la fundamentación del proyecto transcrito arriba, que en su texto original se refiere a los proyectos o actividades "donde se origina la fuente de emisión de contaminantes $o$ que están obligados a someterse al Sistema de Evaluación de Impacto Ambiental" (loc. cit. supra, nota 62).

${ }^{84}$ En el contexto del anteproyecto, esa regla podría encontrarse en su Art. 45 AP, siempre que se entienda a la calidad especial del autor en estos delitos como una “disposición moral del sujeto" u otra "causa personal”, en el sentido de ese precepto y que se entienda a los demás interventores —incluso al autor directo o de propia manocomo "partícipes" en el sentido de esa misma disposición. En tal caso, estos últimos no quedarían exentos de responsabilidad, sino que su pena recibiría una atenuación. Cabe observar que si esta es regla extensiva supone necesariamente intervención del autor especial, entonces el tercero que intervenga con independencia del responsable o administrador del proyecto o actividad y sin que su acción tenga lugar concurriendo las circunstancias del Art. 228, no sería penalmente responsable. 
En lo que respecta ahora al propósito de facilitar la imputación de responsabilidad penal al autor especial, cabe observar, además, que según como se interprete la fórmula en cuestión ella o bien en nada facilita la consecución de ese propósito o bien lo hace mediante una presunción que entra en conflicto con la prohibición constitucional de presumir de derecho la responsabilidad penal.

La fórmula empleada por el anteproyecto puede ser interpretada de dos modos. Una interpretación posible consiste en entender que la imputación de responsabilidad en calidad de autor al responsable o administrador de un proyecto o actividad exige, además de la comprobación de esa calidad, la comprobación de la intervención ejecutiva de esa persona en la acción de "producir un grave daño ambiental en la operación del proyecto o actividad” (Art. 167 para la producción intencional, Art. 168 para la producción negligente, Art. 168 para la producción con infracción de condiciones o exigencias administrativas) o en las distintas acciones relacionadas con el tráfico de sustancias tóxicas (Art. 171). Así interpretada la fórmula, ella no produce avance alguno: hay que probar una conexión entre ese autor especial y la ejecución de la acción. Más bien, la fórmula dificulta la imputación de responsabilidad, en la medida en que sustituye las estructuras generales de imputación de autoría mediata y coautoría (Art. 10 AP), que no requieren intervención ejecutiva directa, por una estructura especial que sí pareciera requerir esa clase de intervención.

La otra interpretación posible consiste en entender que la regla imputa responsabilidad penal en calidad de autor al responsable o administrador de un proyecto o actividad con tal que en el contexto de ese proyecto o actividad se produzca - por quien sea - un grave daño ambiental (Arts. $167,168,169)$, o sean realizadas — por quien sea— las acciones relacionadas con el tráfico de sustancias tóxicas (Art. 171). Bastaría con el acaecimiento de un resultado de grave daño medioambiental fuera causalmente reconducible a una acción intencional (Art. 167), negligente (Art. 168) o con infracción de normas administrativas (Art. 169), realizada por cualquier persona en el contexto operativo de ese proyecto o actividad para justificar la imputación de responsabilidad en calidad de autor doloso, negligente o con infracción de reglamento a la persona que detenta esa posición en la organización. Una regla de esta naturaleza prescinde de cualquier estructura normativa de imputación de autoría que identifique los hechos propios cuya prueba es necesaria para atribuir responsabilidad penal por un hecho ajeno. Así interpretada, la fórmula no "pone en primera línea de imputación” a esas personas, sino que derechamente presume su responsabilidad penal. 
Se trata, por lo tanto, de una fórmula cuyo sentido es distinto al de una regla de imputación. Las estructuras normativas de imputación de autoría cumplen obviamente una función heurística para la producción de la prueba de los hechos fundantes de la responsabilidad penal de quienes detentan posiciones de control en el marco de organizaciones de personas. Pero por sí mismas no relevan de la carga de la prueba al ministerio público. La regla del anteproyecto, en cambio, autoriza directamente la imputación de responsabilidad por hecho de tercero, con tal de probarse la condición de responsable o administrador del proyecto o actividad ${ }^{85}$.

A pesar de diferir tanto de su pretendida finalidad, la comprensión de esta fórmula como una presunción es la interpretación que mejor concuerda con la representación del proyecto y el anteproyecto. Así lo demuestra la existencia de una regla de exención de responsabilidad para los responsables o administradores de proyectos o actividades por la acreditación de acciones de oposición a la realización del comportamiento delictivo o la adopción previa de medidas de control cuya infracción originó el resultado de grave daño ambiental (Art. 13 P, Art. 228 AP). Esta regla, además, tendría la virtud de hacer de la presunción en cuestión una regla legal de inferencia probatoria refutable, es decir, una presunción simplemente legal. Con ello se salvaría su posible inconstitucionalidad por infracción a la prohibición de presunción de derecho de la responsabilidad penal establecida en el Art. 19 Nº 6 de la Constitución.

Pero las cosas no son tan simples.

Si el proyecto y el anteproyecto hubieran descansado en alguna estructura normativa de imputación de autoría, y hubieran establecido en forma explícita una presunción simplemente legal en contra de quienes detentan posiciones de control en el ámbito de las organizaciones de personas, la inferencia contenida en esa presunción sería efectivamente compatible con la Constitución. Ello es así, porque semejante presunción no afectaría la posibilidad de refutar la inferencia que ella ordena mediante prueba del acusado relativa a la falta de concurrencia de los hechos correlativos a los presupuestos fácticos de esas estructuras normativas de imputación.

Es cierto que el anteproyecto — no así el proyecto- admite para estas personas prueba de exención de responsabilidad conforme "a las re-

${ }^{85}$ La diferencia entre el sentido de una y otra regla marca las dos interpretaciones contrapuestas de las disposiciones estatutarias norteamericanas que han recogido la doctrina del oficial corporativo responsable, esto es, su concepción como una regla de responsabilidad estricta o su concepción como una regla de omisión de deberes de evitación (White, op. cit., supra nota 82, p. 646 s.). 
glas generales” (Art. 228 inciso segundo AP). El problema radica, sin embargo, en que, por estar formulada la presunción como una regla especial de autoría ella excluye la aplicación a estos supuestos de las reglas generales de autoría del anteproyecto (Art. 10 AP). Luego, esa referencia del Art. 228 inciso segundo AP a "las reglas generales" sólo puede entenderse como referida a la posibilidad probar la concurrencia de circunstancias eximentes de responsabilidad penal (Art. $6^{\circ}$ AP), como causas de justificación o de exculpación, pero no a la negación de la condición de autor.

Esto es consistente con la intención del proyecto, en orden a restringir la excepción de responsabilidad a directivos...

...cuando es posible demostrar su oposición a los hechos constitutivos de delito, acciones de sabotaje u otra intervención de tercero imposible de controlar por los mecanismos internos de la empresa ${ }^{86}$.

Pero la exclusión legal de posibilidades objetivamente pertinentes de refutación de una presunción establecida por la ley hace de esa presunción, en el margen de las posibles refutaciones excluidas, una presunción de derecho. La fórmula del proyecto y el anteproyecto resulta, por lo tanto, inconstitucional.

Para enfrentar el problema que el proyecto pretendía resolver es preciso, primero, entender que los delitos de contaminación no son necesariamente “delitos de organización”. Cuando el tipo presupone la realización de actividades complejas que tienen lugar en el marco de una organización de personas, entonces se justifica la consideración directa de quien tiene el dominio efectivo de la organización como autor. Lo más cercano a un delito de esta clase en el contexto del anteproyecto es el supuesto de hecho del delito de ejecución de un proyecto o actividad con omisión de incorporación al sistema de evaluación de impacto ambiental (Art. 170). Pero ese no es necesariamente el caso de los atentados contaminantes. Un delito de daño al medio ambiente no requiere definición como delito de organización.

Además, es importante advertir que los problemas de imputación de responsabilidad a quienes detentan posiciones de control en el marco de una organización de personas deben tratarse a partir de las reglas generales relativas a la comisión por omisión (deberes de garante de los detentadores de posiciones de control) y al actuar en lugar de otro (autoría del detentador de posición de control en casos de delitos de organización). No contemplar reglas sobre estas materias en su parte general es un grave defecto del anteproyecto. El costo de ese defecto se hace aquí efectivo: la falta de

${ }^{86}$ Matus (ed.), loc. cit. supra, nota 81. 
claridad sobre el objeto de la regulación conduce al anteproyecto a tipificar delitos especiales y establecer presunciones allí donde lo que se requiere son reglas de imputación ${ }^{87}$.

\section{La autorización administrativa}

A propósito del comentario de los Arts. 169 y 170 se pudo apreciar lo anómala que resulta la tematización de la ilicitud por falta de autorización o por incumplimiento de condiciones o exigencias administrativas en estas disposiciones, y no en los Arts. 167 y 168. Esa anomalía se debe a una decisión deliberada del proyecto.

Como se dijo arriba, la regulación penal medioambiental tiene que aceptar su dependencia, al menos relativa, de la regulación administrativa medioambiental. El término con que se designa este fenómeno en la doctrina penal alemana y española es el de "accesoriedad administrativa”, distinguiéndose tres modos de accesoriedad: la accesoriedad conceptual, es decir, el uso por las disposiciones penales de conceptos y categorías definidos por la regulación administrativa, la accesoriedad de derecho, es decir, la remisión por las normas penales a las normas generales de la regulación administrativa (legislación, reglamentos), y la accesoriedad de acto, es decir, la remisión por las normas penales a las normas particulares o actos jurídicos administrativos (resoluciones que conceden o deniegan permisos o establecen condiciones o exigencias específica $)^{88}$. El proyecto aborrece la accesoriedad de acto. Considera que la dependencia de la ilicitud penal de la decisión de un órgano administrativo erosiona la legitimidad del derecho penal ante el ciudadano medio, porque disocia la relevancia jurídico penal de la conducta de su dañosidad medioambiental. La sanción penal de actos contaminantes que no sean particularmente graves en el sentido de la causalidad lesiva y la impunidad vía autorización administrativa de actos contaminantes mucho más significativos en el sentido de la causalidad lesiva

${ }^{87}$ Aparte de la formulación legal de estructuras de imputación de responsabilidad por el delito cometido al interior de la organización, cabe mencionar la estrategia regulativa consistente en tipificar un delito especial de lesión de deberes de vigilancia, como el supuesto establecido en el § 130 de la Ordenanza sobre Contravenciones Administrativas alemana (al respecto, Otto, “Das neue...”, op. cit., supra nota 3, p. 138). En la discusión legislativa que originó la reforma de 1994 al Código Penal alemán se propuso introducir una norma de estas características como nuevo § 261 del Código Penal, sin que la propuesta se impusiera en definitiva (al respecto, Steindorf, op. cit., nota 3, p. 30).

${ }^{88}$ Para un vistazo general, De la Mata Barranco, op. cit., supra nota 35, loc. cit., especialmente p. $78 \mathrm{~s}$. 
constituiría en la representación del ciudadano medio una contradicción valorativa insalvable que desacreditaría la práctica punitiva estatal ${ }^{89}$.

Ya se ha constatado la inconsistencia con que el proyecto y -aun más intensamente- el anteproyecto se hacen eco de esa preocupación. Mientras que la definición de los delitos más graves de contaminación se caracteriza por evitar la accesoriedad de acto, la definición de los demás delitos —incluyendo la hipótesis de daño ambiental del Art. 169 en su interpretación como delito doloso- se entrega por completo a esa técnica de dependencia administrativa. Esta inconsistencia plantea la interrogante acerca del sentido que pueda tener una disparidad tan radical en la definición de la estructura de los tipos delictivos. Pues a estas alturas resulta bastante obvio que un ciudadano que espera del derecho penal del medio ambiente la misma evidencia intuitiva de las normas y la misma conmensurabilidad de las intervenciones que demuestra el derecho penal, por ejemplo, a propósito de las lesiones corporales, es un ciudadano que no entiende en qué consiste la protección penal del medio ambiente. No es el derecho penal el que necesita adecuarse a los estándares de ese ciudadano: es él quien necesita educación.

Por cierto, es posible que en un caso concreto la perplejidad del ciudadano sea más comprensible cuando la emisión autorizada por la administración constituya un acto que debería encontrarse prohibido conforme a la regulación legal y reglamentaria. El intento de evitar esta situación es otra de las razones que explican la regulación de los Arts. 167 y 168. En el contexto del proyecto, el uso de una técnica de accesoriedad de derecho por la vía de la remisión a un reglamento especial era reforzado mediante una prohibición legal — condicionada — de autorización de emisiones por encima del nivel fijado por ese reglamento (Art. $\left.9^{\circ} \mathrm{P}\right)^{90}$. El anteproyecto no sigue en esto al proyecto, entre otras razones, por lo anómalo que resultaría una regla semejante, propia de la legislación medioambiental, en el contexto de un Código Penal. No obstante, la concepción de los delitos de grave daño ambiental como atentados cuya ilicitud es en principio determinable por referencia exclusivamente a normas generales — las disposiciones penales y el reglamento al que se remiten ellas- se mantiene en el anteproyecto. Prueba de ello es el tratamiento que éste hace de los casos de actuación con infracción de normas administrativas particulares: tal como se ha visto, sólo los tematiza a propósito de los Arts. 169, 170 y 171.

${ }^{89}$ Matus (ed.), op. cit. supra, nota 2, pp. 123-125, 227-229.

${ }^{90}$ Que este procedimiento no elimina el riesgo de colusión entre la administración y los agentes contaminantes más relevantes para asegurar su impunidad ya ha sido advertido: basta con la fijación del nivel de emisión jurídico-penalmente relevante en un umbral lo suficientemente alto como para excluir la probabilidad de su infracción. 
La disociación que el proyecto y el anteproyecto hacen de los delitos de contaminación (Arts. 167 y 168) respecto del delito de atentado medioambiental con infracción administrativa (Art. 169) y del delito de incumplimiento del sistema de evaluación medioambiental (Art. 170) abre la interrogante acerca del estatus jurídico-penal de la producción de grave daño medioambiental cometida con cumplimiento de las condiciones y exigencias impuestas por la autoridad medioambiental. En particular, la disociación entre la imputación de responsabilidad por imprudencia (Art. 168) y la imputación de responsabilidad por infracción de reglamento (Art. 169), así como la acumulabilidad de las penas por la infracción administrativa (Art. 170), parecieran indicar que el anteproyecto se abre a la relevancia de estándares de cuidado debido distintos de los establecidos por la regulación — general y particular — administrativa, relevantes para la apreciación de la tipicidad dolosa e imprudente de los daños al medio ambiente.

Esta no es una concepción regulativa razonable.

El derecho penal debe aceptar que el sistema administrativo de gestión medioambiental determine no sólo el nivel de emisión que cuenta como daño al medio ambiente, sino también los estándares de cuidado debido en la producción y control del riesgo ambiental. De este modo, la producción de un daño en virtud de un riesgo permitido por la regulación administrativa debe contar como efecto de un riesgo permitido. Es posible que en casos excepcionales la prohibición penal se imponga a esa autorización frente a atentados dolosos o se abra a estándares indeterminados de cuidado para la apreciación de atentados imprudentes ${ }^{91}$. Pero en principio debe valer la consideración de la regulación administrativa como determinación jurídicopenalmente relevante del riesgo permitido en la creación y control del peligro para el ambiente ${ }^{92}$.

Con lo dicho queda planteada la solución al problema que ocasionaba la comprensible perplejidad del ciudadano: también debe aceptarse como principio general la eficacia excluyente de la ilicitud del acto administrativo impugnable por su ilicitud. Si el acto produce efectos institucionales mientras no sea anulado o revocado y si dentro de esos efectos se encuentra el de servir de norma de comportamiento para su destinatario, entonces tiene esa eficacia: la norma de comportamiento que autoriza excluye la ilicitud del comportamien-

${ }^{91} \mathrm{El}$ caso que más plausiblemente justifica esta excepción corresponde al daño al medio ambiente o peligro de ese daño vinculado a un cambio de circunstancias que no era previsible para la autoridad que otorgó la autorización (al respecto, en general, Steindorf, op. cit. supra nota 3, p. 52 s.).

${ }^{92}$ En sentido coincidente, desde la perspectiva de la responsabilidad por daños conforme al derecho privado, Barros Bourie, Enrique: Tratado de Responsabilidad Extracontractual, 2006, p. 802. 
to autorizado. Esta es la posición mayoritaria en la doctrina alemana ${ }^{93}$. También mayoritariamente la doctrina formuló una excepción a esta regla general, para el caso de obtención de la autorización con abuso del derecho, es decir, con engaño, coacción, cohecho u otra forma de colusión. Esta excepción fue reconocida en 1994 por el legislador (§ 330-d-(5) CP alemán).

En relación con esta cuestión el proyecto sólo contempla el caso de la autorización administrativa que autoriza emisiones superiores al nivel prohibido por el reglamento especial al que el proyecto se remite, autorización que como recién se ha visto el propio proyecto prohíbe en su Art 9º Para ese caso, el proyecto dispone que la autorización ilegal no excluye la ilicitud de la acción contaminante, pero le otorga un efecto atenuante a menos que haya sido obtenida con abuso del derecho (Art 15 AP). El anteproyecto generaliza esa decisión, estableciendo la misma regulación para todo caso de autorización obtenida “contra lo dispuesto expresamente en la ley o los reglamentos aplicables” (Art. 231). Ni la justificación de esta regla, ni su alcance, ni su significación como argumento de apoyo institucional para elaborar una respuesta general son claros.

La regla no se justifica desde el punto de vista del derecho público. Del hecho que la legislación administrativa chilena no efectúe la distinción entre nulidad del acto en el sentido de su inexistencia, y anulabilidad del acto en el sentido de su posibilidad de ser invalidado por posterior decisión administrativa o judicial $^{94}$, no cabe deducir el tratamiento de toda ilegalidad como inexistencia, sino más bien por el contrario, afirmar con carácter general el principio propio de la anulabilidad, es decir, que todo acto administrativo institucionalmente reconocible debe contar como válido mientras no sea anulado ${ }^{95}$. Por esta razón, las acciones realizadas de conformidad bajo un acto administrativo que produce sus efectos institucionales no pueden ser consideradas como acciones ilícitos.

${ }^{93}$ Para el caso de constituir la autorización un elemento del tipo -lo que usualmente corresponde a situaciones de prohibición legal preventiva con reserva de autorización administrativa—, el argumento de la doctrina se apoya principalmente en el principio de legalidad (Roxin, op. cit. supra, nota 39, p. 691). Para el caso de constituir la autorización una causa de justificación —lo que corresponde a situaciones de prohibición legal represiva con reserva de autorización administrativa - el argumento de la doctrina se apoya en consideraciones de unidad del ordenamiento jurídico, de seguridad jurídica y de protección de la confianza del ciudadano en la administración (Steindorf, op. cit. supra nota 3 p. 51 s.).

${ }^{94}$ Me refiero a la conocida distinción del derecho administrativo alemán entre la eficacia del acto (Wirksamkeit) pese a la existencia de vicios que puedan justificar su posterior revocación o invalidación, y su nulidad (Nichtigkeit) impeditiva de eficacia (§§ 43 y 44 de la Ley de procedimiento administrativo alemana).

${ }^{95}$ Para una exposición general acerca de la discusión sobre la nulidad de derecho público en la doctrina chilena, Jara Schnettler, Jaime: La Nulidad de Derecho Público ante la Doctrina y la Jurisprudencia, 2004, p. 27 s. La tesis de Jara acerca de la nulidad 
La regla tampoco se justifica desde el punto de vista del derecho penal, si la regulación punitiva adopta un modelo de dependencia relativa y accesoriedad de acto. Sólo un modelo de independencia absoluta o de exclusiva accesoriedad de derecho puede consistentemente desconocer la eficacia de los actos administrativos ilegales ${ }^{96}$. Esa era la pretensión del proyecto, tratándose de los delitos de contaminación. Pero esa pretensión fue abandonada por el anteproyecto en el Art. 169 y desmentida por los Arts. 170 y 171. Particularmente en el caso de estas dos últimas disposiciones, es evidente que el desconocimiento de la eficacia excluyente de la ilicitud de una autorización administrativa impugnable por ilegal resulta contradictorio con la definición del delito como comportamiento contrario a las decisiones de la administración.

¿Qué significa, por lo demás, la expresión “contra lo dispuesto expresamente por la ley o los reglamentos aplicables”? ¿Sólo se refiere a autorizaciones contrarias a prohibiciones expresas de la legislación o el reglamento, como es el caso del Art. $9^{\circ} \mathrm{P}$ ? ¿O cubre todos los casos en que la improcedencia de la autorización es determinable sin intervención de un margen institucional de apreciación o ponderación de su procedencia que sea de competencia de la administración? ¿Cuál es la consecuencia que de esta regla se deduce para el tratamiento de las autorizaciones ilícitas que sin embargo no fueron otorgadas bajo esa circunstancia? ¿Debe la ilegalidad general (material) primar sobre la legalidad parcial (formal) y en consecuencia extenderse a fortiori el ámbito de aplicación de la regla? ¿O más bien debe primar la legalidad parcial (formal) como consecuencia justificada por una interpretación a contrario de la regla?

La única regla correcta para una regulación penal de dependencia relativa con accesoriedad de acto es el desconocimiento excepcional de la eficacia excluyente de la ilicitud que tiene la autorización administrativa, incluso la impugnable por ilegalidad, en los casos de obtención de dicha autorización con abuso del derecho por parte de su destinatario. Esa regla expresa la falta de merecimiento de protección de la confianza del destinatario del acto, debido a su abuso, y permite extender la aplicabilidad de esa excepción a todos los casos de remisión de las normas penales a actos

administrativa coincide en los resultados con la apreciación que en el texto se hace de ella como anulabilidad (op. cit., p. 125 s.). La misma tesis es defendida en el derecho español por Santa María Pastor, Juan Alfonso: La Nulidad de Pleno Derecho de los Actos Administrativos, Madrid, 1972, especialmente p. 248 s.; siguiendo la tesis con una reformulación actualizada, Beladíez Rojo, Margarita: “La Nulidad y Anulabilidad: Su Alcance y Significación”, 1994, p. 155 s.

${ }^{96}$ Un ejemplo de esta postura, al menos en el nivel de proposición discursiva, se encuentra en Schünemann, “Zur Dogmatik...”, op. cit. supra, nota 3, especialmente p. $446 \mathrm{~s}$. 
administrativos, incluyendo los casos inequívocamente constitutivos de elementos del tipo penal ${ }^{97}$.

\section{El sistema de penas y demás consecuencias coercitivas}

Los Arts. 168 a 171 AP establecen como penas la privación de libertad y la multa. En una disposición aplicable a todos los delitos del título noveno de su libro segundo, el anteproyecto establece "medidas” con las cuales se “sanciona” a las personas jurídicas cuyos responsables o administradores sean condenados por esos delitos (Art. 229 AP), siempre que el delito haya sido cometido con infracción de un deber cuyo destinatario era la persona jurídica o de su ejecución se haya derivado o podido derivar un beneficio patrimonial para ésta. Salvo por estas condiciones, la regla — concebida directamente como norma sancionatoria — tiene su origen en el proyecto (Art. 14 P).

Los problemas planteados por la atribución de responsabilidad penal a las personas jurídicas y la aplicación coercitiva de consecuencias jurídicas a ellas con ocasión de la condena por la comisión de delitos al interior de su organización exceden, por supuesto, el ámbito del derecho penal medioambiental. Los delitos contra el ambiente sólo representan un caso particular de criminalidad empresarial ${ }^{98}$. Esa razón y la extensión que ya tiene este comentario justifican que esta sección se limite a la afirmación de un par de cuestiones de principio.

${ }^{97}$ Pendientes quedan otras dos cuestiones, no tematizadas por el anteproyecto: (i) el tratamiento de la situación inversa a la examinada, es decir, la actuación prohibida en particular por la administración pero realizada de conformidad a todos los presupuestos de las normas generales (prohibición administrativa ilícita); (ii) la responsabilidad del funcionario público que autoriza ilícitamente la realización de acciones materialmente relevantes como delitos medioambientales. La solución a la primera cuestión depende de una consideración de diseño institucional más amplio: ¿hasta dónde está dispuesto el legislador a someter a control judicial las decisiones administrativas que excluyen riesgos para el medio ambiente? La solución a la segunda depende de la consideración de si una regla de esa naturaleza implicaría un trato discriminatorio para los funcionarios de este sector de la administración pública y de si semejante regla inhibiría su colaboración en la investigación de los delitos medioambientales; vencidas esas dos aprehensiones, el establecimiento de un delito especial de prevaricación debe efectuarse de modo que no entre en conflicto con la posible imputación de coautoría o complicidad al funcionario. Al respecto, Cancio Meliá, Manuel: "La Responsabilidad del Funcionario por Delitos contra el Medio Ambiente en el Código Penal Español”, 2005, p. 295.

${ }^{98}$ De aquí que el establecimiento de esta regla sancionatoria dentro del título noveno del libro segundo del anteproyecto sea incongruente. Los delitos de peligro colectivo no son los únicos ni los principales casos de criminalidad al interior de la empresa. La regla debería establecerse en la parte general de un Código y comprender también los delitos socioeconómicos. Para un tratamiento del problema en general, pese a su referencia al derecho penal del medioambiente, Feijoo Sánchez, Bernardo José: Sanciones para Empresas por Delitos contra el Medio Ambiente, 2002, especialmente p. 113 s. 
El principio de proporcionalidad prohíbe al Estado la afectación de derechos fundamentales que aparece como innecesaria en relación con el fin perseguido. La asunción usual es que esta prohibición de exceso hace del derecho penal un medio estrictamente subsidiario o de uso como ultima ratio respecto de todos los posibles medios institucionales disponibles e idóneos para el logro del fin. En rigor, sin embargo, la prohibición de exceso produce ese efecto en relación con las restantes intervenciones sancionatorias de que dispone el Estado, particularmente el derecho administrativo sancionatorio. Ello, por la obvia razón de que la operatividad del principio exige conmensurabilidad de los medios alternativos, y tratándose de medios preventivos o de naturaleza directamente instrumental falla el presupuesto de la condición lingüísticamente mediada del control normativo del comportamiento ${ }^{99}$.

La primera pregunta, por lo tanto, es propia del derecho medioambiental: ¿qué modo de intervención estatal debe ser privilegiado para proteger el medio ambiente? El derecho penal se arroga competencia para responder a la segunda pregunta, en términos negativos: allí donde se requiera la concurrencia de normas sancionatorias, la prioridad la tiene el derecho administrativo sancionador.

De las múltiples razones que pueden esgrimirse para revertir la respuesta anterior y recurrir justificadamente a la pena dos parecen ser las más relevantes. La primera, la necesidad de contar con los recursos de investigación propios del procedimiento penal —sus medidas intrusivas y coercitivas - de los cuales carece la fiscalización administrativa. Esta es un arma de doble filo: por una parte puede conducir al reforzamiento de los procedimientos administrativos de fiscalización, y por la otra parte, si se remite al procedimiento penal, incorpora necesariamente una nueva institución con prerrogativa de decisión acerca la procedencia de la investigación y acusación y también acerca de la interpretación de las normas sancionatorias ${ }^{100}$.

${ }^{99}$ La falta de conmensurabilidad entre intervenciones estatales lingüísticamente mediadas e intervenciones estatales directamente instrumentales impide considerar a la intervención punitiva como a priori más lesiva de la libertad que cualquier otra intervención. Reconociendo esta inconmensurabilidad y presentándola como una paradoja —la intervención punitiva garantiza una mayor libertad—, Stächelin, op. cit., supra nota 12, p. 133 s.

${ }^{100}$ La disparidad de criterios entre los órganos prosecutores de responsabilidad penal y los órganos fiscalizadores del cumplimiento de la regulación administrativa es reconocidamente uno de los problemas básicos del derecho penal medioambiental norteamericano. Al respecto, Lazarus, "Meeting...”, op. cit. supra nota 3, loc. cit.; Schiffer, Lois J. y James Simon: "The Reality of Prosecuting Environmental Criminals: A Response to Professor Lazarus", 1995; Lazarus, Richard: "The Reality of Environmental Law in the Prosecution of Environmental Crimes: A Reply to the Department of Justice”, 1995b; Babbit, Charles, Denis C. Cory y Beth L. Kruckek, "Discretion and the Criminalization of Environmental Law”, 2005. 
La segunda razón es la significación social o función expresiva de la pena $^{101}$. Esta razón exige que la pena sea definida como irrogación de un mal sujeto a estándares particularmente estrictos de distribución, que exigen una alta selectividad y concentración de su efecto: sólo el infractor de la norma debe asumir el costo de su infracción expresado en la pena. Esta nodistribuibilidad de la pena es obvia bajo una concepción retribucionista: la exigencia de culpabilidad es una prohibición de distribución del costo de la pena más allá de la atribución de responsabilidad. Pero también lo es para una concepción utilitarista, en la medida en que la no-distribuibilidad constituye un presupuesto de la eficacia estratégica de la práctica punitiva ${ }^{102}$.

Aun dejando de lado todas las cuestiones relativas al sentido (o falta de sentido) que pueda tener el trato a las organizaciones de personas como interlocutores normativos o agentes con racionalidad de fines, es claro que la pena de multa dirigida contra la persona jurídica difícilmente puede satisfacer la exigencia de no distribuibilidad. Lo decisivo tratándose de una consecuencia patrimonial adversa es que no pueda ser asumida por la persona jurídica como un costo de operación. Para ello se requeriría, en primer término, un sistema de determinación judicial de la multa que otorgara al tribunal un amplísimo margen de apreciación de su cuantía. Pero satisfacer ese requisito haría a la pena de multa por definición institucional imprevisible y por lo mismo entraría en tensión con el principio de legalidad. Y aun si se dispusiera de ese margen de apreciación judicial, la determinación de la multa óptima requeriría un nivel prácticamente inalcanzable de información en el sentenciador y condiciones de competencia perfecta en el mercado para la empresa. Por eso, lo usual es que esa determinación fracase, y que la multa se vea enfrentada al dilema de arruinar a la empresa o ser asumida por ésta como un costo de operación. Este último caso sí que deja perplejo al ciudadano: no sólo padece como miembro de la comunidad interesado en la preservación del medio ambiente el daño que le causa una empresa, sino que además tiene que soportar en definitiva como consumidor el costo de la infracción.

De aquí que la intervención del derecho penal en el ámbito del derecho medioambiental, como en todo otro ámbito predominantemente abarcado por el derecho administrativo sancionatorio, debe priorizar la pena individual y particularmente la pena privativa de libertad, que representa la expresión más significativa de un costo intransferible.

${ }^{101}$ Para una aplicación de las consideraciones expresivas de la pena al derecho medioambiental norteamericano, Hedman, Susan: "Expressive Functions of Criminal Sanctions in Environmental Law”, 1991.

${ }^{102} \mathrm{Al}$ respecto, Von Hirsch, Andrew: Censurar y Castigar, 1998, especialmente p. $31 \mathrm{~s}$. 
Tratándose de las personas jurídicas, mucho más importante que la imposición de una pena de multa es el diseño de un régimen de comiso de ganancias obtenidas por el delito, y de un régimen de medidas de intervención que permitan un control preventivo directo, especialmente en casos de constatación de falta de responsabilidad organizada (la empresa como sujeto peligroso) o de constatación de su carácter instrumental delictivo (la empresa como objeto peligroso). El anteproyecto carece de esos instrumentos.

En lo que respecta a la imposición de consecuencias patrimonialmente adversas, éstas no pueden verse expuestas por el propio legislador a perder el sentido preventivo que pudieran revestir a pesar de las dificultades arriba aducidas. Por esta razón, una regla de compensación de la multa con cargo a los gastos realizados para la reparación del daño, como la establecida por el anteproyecto (Art. 230 AP) siguiendo al proyecto (Art. 14 inciso final P) es sencillamente inaceptable: semejante regla constituye un incentivo para la comisión de delitos sancionados con multa, porque diluye por completo su efecto disuasivo ${ }^{103}$.

Desde el punto de vista del interés en la preservación del medio ambiente, mucho más relevante que una regla de compensación es el establecimiento de una regla de exención de pena para el caso de evitación del daño con posterioridad a la comisión de un delito de peligro. Esa inconsistencia legislativa formal — eximir de pena por un comportamiento posterior a la consumación - es la mejor manera que tiene el legislador de mantener consistencia material — evitar el daño como razón de la anticipación de la punición al peligro-.

\section{Conclusiones}

Tratándose de la configuración del derecho penal del medio ambiente, el legislador debe adoptar un considerable número de decisiones sistemáticas. El anteproyecto reconoce esas cuestiones sistemáticas e intenta adoptar una decisión correcta al respecto. Cada una de sus decisiones, no obstante, constituye un intento fallido.

1. El legislador debe decidir si considera al medio ambiente como un bien colectivo merecedor de protección penal o si sólo lo considera como una fuente de peligro común para bienes individuales. En uno y otro caso, la decisión debe ser tematizada explícitamente y la regulación que se esta-

${ }^{103}$ En este punto el proyecto francamente confunde la relevancia de la obtención de reparación con la procedencia de su compensación con la multa (op. cit., p. 122 s.). El aseguramiento de la reparación debe obtenerse, primero mediante obligaciones administrativas de contratación de seguros y luego con el otorgamiento al ministerio público de la competencia para interponer las acciones de reparación que sean procedentes bajo la consideración del daño como afectación de bienes fiscales o nacionales de uso público. 
blezca debe ser consistente con esa decisión. El anteproyecto falla en este aspecto: tematiza a los delitos relativos al medio ambiente como fuente de peligro común para bienes individuales pero los tipifica como atentados contra un bien colectivo (sección 4).

2. El legislador debe hacerse cargo de la variedad y distinta gravedad de las alteraciones del ambiente prohibidas por la regulación administrativa, estableciendo diferenciaciones básicas relativas criterios de merecimiento y necesidad de pena. El anteproyecto falla en este sentido: reduce la protección penal del daño ambiental a los actos prohibidos por las normas de emisión y da un mismo tratamiento a todas esas emisiones (sección 5.1).

3. El legislador debe decidir si considera que la producción de daño al medio ambiente correspondiente al nivel de la prohibición administrativa de emisiones contaminantes es por sí sola un comportamiento merecedor de pena, o si condiciona ese merecimiento a la satisfacción de condiciones más exigentes, relativas al carácter catastrófico del daño o al abuso grave de los procedimientos de control administrativo del riesgo medioambiental. El anteproyecto falla en este aspecto: considera que el nivel de la prohibición administrativa de la emisión es jurídico-penalmente irrelevante pero se conforma con que tenga un nivel superior, fijado por la misma administración, bajo criterios ajenos a la formulación de las normas de emisión (sección 5.2).

4. El legislador debe decidir si considera al peligro para la vida y la salud de las personas generado por el daño ambiental como un peligro abstracto o como un peligro concreto. El proyecto falla en este aspecto: lo considera como un peligro concreto pero ordena a la administración su determinación ex-ante, lo que sólo es posible de hacer respecto de un peligro abstracto (sección 5.3).

5. El legislador debe establecer un régimen general de concurso de delitos que otorgue tratamiento satisfactorio a la variedad de casos concursales que sean reconocibles como los más relevantes. Las reglas especiales concursales que establezca deben ser coherentes en sus resultados con ese régimen general. El anteproyecto falla en este sentido: establece un régimen general que altera a propósito de la concurrencia de homicidio o lesiones dolosas, cuyas reglas vuelve a alterar a propósito de la producción de muerte o lesiones como consecuencia del daño ambiental; el tratamiento dado por estas reglas especiales a los casos de muertes o lesiones masivas implica un privilegio en comparación con el régimen general de concurso de delitos (sección 5.4).

6. El legislador debe reconocer la dependencia de las normas penales de la regulación administrativa, asumiendo para la mayoría de los casos de daño ambiental la accesoriedad de acto, aceptando el efecto determinante de los actos administrativos sobre la ilicitud penal. El anteproyecto falla en este aspecto: debido a su concentración en la cuestión de la determinación de la 
magnitud del daño jurídico-penalmente relevante no reconoce en su regulación la incidencia de la regulación administrativa — general y particular — en la definición del riesgo ambiental permitido (secciones 6 , 7, 8 y 10).

7. El legislador debe abstenerse de reforzar penalmente toda elusión de los procedimientos administrativos, incumplimiento de condiciones de la administración o infracción de sus exigencias, y debe reservar la pena para el caso en que esa elusión, incumplimiento o infracción revista especial gravedad. El anteproyecto falla en este aspecto: tipifica como delito toda elusión, incumplimiento o infracción cometida respecto del sistema de evaluación de impacto ambiental (sección 7).

8. El legislador debe considerar como comportamiento merecedor de pena el manejo ilegal de desechos peligrosos para la vida y salud de personas, animales o plantas, así como para el medio ambiente. El anteproyecto falla en este sentido: la disposición relativa al manejo indebido de sustancias tóxicas y peligrosas no cubre adecuadamente el tratamiento de desechos (sección 8).

9. El legislador debe establecer reglas de imputación que permitan hacer responsables a quienes detentan posiciones de control al interior de las organizaciones de personas. El anteproyecto falla en este aspecto: incorpora la regla que pretende establecer a la descripción típica, formulándola como norma de comportamiento y generando con ello consecuencias absurdas (sección 9).

10. El legislador debe demostrar consistencia con una opción sistemática por la accesoriedad de acto; eso exige reconocer como principio la eficacia de los actos administrativos que conceden o deniegan permisos, incluso tratándose de actos impugnables, con la expresa excepción de los casos de obtención de un permiso mediante abuso del derecho. El anteproyecto falla en este sentido: establece una regla de irrelevancia de un caso de autorización ilegal que carece de justificación y que deja en la incertidumbre el tratamiento de los demás casos (sección 10).

11. El legislador debe impedir que las consecuencias impuestas coercitivamente a las personas jurídicas por los delitos cometidos al interior de su organización representen meros costos de operación para esas organizaciones. El anteproyecto falla en este aspecto: carece de un régimen efectivo de comiso de ganancias y al establecer la posibilidad de compensación de la multa con los pagos efectuados para reparar el daño causado diluye su posible efecto disuasivo (sección 11).

A la luz de estos resultados se impone una última conclusión. Al inicio de este comentario se advirtió que quizás no hubiera llegado aún entre nosotros la hora del derecho penal en materia de la protección del medio ambiente. Ahora puede añadirse como algo seguro que a la vista del proyecto y del anteproyecto aún no contamos con una propuesta legislativa viable al respecto. 
ANEXO

Cuadro comparativo entre el Anteproyecto de Nuevo Código Penal (2005)

y el Proyecto de Ley sobre Delitos contra el Medio Ambiente (2004)

\section{Anteproyecto de Nuevo Código Penal}

Art. 167. El responsable o administrador de un proyecto o actividad que en su operación produzca un grave daño ambiental, será castigado con la pena de reclusión menor en su grado medio y multa de dos mil a tres mil unidades tributarias mensuales.

La pena será el máximum de la señalada en el inciso anterior y multa de tres mil a cinco mil unidades tributarias mensuales, si el grave daño ambiental a que se refiere el inciso anterior pone en serio peligro la vida o la salud de personas determinadas.

Si el grave daño ambiental produce lesiones de las contempladas en el artículo 85 y $87 \mathrm{~N}^{\circ} 2$ de este código a una o más personas, se aplicará la pena de reclusión menor en su grado máximo y multa de cuatro mil a cinco mil unidades tributarias mensuales.

La pena será de reclusión menor en su grado máximo a mayor en su grado mínimo y multa de cinco mil a siete mil unidades tributarias si las lesiones producidas son las del $\mathrm{N}^{0} 1$ del artículo 87.

Si el grave daño ambiental produce la muerte de una o más personas, la pena será de reclusión mayor en sus grados mínimo a medio y multa de siete mil a diez mil unidades tributarias mensuales.

Art. 168. El responsable o administrador de un proyecto o actividad que por imprudencia en su operación produzca un grave daño ambiental, será
Proyecto de Ley

Art. $1^{\circ}$. El responsable de una fuente emisora que produzca una grave pérdida, disminución, detrimento o menoscabo al medio ambiente o a uno o más de sus componentes, será castigado con la pena de presidio menor en su grado máximo y multa de 2.000 a 3.000 Unidades Tributarias Mensuales.

La pena será de presidio mayor en su grado mínimo y multa de 3.001 a 5.000 Unidades Tributarias Mensuales, si el grave daño ambiental a que se refiere el inciso anterior pusiere en serio peligro la vida o la salud de las personas.

Si de resultas del delito se causare efectivamente la muerte o lesiones graves de una o más personas, la pena será de presidio mayor en cualquiera de sus grados y multa de 5.001 a 7.000 Unidades Tributarias Mensuales; a menos que el delito se hubiere cometido con la intención de lesionar gravemente o causar la muerte de una o más personas determinadas, caso en el cual la pena será la de presidio mayor en su grado máximo a presidio perpetuo calificado y multa de 7.001 a 10.000 Unidades Tributarias Mensuales.

Art. $2^{\circ}$. El responsable de una fuente emisora que por negligencia o incumplimiento de las disposiciones legales o reglamentarias causare un grave 
castigado con la pena de reclusión menor en su grado mínimo y multa de dos mil a cuatro mil unidades tributarias mensuales.

La pena corporal será de reclusión menor en su grado mínimo a medio si el grave daño ambiental pone en peligro la vida o la salud de personas determinadas; y de reclusión menor en su grado medio, si produce alguna de las lesiones de los artículos 85 y 87 a una o más personas.

Si el grave daño ambiental produce la muerte de una o más personas, la pena corporal será de reclusión menor en su grado máximo a mayor en su grado mínimo. En todos los casos en que del grave daño ambiental se deriven lesiones o muertes, la pena pecuniaria no podrá ser inferior a tres mil unidades tributarias mensuales.

Art. 169. Las mismas penas señaladas en el artículo anterior se impondrán a los responsables o administradores de un proyecto o actividad que contando con una autorización o una certificación ambiental para su operación, produzcan un grave daño ambiental por el incumplimiento de las condiciones o exigencias bajo las cuales se les otorgó la certificación y los permisos correspondientes o que ponga en serio peligro la vida o la salud de una o más personas determinadas o les provoque lesiones o muerte, sin perjuicio de las responsabilidades y sanciones administrativas correspondientes.

Art. 170. El responsable o administrador de un proyecto o actividad que conforme a la Ley deba someterse al sistema de evaluación de impacto ambiental, lo ejecute o mande a ejecutar sin hacerlo previamente, será castigado con una multa de mil a tres mil unidades tributarias mensuales, sin perjuicio daño ambiental, en los términos del artículo anterior, será castigado con la pena de reclusión menor en su grado medio y multa de 2.001 a 3.000 Unidades Tributarias Mensuales. La pena corporal será de reclusión menor en su grado máximo si se pusiere en serio peligro la vida o la salud de las personas; y de reclusión mayor en su grado mínimo, si se causare efectivamente la muerte o lesiones graves de una o más personas.

\section{(...)}

Las mismas penas se impondrán a los que habiendo obtenido la aprobación del Estudio o aceptación de la Declaración de Impacto Ambiental de un proyecto o actividad, causaren un grave daño ambiental por el incumplimiento de las condiciones o exigencias ambientales bajo las cuales se les otorgó la certificación ambiental y los permisos correspondientes, sin perjuicio de las responsabilidades y sanciones administrativas aplicables conforme lo dispuesto en el artículo 64 de la Ley $\mathrm{N}^{\circ}$ 19.300, sobre Bases Generales del Medio Ambiente.

Art. $4^{\circ}$. El que ejecute o mande ejecutar un proyecto o actividad de los señalados en el art. 10 de la Ley $\mathrm{N}^{\circ}$ 19.300, sin previamente haber sometido dicho proyecto o actividad al Sistema de Evaluación de Impacto Ambiental, de acuerdo a lo establecido en dicha ley, sufrirá la pena de multa de 
de las penas que correspondan por la comisión de alguno de los delitos descritos en los artículos anteriores.

(...)

(...)

La misma pena se impondrá al responsable o administrador de un proyecto o actividad que, habiéndose sometido al sistema de evaluación de impacto ambiental, lo ejecute o mande a ejecutar en términos diversos a los que fueron aprobados o autorizados.

Art. 171. El administrador o responsable de un proyecto o actividad que sin la competente autorización extraiga, produzca, transforme, transporte, distribuya, venda, compre, importe o exporte, guarde o almacene sustancias tóxicas o peligrosas en cantidades tales que constituyan un serio peligro de grave daño ambiental, será castigado con la pena de reclusión menor en su grado mínimo y multa de tres mil a cinco mil unidades tributarias mensuales.

Si el peligro a que se refiere el inciso anterior incluyese un serio riesgo para la salud o la vida de personas determinadas, la pena será de reclusión menor en su grado medio y multa de tres mil a cinco mil unidades tributarias mensuales.
5.000 a 10.000 Unidades Tributarias Mensuales, sin perjuicio de las penas que correspondan por la comisión de alguno de los delitos descritos en el Título anterior, en su caso.

(...)

(...)

Se impondrá, además, la pena de reclusión menor en su grado medio, si se actuase en contra de las instrucciones o resoluciones de la autoridad ambiental.

Art. $5^{\circ}$. El que habiendo obtenido la aprobación de la Declaración o Estudio de Impacto Ambiental correspondiente a su actividad o proyecto, lo modifique o mande modificar sin someter previamente esa modificación a la evaluación de su impacto ambiental, cuando ello corresponda, será castigado con la pena de multa de 5.000 a 7.000 Unidades Tributarias Mensuales, sin perjuicio de las penas que deban imponerse por la comisión de alguno de los delitos descritos en el Título anterior, en su caso.

Art. $3^{\circ}$. El que sin la competente autorización extrajere, produjere, transformare, transportare, vendiere, comprare, importare o exportare, guardare o almacenare sustancias tóxicas o peligrosas en cantidades tales que constituyan un serio peligro de grave daño ambiental, será castigado con la pena de reclusión menor en su grado medio y multa de 2.000 a 3.000 Unidades Tributarias Mensuales.

(...)

Si el peligro a que se refiere el inciso anterior incluyese un serio riesgo para la salud o la vida de las personas, la pena será de reclusión menor en su grado máximo y multa de 3.001 a 5.000 unidades tributarias mensuales. 
Las mismas penas se impondrán al responsable o administrador de un proyecto o actividad que, habiendo obtenido la autorización a que se refiere el inciso primero, incumpla sus condiciones u obligaciones.

172. Un reglamento determinará las sustancias y cantidades o proporciones de contaminantes provenientes de una misma fuente emisora cuya emisión al medio ambiente constituya un grave daño ambiental en los términos descritos en los artículos 167 y 168, y las que en su caso, pongan en serio peligro la vida y la salud de personas determinadas expuestas a él.

Este reglamento sólo podrá considerar como constitutiva de un grave daño ambiental, la emisión de sustancias contaminantes en cantidades o proporciones significativamente superiores a los máximos señalados en las Normas de Emisión que sean aplicables.

El reglamento también determinará las cantidades de las sustancias tóxicas o peligrosas a que se refiere el artículo 171 respecto de las cuales las conductas allí señaladas constituyan un serio peligro de grave daño ambiental, y las que, en su caso, constituyan un serio riesgo para la vida y la salud de personas determinadas.

173. Las disposiciones de los artículos precedentes no serán aplicables a las emisiones provenientes de vehículos sujetos a inscripción en el Registro Nacional de Vehículos Motorizados, chimeneas y demás sistemas de calefacción o refrigeración domésticos, las que, en caso de exceder las Normas de Emisión correspondientes, se regirán por las disposiciones generales aplicables en la materia.
Art. $8^{\circ}$. Un reglamento determinará las sustancias y cantidades o proporciones de contaminantes provenientes de una misma fuente emisora cuya emisión al medio ambiente constituya un grave daño ambiental y, en su caso, de poner en serio peligro la vida y la salud de las personas.

Dicho reglamento no podrá considerar como capaces de producir un grave daño ambiental, cantidades o proporciones de sustancias contaminantes iguales o inferiores a los máximos señalados en las normas de emisión que sean aplicables.

Art. 10. Las disposiciones de esta ley no serán aplicables a las emisiones provenientes de vehículos sujetos a inscripción en el Registro Nacional de Vehículos Motorizados, chimeneas y demás sistemas de calefacción o refrigeración domésticos, las que, en caso de exceder las normas de emisión correspondientes, se regirán por las disposiciones generales aplicables en la materia. 
Art. 228. Para los efectos de lo dispuesto en este Título, se entenderán como responsables o administradores de una empresa, proyecto o actividad los que lo sean de hecho o de derecho $\mathrm{y}$, especialmente, sus representantes, directores y gerentes.

Respecto de estas personas, y sin perjuicio de las reglas generales, se estimará suficiente prueba para eximirlas de responsabilidad penal por alguna de las conductas sancionadas en este Título, la de haberse opuesto al acto u omisión que constituye el delito, intentando seriamente evitar su realización; o mediante el establecimiento previo de medidas de control administrativo que sus subordinados hubiesen infringido, sin su conocimiento o sin que les fuese posible evitarlo, por provenir de acciones de sabotaje u otras intervenciones de terceros de similares características.

En el caso de los directores o gerentes de una persona jurídica, su oposición al acto que constituye el delito, podrá acreditarse con la sola exhibición de las actas correspondientes a la sesión del directorio en que se decidió su realización.

En caso de sabotaje o intervención de terceros de similares características, se sancionará con las mismas penas previstas para los responsables o administradores de la empresa, proyecto o actividad, a quienes lo sean del sabotaje o la intervención de que se trate.

Art. 229. Las personas jurídicas cuyos responsables o administradores sean condenados por alguno de los delitos previstos en este Título, serán sancionadas por el Tribunal que conozca de dicho delito, sin perjuicio de las sanciones civiles y administrativas correspondientes, con una o más de las siguientes medidas:
Art. 13. Sin perjuicio de las reglas generales, se considerarán también autores por los delitos comprendidos en esta ley los que aparezcan ante la Comisión Nacional o Regional del Medio Ambiente, según corresponda, como titulares de los proyectos o actividades en que incida el delito, y tratándose de personas jurídicas, sus representantes legales, gerentes o directores, y en general, todos quienes tengan o compartan de hecho o jurídicamente facultades de administración de la misma, salvo prueba en contrario.

Se estimará suficiente prueba para eximir de la responsabilidad penal a las personas señaladas en el inciso anterior, la de haberse opuesto al acto u omisión que constituye el delito, intentando seriamente evitar su realización; o mediante el establecimiento previo de medidas de control administrativo que sus subordinados hubieren infringido, sin su conocimiento o sin que le fuese posible evitarlo, por provenir de acciones de sabotaje u otras intervenciones de terceros de similares características.

En el caso de los directores o gerentes de una persona jurídica, su oposición al acto que constituye el delito podrá acreditarse con la exhibición de las actas correspondientes a la sesión del Directorio en que se decidió su realización.

Art. 14. Las personas jurídicas cuyos representantes, gerentes, directores o administradores, de hecho o de derecho, fueren condenados por alguno de los delitos previstos en esta ley, cometido durante el desarrollo de un proyecto o actividad de dicha persona jurídica, serán sancionadas por el tribunal que conozca de dicho delito, sin perjuicio 
a) Multa de entre trescientas a quince mil Unidades Tributarias Mensuales, de acuerdo a la gravedad de la infracción y al patrimonio de la empresa sancionada;

b) Revocación de las autorizaciones infringidas; 0

c) Clausura definitiva del proyecto o empresa en que incide el delito;

En todo caso deberá decretarse además la inscripción de la sanción en un registro público especial que llevará la Contraloría General de la República. Un reglamento regulará las formalidades de este registro, cuyas inscripciones deberán ser tomadas en cuenta para evaluar la seriedad de las garantías de los proyectos o empresas sujetos por el Estado a concurso público o privado.

Las medidas señaladas en este artículo sólo se aplicarán cuando los delitos cometidos consistan en la infracción de un deber impuesto a la persona jurídica en el desarrollo del proyecto o actividad de que se trate, o cuando de su ejecución derive o pueda derivar un beneficio patrimonial para la empresa sancionada.

Art. 230. Las multas impuestas por la comisión de alguno de los delitos de este Título, o en virtud de lo dispuesto en el artículo anterior, podrán compensarse con los gastos que voluntaria y efectivamente se hubieran realizado para eliminar el peligro creado por el delito, reparar el daño producido o indemnizar a las personas afectadas, cuando corresponda.

Art. 231. Sin perjuicio de lo dispuesto en los artículos tercero y cuarto de este Código, la aprobación por parte de la de las acciones civiles y administrativas correspondientes:

a) Con la clausura del proyecto o actividad en que incide el delito;

b) Con una multa de entre $10.000 \mathrm{y}$ 15.000 Unidades Tributarias Mensuales; $\mathrm{y}$,

c) Con la inscripción en un registro público especial que llevará la Comisión Nacional del Medio Ambiente. Un reglamento regulará las formalidades de este registro, cuyas inscripciones, en todo caso, deberán ser tomadas en cuenta para evaluar la seriedad de las garantías medioambientales de los proyectos o actividades sujetos al sistema de evaluación de impacto ambiental. (...)

\section{(...)}

La multa podrá compensarse con los gastos que voluntaria y efectivamente se hubieran realizado en orden a recuperar el medio ambiente e indemnizar a las personas afectadas, cuando corresponda. En estos casos, el tribunal podrá, además, abstenerse de clausurar el proyecto o actividad, siempre que se produzca una recuperación seria del medio ambiente dañado y una indemnización satisfactoria a las personas afectadas, ordenando dejar constancia de esta circunstancia en el registro señalado en la letra c) anterior.

Art. 15. La aprobación por parte de la Comisión Nacional o Regional del Medio Ambiente, según corresponda, de 
autoridad administrativa de una empresa o actividad contra lo dispuesto expresamente en la ley o en los reglamentos aplicables, no exime de la responsabilidad penal y sólo podrá considerarse como circunstancia atenuante en la comisión de los delitos contemplados en este Título, a menos de probarse que el responsable de los mismos hubiere obtenido dicha aprobación en connivencia con los funcionarios que indebidamente la otorgaron.

Art. 232. Sin perjuicio de las reglas generales, podrá tenerse por probado que la operación de un proyecto o actividad ha producido efectivamente lesiones graves o la muerte de una o más personas determinadas, si se cumplen los siguientes requisitos:

a) Que exista prueba de que una o varias personas determinadas estuvieron un Estudio o Declaración de Impacto Ambiental en contra de lo previsto en el Art. $9^{\circ}$ de esta ley no producirá otro efecto que el de ser circunstancia atenuante en la comisión de los delitos contemplados en el Tit. I de esta ley, a menos de probarse que el responsable de los mismos se hubiere concertado con los funcionarios que indebidamente aprobaron el proyecto o actividad origen del grave daño ambiental que se trate, caso en el cual esta última circunstancia se considerará como agravante, sin perjuicio de las penas que pudieran corresponder por los delitos de cohecho, negociación incompatible, tráfico de influencias y demás que pudieran haberse cometido.

Art. 11. La existencia de una prueba pericial acerca del hecho de haberse emitido al medio ambiente las cantidades o proporciones de sustancias contaminantes que el reglamento determine como capaces de producir un grave daño ambiental o un serio peligro para la vida y la salud de las personas, en su caso, será suficiente para presumir judicialmente o dar por establecido conforme a los conocimientos científicos asentados, que efectivamente se ha producido un grave daño ambiental, con peligro para la salud y la vida de las personas, en su caso, según lo dispuesto en los arts. 488 del Código de Procedimiento Penal y 297 del Código Procesal Penal, respectivamente.

Art. 12. Sin perjuicio de las reglas generales, y salvo prueba en contrario, se tendrá por probado según lo dispuesto en los arts. 488 del Código de Procedimiento Penal y 297 del Código Procesal Penal, respectivamente, que una emisión considerada por el reglamento como capaz de producir un serio peligro para la salud y la vida de las perso- 
expuestas al peligro producido por el proyecto o actividad, con anterioridad a sus lesiones o muerte;

b) Que exista prueba pericial que aporte una explicación general sobre los procesos biológicos, químicos o físicos que desencadenan en las personas la exposición al peligro de que se trate; $y$

c) Que exista prueba pericial de que en las personas lesionadas o muertas se desencadenaron similares procesos a los mencionados en la letra anterior, después de su exposición al peligro de que se trate.
Art. 233. Para efectos de lo dispuesto en este Título, las expresiones técnicas se entenderán en el sentido de lo dispuesto en las leyes especiales y reglamentos aplicables. nas, ha causado efectivamente lesiones graves o la muerte de una o más personas determinadas, si se cumplen las siguientes condiciones:

a) Que exista una prueba pericial de que la emisión capaz de poner en peligro la vida y la salud de las personas se produjo con anterioridad a las lesiones o muerte de una o más personas;

b) Que exista una prueba pericial de que una o varias personas estuvieron expuestas a los contaminantes emitidos por un tiempo y en cantidades suficientes para que, según los conocimientos médicos asentados, dichas personas pudiesen ser afectadas por ellos; $y$

c) Que exista prueba pericial que aporte una explicación sobre el mecanismo biológico, químico o físico desencadenado en la persona o personas afectadas por los efectos de su exposición a la emisión contaminante.

Para la aplicación de lo dispuesto en este artículo bastará un único informe pericial, si él contiene las conclusiones que sirven de base a la presunción judicial o a la afirmación, conforme a los conocimientos científicos asentados, de haberse producido los hechos antes enumerados. 


\section{REFERENCIAS BIBLIOGRÁFICAS}

Alastuey Dobón, María del Carmen: El Delito de Contaminación Ambiental (Art. 325.1 del Código Penal). Granada: Editorial Comares, 2004.

Alcácer Guirao, Rafael: "La Protección del Futuro y los Daños Acumulativos”. En Revista Electrónica de Ciencia Penal y Criminología No 4 (2002). (Disponible en: http:// criminet.ugr.es/recpc/recpc_04-08.html).

Alternativ-Entwurf eines Strafgesetzbuche, Allgemeiner Teil (Volumen conjunto), preparado por Jürgen Baumann, Stephan Quensel y otros, 1969.

Appel, Ivo: Verfassung und Strafe (Constitución y pena). Berlin: Duncker \& Humblot, 1998.

Asenjo, Rafael: “Institucionalidad Pública y Gestión Ambiental en Chile”. Serie en Foco, № 89, Expansiva, Santiago, 2006.

Babbit, Charles, Denis C. Cory y Beth L. Kruckek: "Discretion and the Criminalization of Environmental Law”. En Duke Environmental Law \& Politics Forum, 15 (2005).

Barreiro, Agustín Jorge (director): Estudios sobre la Protección del Medio Ambiente en el Ordenamiento Jurídico Español. Granada: Editorial Comares, 2005.

Barros Bourie, Enrique: Tratado de Responsabilidad Extracontractual. Santiago: Editorial Jurídica de Chile. 2006.

Barton, Jonathan, Francisca Reyes, Priscilla Álamos, Sergio Galilea y Manuel J. Prieto: "El Nuevo Diseño de la Institucionalidad Ambiental en Chile”. En Pontificia Universidad Católica de Chile (ed.), Camino al Bicentenario: Propuestas para Chile. Santiago: Pontificia Universidad Católica, 2007.

Bascuñán Rodríguez, Antonio: “El Robo como Coacción”. En Revista de Estudios de la Justicia $\mathrm{N}^{\circ} 1$ (2002).

"Derechos Fundamentales y Derecho Penal". En Marcelo Alegre y otros, Los Derechos Fundamentales. Seminario en Latinoamérica de Teoría Constitucional y Política (SELA) 2001. Buenos Aires: Ediciones del Puerto s.r.l., 2002. [También en Revista de Estudios de la Justicia № 9 (2007).] Confirmar si está bien el título del libro.

Beladíez Rojo, Margarita: "La Nulidad y Anulabilidad: Su Alcance y Significación”. En Revista de Administración Pública, 104 (1994).

Bloy, René: “Umweltstrafrecht: Geschichte. Dogmatik. Zukunftsperspektiven” (Derecho Penal del Medio Ambiente: Historia. Dogmática. Perspectivas del Futuro). En Juristische Schulung, 37 (1997).

Borowsky, Martin: “La Restricción de los Derechos Fundamentales”. En Revista Española de Derecho Constitucional No 50 (2000).

Brickey, Kathleen F.: "Environmental Crime at the Crossroads: The Intersection of Environmental Law Theory”. En Tulane Law Review, 71 (1996-1997).

Camilo, Javier, y Sessano Goenaga: "La Protección Penal del Medio Ambiente: Peculiaridades de su Tratamiento Jurídico”. En Revista Electrónica de Ciencia Penal y Criminología, 04-11 (2002).

Cancio Meliá, Manuel: "La Responsabilidad del Funcionario por Delitos contra el Medio Ambiente en el Código Penal Español”. En Agustín Jorge Barreiro (dir.), Estudios sobre la Protección del Medio Ambiente en el Ordenamiento Jurídico Español. Granada: Editorial Comares, 2005. 
Cho, Byung-Sun: "El Surgimiento de un Derecho Penal Internacional del Medio Ambiente". En Revista Penal No 8 (2001).

De la Mata Barranco, Norberto: Protección Penal del Medio Ambiente y Accesoriedad Administrativa. Barcelona: Cedecs Editorial S.L., 1996.

Dinamarca, Jaime: "Contaminación en Chile: ¿¿Fallas de la Institucionalidad o Problemas de Gestión?”. Serie en Foco, № 94, Expansiva, Santiago, 2006.

Dripps, Donald A.: "The Liberal Critique of the Harm Principle". En Criminal Justice Ethic, 17 (1998).

“Environmental Crimes" (nota editorial, American Criminal Law Review, 42 (2005).

Esty, Daniel: "Next Generation Environmental Law: A Response to Richard Stewart”. En Capital University Law Review, 29 (2001-2002).

Faure, M., y M. Visser: "How to Punish Environmental Pollution? Some Reflections on Various Models of Criminalization of Environmental Harm”. En European Journal of Criminal Law and Criminal Justice, 4 (1995).

Feijoo Sánchez, Bernardo José: Sanciones para Empresas por Delitos contra el Medio Ambiente. Madrid: Ed. Civitas, 2002.

Feinberg, Joel: Harm to Others. Tomo 1 de la serie The Moral Limits of the Criminal Law. Oxford University Press, 1987.

Fernández Bitterlich, Pedro: Manual de Derecho Ambiental. Santiago: Editorial Jurídica de Chile, 2001.

FerradaNehme: "Informe sobre Institucionalidad Ambiental”. Santiago, junio de 2007. Disponible en: http://www.conama.cl/especiales/1305/articles40867_info InstitucionalidadFN.pdf).

Figueroa, Eugenio, y Domique Hervé: “Evaluación del Marco Institucional y de la Gestión Ambiental en Chile”. Serie en Foco, № 97, Expansiva, Santiago, 2006.

Frase, Richard S.: "Excessive Prison Sentences, Punishment Goals and the Eighth Amendment: Proportionality Relative to What?”. En Minnesota Law Review, 89 (2005).

Habermas, Jürgen: “Acerca de la Lógica de los Problemas de Legitimación”. En Jürgen Habermas, Problemas de Legitimación del Capitalismo Moderno. Buenos Aires: Amorrortu editores, 1986 (2 $2^{\mathrm{a}}$ reimpresión de la $1^{\mathrm{a}}$ edición, 1975). “¿Cómo es Posible la Legitimidad por Vía de Legalidad?” En Jürgen Habermas, Escritos sobre Moralidad y Eticidad. Barcelona: Paidós, 1991.

Hedman, Susan: "Expressive Functions of Criminal Sanctions in Environmental Law". En George Washington Law Review, 59 (1991).

Hefendehl, Roland: “¿Debe Ocuparse el Derecho Penal de Riesgos Futuros? Bienes Jurídicos Colectivos y Delitos de Peligro Abstracto”. En Anales de Derecho de la Universidad de Murcia $\mathrm{N}^{\circ} 19$ (2001).

- Kollective Rechtsgüter im Strafrecht (Bienes jurídicos colectivos en el derecho penal). Köln, Berlin, Bonn, München: Carl Heymanns Verlag KG, 2002.

Hegel, G. W. F.: Principios de la Filosofía del Derecho. Barcelona: Editorial Edhasa, 1988, p. 160).

Heine, Günter: “Accesoriedad Administrativa en el Derecho Penal del Medio Ambiente”. En Anuario de Derecho Penal y Ciencias Penales, tomo 46, Madrid (1993).

Jakobs, Günther: "Das Strafrecht zwischen Funktionalismus und alteuropäischem Prinzipiendenken" (El derecho penal entre el funcionalismo y el pensamiento de principios tradicional europeo). En Zeitschrift für die gesammten Strafrechtswissenschaften, 107 (1995). 
¿Qué Protege el Derecho Penal: Bienes Jurídicos o la Vigencia de la Norma? Mendoza: Ediciones Jurídicas Cuyo, 2001.

Jara Schnettler, Jaime: La Nulidad de Derecho Público ante la Doctrina y la Jurisprudencia. Santiago: Editorial Libromar, 2004.

Jonas, Hans: El Principio Responsabilidad. Barcelona: Editorial Herder, 1995.

Kausel, Teodoro: "Casos Emblemáticos para la Institucionalidad Ambiental Chilena”. Serie en Foco, $N^{\circ}$ 90, Expansiva, Santiago, 2006.

Kuhlen, Lothar: "Umweltstrafrecht - auf der Suche nach einer neuen Dogmatik" ("Derecho penal del medio ambiente - a la búsqueda de una nueva dogmática"). En Zeitschrift für die gesamten Strafrechtswissenschaften 105 (1993).

Lagodny, Otto: Das Strafrecht vor den Schranken der Grundrechte ("El derecho penal ante los límites de los derechos fundamentales”). Tübingen: J.C.B. Mohr (Paul Siebeck), 1996.

Lamas, Jaime y Carlos Chávez: "El Sistema de Evaluación de Impacto Ambiental. Análisis del Diseño de Fiscalización y su Cumplimiento en la Región del Bío-Bío”. En Estudios Públicos, 105 (2007).

Larraín, Sara: "Desafíos Ambientales del Desarrollo Nacional. Evaluación Desempeño 1997-2006 y Propuesta Institucional”. Serie en Foco, № 92, Expansiva, Santiago, 2006.

Lavín, Julio: “El SEIA: Visión Crítica a 10 Años de su Vigencia”. Serie en Foco, № 95, Expansiva, Santiago, 2006.

Lazarus, Richard L.: "Assimilating Environmental Protection into Legal Rules and the Problem with Environmental Crime”. En Loyola of Los Angeles Law Review, 27 (1994).

"Meeting the Demands of Integration in the Evolution of Environmental Law: Reforming Environmental Criminal Law". En The Georgetown Law Journal, 83 (1995a).

- "The Reality of Environmental Law in the Prosecution of Environmental Crimes: A Reply to the Department of Justice”. En Georgetown Law Journal, 83 (1995b).

- "Congressional Descent: The Demise of Deliberative Democracy in Environmental Law”. En The Georgetown Law Journal, 94 (2006).

Lin, Albert C.: "The Unifying Role of Harm in Environmental Law". En Wisconsin Law Review (2006).

López, Ganni: "Propuesta de una Nueva Institucionalidad para la Fiscalización Ambiental de la Industria”. Serie en Foco, No 96, Expansiva, Santiago, 2006.

Mañalich, Juan Pablo: "La Protección del Medio Ambiente bajo el Nuevo Código Penal de Puerto Rico”. En Revista Jurídica de Puerto Rico, 75 (2006).

“La Pena como Retribución”. En Estudios Públicos No 108 (2007).

Matus Acuña, Jean Pierre (ed.): Derecho Penal del Medio Ambiente. Estudios y Propuesta para un Nuevo Derecho Penal Ambiental Chileno. Santiago: Editorial Jurídica de Chile, 2004.

Matus Acuña, Jean Pierre, Marcos Orellana Cruz, Marcelo Castillo Sánchez, María Cecilia Ramírez Guzmán: “Análisis Dogmático del Derecho Penal Ambiental Chileno a la Luz del Derecho Comparado y las Obligaciones Contraídas por Chile en el Ámbito del Derecho Internacional. Conclusiones y Propuesta Legislativa Fundada para una Nueva Protección Penal del Medio Ambiente en Chile”. En Revista Ius et Praxis (Talca), Año 9 No 2 (2003). 
Matus A., Jean Pierre, María Cecilia Ramírez G., Marcelo Castillo: "Informe sobre el Derecho Penal Ambiental en el Derecho Comparado de Tradición Continental”. En Revista Gaceta Jurídica № 260 (2002).

Mendoza Buero, Blanca: “El Delito Ecológico: Configuración Típica, Estructuras y Modelos de Tipificación” En Agustín Jorge Barreiro (dir.), Estudios sobre la Protección del Medio Ambiente en el Ordenamiento Jurídico Español. Granada: Editorial Comares, 2005.

Mendoza Calderón, Silvia: "La Protección Penal del Medio Ambiente en Alemania, Italia, Francia y España: Estudio de Derecho Penal Comparado”. En Revista Electrónica de Ciencias Jurídicas, 02.03/05.

Montesquieu: Del Espíritu de las Leyes. Madrid: Editorial Tecnos, 1972.

Müller-Tuckfeld, Christian: "Ensayo para la Abolición del Derecho Penal del Medio Ambiente”. En (varios autores), La Insostenible Situación del Derecho Penal. Granada: Ed. Comares, 2000.

Organización de Cooperación y Desarrollo Económicos y la Comisión Económica para América Latina y el Caribe: Evaluaciones del desempeño ambiental de la OCDEChile, 2005. Disponible en: http://www.direcon.cl/documentos/OCDE/ OCDE_EVALUACION_MEDIOAMBIENTAL.pdf).

Otto, Harro: "Grundsäztliche Problemstellungen des Umweltstrafrechts" ("Problemas fundamentales del derecho penal del medio ambiente"). En Jura (1991).

“Das neue Umweltsstrafrecht” (El nuevo derecho penal del medio ambiente). En Jura (1995).

Plater, Zygmunt J. B.: "From the Beginning, a Fundamental Shift of Paradigms: A Theory and Short History of Environmental Law". En Loyola University of Los Angeles Law Review, 27 (1993-1994).

Queralt Jiménez, Joan: Derecho Penal Español. Parte Especial. Barcelona: Atelier, 2002.

Ransiek, Andreas: “Comentario a los §§ 324-330-a StGB”. En Urs Kindhäuser, Ulfried Neumann y Hans-Ulrich Paeffgen (eds.), NomosKommentar- Strafgesetzbuch. Tomo II. Baden-Baden: Nomos, Verlag, 2a ed., 2005.

Rengier, Rudolf: "Zur Bestimmung und Bedeutung der Rechtsgüter im Umweltstrafrecht” (Acerca de la determinación y significado de los bienes jurídicos en el derecho penal del medio ambiente). En Neue Juristische Wochenschrift (1990).

Roxin, Claus: Strafrecht. Allgemeiner Teil (Derecho Penal. Parte General), Tomo I. München: C.H. Beck'sche Verlag, 3ª ed., 1997. [Versión en español de la $1^{\text {a }}$ ed. bajo ese título en Editorial Civitas, Madrid, 1997.]

Rudolphi, Hans-Joachim: "Primat des Strafrechts im Umweltschutz?” (¿Primado del derecho penal en la protección del medio ambiente?). En Neue Zeitschrift für Strafrecht, 1984.

Santa María Pastor, Juan Alfonso: La Nulidad de Pleno Derecho de los Actos Administrativos. Madrid: Instituto de Estudios Administrativos, 1972.

Schiffer, Lois J. y James Simon: "The Reality of Prosecuting Environmental Criminals: A Response to Professor Lazarus”. En Georgetown Law Journal, 83 (1995).

Schroeder, Christopher H.: "Cool Analysis Versus Moral Outrage in the Development of Federal Environmental Criminal Law”. En William \& Mary Law Review, 35, (1993).

Schünemann, Bernd: “Zur Dogmatik und Kriminalpolitik des Umweltstrafrechts” (Sobre la dogmática y la política criminal del derecho penal del medio ambiente). En Kurt 
Schmoller y otros, Festschrift für Otto Trifterer. Wien, New York: Spinger Verlag, 1996. [Versión en español en Schünemann, Bernd: Temas Actuales y Permanentes del Derecho Penal después del Milenio. Madrid: Editorial Tecnos, 2002.]

Schünemann, Bernd: Temas Actuales y Permanentes del Derecho Penal después del Milenio. Madrid: Editorial Tecnos, 2002.

Seher, Gerhard: Liberalismus und Strafe. Zur Strafreechtsphilosophie von Joel Feinberg (“Liberalismo y pena. Acerca de la filosofía del derecho penal de Joel Feinberg”). Berlin: Duncker \& Humblot, 2000.

Silva Sánchez, Jesús María: Delitos contra el Medio Ambiente. Valencia: Ed. Tirant Lo Blanch, 1999a.

La Expansión del Derecho Penal. Aspectos de la Política Criminal en las Sociedades Industriales. Madrid: Editorial Civitas, 1999b.

Stächelin, Gregor: Strafgesetzgebung im Verfassungsstaat ("Legislación penal en el Estado constitucional”). Berlin: Duncker \& Humblot, 1998.

Steindorf, Joachim: “Observación Preliminar a los §§ 324-330-a StGB”. En Burkhard v. Jähnke, Heinrich Wilhelm Laufhutley Walter Odersky (eds.), StrafgesetzbuchLeipziger Komentar. Berlin: de Gruyter Recht, 11ª ed., 2005.

Stewart, Richard: “A New Generation of Environmental Regulation?”. En Capital University Law Review, 29 (2001-2002).

Tiedemann, Klaus, y Urs Kindhäuser: "Umweltstrafrecht - Bewährung oder Reform?” (“Derecho penal del medio ambiente - ¿Conservación o reforma?”). En Neue Zeitschrift für Strafrecht (1988).

Vergara, Javier: "Criterios a Tener en Cuenta para la Discusión de una Política y una Institucionalidad Ambiental en Chile". Serie en Foco, No 93, Expansiva, Santiago, 2006.

Von Hirsch, Andrew: Censurar y Castigar. Madrid: Editorial Trotta, 1998.

White, Peter C.: "Environmental Justice since Hammurabi: From Assigning Risk 'Eyefor-Eye' to Modern Day Application of the Responsible Corporate Officer Doctrine”. En William and Mary Environmental Law and Policy Review, 29 (2005). 